\title{
Form Follows Function in Community Rituals in North China: Temples and Temple Festivals in Jiacun Village
}

\author{
Xiaohuan Zhao
}

Citation: Zhao, Xiaohuan. 2021.

Form Follows Function in Community Rituals in North China: Temples and Temple Festivals in Jiacun Village. Religions 12: 1105. https://doi.org/10.3390/rel12121105

Academic Editor: Yuet Keung Lo

Received: 27 October 2021

Accepted: 7 December 2021

Published: 15 December 2021

Publisher's Note: MDPI stays neutral with regard to jurisdictional claims in published maps and institutional affiliations.

Copyright: (C) 2021 by the author. Licensee MDPI, Basel, Switzerland. This article is an open access article distributed under the terms and conditions of the Creative Commons Attribution (CC BY) license (https:// creativecommons.org/licenses/by/ $4.0 /)$.
Faculty of Arts and Social Sciences, The University of Sydney, Sydney, NSW 2006, Australia; xiaohuan.zhao@sydney.edu.au

\begin{abstract}
Yingshen saishe or saishe is a general name for all types of temple festivals held to offer sacrifices to deities of local communities. With its roots traceable to ancient shamanic beliefs and practices, saishe demonstrates itself as a closely integrated form of religious ritual performance and musical/theatrical performance and proves to be instrumental in the development of Chinese theatre from ritual to drama. Based on my fieldwork on Jiacun Double-Fourth Temple Festival in May 2016, this paper offers a close examination of Jiacun temple culture and temple theatre with focus on the religious ritual performance and musical/theatrical entertainment presented during the festival. In so doing, this paper provides an enhanced understanding of the highly dynamic, interactive relationships between temple and theatre and between efficacy and entertainment.
\end{abstract}

Keywords: ritual; temple festival; temple theatre; Jiacun Double-Fourth Temple Festival; the Primordial Sovereign of the Morning Clouds (Bixia yuanjun); Shangdang

\section{Introduction}

Yingshen saishe 迎神賽社 or saishe 賽社 is a general name for all types of temple festivals and temple fairs (miaohui 廟會) held to offer sacrifices to deities of local communities and to entertain them with musical and theatrical performance. Also known as shehuo 社火, saishe is a living tradition that originated from an ancient community ritual known as 'spring prayer and autumn thanksgiving' (chunqi qiubao 春祈秋報) (Tanaka 1998, pp. 37-40; Zhu 2018, pp. 25-32), which itself developed from the earlier 'Three Big Sacrifices', namely, the rain-seeking ritual of $y u$ 霉, the year-end thanksgiving ritual of $z h a / l a$ 蜡/臘 and particularly the exorcism ritual of nuo 儺 (Zhao 1988, pp. 184-89; Yang 1992; Han 1992; Han et al. 1999; Zhou 2016, pp. 2-9). The word sai 賽 in saishe is written in early Chinese texts as sai 塞, meaning 'offering sacrifices in gratitude to deities' (e.g., Shiji suoyin 9.14b; Lunheng 24.17a), whereas she 社 in saishe is a polysemous word that may refer to the Lord of the Soil (Liji 25.221a; Shuowen jiezi 1.6a-b), a shrine to the Lord of the Soil (Chunqiu zuozhuan 11.85c, $11.86 \mathrm{c}$ ), and a ritual community or a community worship association bound up with the Lord of the Soil (Chunqiu zuozhuan 51.408b; Liji 25.221b). As for the meaning of huo 火 in shehuo, no consensus seems to have been reached among scholars: some of them trace it to a Shang (ca. 1600-1046 BC) oracle-bone script that has been identified as liao 燎, referring to the ritual of 'burning sacrifice in the shrine to the Lord of the Soil' (Chao 1995, p. 72n); some treat it as a phonetic loan character of huo 夥, meaning 'crowd/multitude' as in the Yilin huikao 藝林匯 考 or Collected Evidential Studies in the Forest of Art (Yilin huikao 36.2a), from which is derived the meaning of 'lively/bustling' (honghuo 紅火/huobao 火爆) (Zhao 1999, p. 134); some interpret it as referring to the ancient ritual of 'burning sacrifices on firewood and offering them up to heavenly deities' (chai 紫) (Wang and Lü 2007, p. 61). While all of these interpretations make sense in one way or another, a more plausible etymological explanation of huo in shehuo, in our view, lies in nuo exorcism, in which wu 巫-shaman priests/exorcists hold torches made from reeds to expel diseases and demons as denoted by jue 爝 and guan 爟 (Shuowen jiezi 10a.25b, 10a.26a-b; see also Lüshi chunqiu 
14.5a). Significantly, this ancient form of nuo exorcism can still be seen today in Nanfeng 南 豐, Jiangxi province (Ji 1998).

The annual ritual of 'offering prayers in spring and giving thanks in autumn' (chunqi qiubao) emerged in the Zhou dynasty (1045-256 BC) (Maoshi 19.333a-335b), ${ }^{1}$ evolved into a community festival in the Han dynasty (206 BC-AD 220) (Baihu tong 2.4a; Hanshu 24.8a) and integrated with nuo and baixi 百戲 (lit. 'hundred entertainments') in the Song dynasty into a variety show of ritual, musical and theatrical performances known as shehuo (Dongjing menghua lu 8.758; Xihu laoren fansheng lu 1.10-12; see also Zhang 2014, p. 62; Zhao 1999, pp. 140-41). Musical and theatrical entertainments ( $x i$ 戲) are not mere appendages of but integral to rituals of offering sacrifices to deities (sai) during community or temple festivals, hence saixi 賽戲 (temple theatre). Temple theatre demonstrates itself as a closely integrated form of religious ritual performance and musical and theatrical entertainment and proves to be instrumental in the development of Chinese theatre from ritual to drama (Zhao 2022a, 2002b).

This paper attempts an ethnomethodologically informed study of saishe with focus on the sai ritual and xi performance presented during temple festivals in Jiacun 賈村 village. Originally called Nanjiacun 南賈村, Jiacun is located about three kilometres southwest of the urban centre of Lucheng 沙城 in southeastern Shanxi province. Historically under the jurisdiction of Shangdang 上黨 Commandery, Southeast Shanxi covers roughly the area of modern-day Changzhi 長治, a prefecture-level city that comprises four districts and eight counties including Lucheng, Tunliu 屯留, Zhangzi 長子 and Pingshun 平順. Among various Shangdang village festivals, the most famous and representative is perhaps Jiacun temple festival, which is widely acclaimed as the 'number one folk shehuo in North China' (Qu 2006; Wang 2006) for its long, well-documented history and also for its highly developed temple culture and deep-rooted theatrical tradition. Based on my fieldwork in Jiacun village in May 2016, I examine the Double-Fourth Temple Festival (Siyuesi miaosai 四月四廟賽) held to celebrate the birthday of the Primordial Sovereign of the Morning Clouds (Bixia yuanjun 碧霞元君). I focus on the religious ritual performance and musical and theatrical entertainment presented during the festival with a view to presenting the highly dynamic, interactive relationships between temple and theatre and between efficacy and entertainment in a real-life setting.

\section{Literature Review}

Much research has been conducted on local folk religions in rural North China in the past two decades. Somewhat different as these studies are in geographic focus and temporal scope, they tend towards adopting an ethnographic bottom-up approach, aligned with fieldwork-informed case studies, to cultic worship, ritual performance, community participation and socioreligious organisation, demonstrating a shift of focus in religious and cultural studies from elite culture to popular culture and from the organised religion to local cults, cult festivals and cult associations.

Most notable among them are Overmyer (2009) and Johnson (2009), both drawing on a wide range of sources from earlier studies in Chinese, Japanese and Western languages to dynastic and local histories to legendary and anecdotal accounts to fieldwork reports by local scholars to newly discovered, annotated liturgical texts. Significantly, Overmyer (2009, pp. 4-5) regards Chinese local religion as 'the mainstream of Chinese religion', which, he argues convincingly, 'has always been community-based, inclusive and nonsectarian' and which, he notices, has long been 'ignored or disparaged by both Chinese and Western scholars as a confused congeries of diffuse superstitions, a residual category without any integrity of its own, discussed only in relation to the better-known traditions of Confucianism, Daoism and Buddhism'. While both of them have focus on community rituals and festivals in North China, Overmyer (2009) aims to provide a comprehensive survey of the structure, organisation and institution of local community religions in the vast rural areas of Hebei, Henan, Shandong and Shanxi provinces in the twentieth century, thus covering a much broader geographic and thematic scope than Johnson (2009), who, in 
contrast, is primarily concerned with 'temple-based liturgical rituals' or 'rituals in honor of the birthday of a local god' in pre-communist Shanxi that 'were very heart of the symbolic culture of the countryside, the bedrock of mainstream Chinese popular religion' (Johnson 2009, p. 145).

Particularly noteworthy is his study of 'The Great Temple Festivals of Southeastern Shanxi' (Johnson 2009, pp. 177-320). Selected for his case study are three temples-namely, the Temple of the Divine Mother of the Ninth Heaven (Jiutian shengmu miao九天聖母廟) in Pingshun county (Johnson 2009, pp. 187-234), the Houyi 后森. Temple on Mount Longquan 龍泉 (Johnson 2009, pp. 235-82) and the Houyi Temple of Big West Gate (Daxiguan 大西關), both in Zhangzi county (Johnson 2009, pp. 283-301). Through his fine-grained description and analysis, Johnson offers an excellent example of historical-empirical enquiries into village festivals in the Shangdang region.

Shangdang has attracted much attention of scholars of Chinese popular religion, culture and theatre since the 1980s when more than twenty liturgical manuscripts from the late imperial period were discovered in this area (Yang 2000; Yang 2006; Johnson 2009, pp. 180-84). Among them are The Transmitted Records for Welcoming the Deities and Worshipping the Lord of Soil, with Forty Melodies in [Twenty-Eight] Keys (Yingshen saishe lijie chuanbu sishi qu [ershiba] gongdiao 迎神賽社禮節傅簿四十曲 [二十八] 宮調, hereafter Lijie chuanbu), which is alternatively titled The Diagram of the Musical Asterisms of the Zhou Dynasty (Zhou yuexing tu 周樂星圖) (Du 2011b, pp. 236-83); The Diagram of the Musical Asterisms of the Tang Dynasty (Tang yuexing tu 唐樂星圖) (Li 1993a; Yang 2000, pp. 419-98); The Exemplary Texts for Offering Sacrifices during Temple Festivals with a Catalogue of Melodies for Offering Cups (Yingshen saishe jisi wenfan ji gongzhan qumu 迎神賽社祭祀文範及供盄曲 目, hereafter Jisi wenfan) (Han et al. 1991a); and Manuscripts from the Mound of the Locust Emperor for the Eight Big Village Worship Associations (Huanghuanggang badashe chaoben 蝗皇 崗八大社抄本, hereafter Huanghuanggang). ${ }^{2}$ They were compiled by and for ritualists as liturgical manuals and are therefore extremely valuable for the study of folk religion and temple theatre in Shangdang.

There is evidence that temple festivals prevailed in the Shangdang area during the period of transition from the Northern Song (960-1127) to the Jurchen Jin dynasty (11151234). ${ }^{3}$ Temple festivals that had been held for centuries since then were banned during the Anti-Japanese War (1937-1945). The ban continued to be placed on them into the Maoist era (1949-1976) until after China started to reform and open up to the outside world in the 1980s. During the half-century ban, many ritualists and village elders who had been personally involved in performing or organising temple festivals died without passing on their knowledge and experience to younger generations. Had it not been for the discovery of these liturgical texts, it would have been hardly possible to revive and reconstruct Shangdang temple festival and temple theatre.

The newly discovered liturgical texts attracted immediate attention from local scholars. Some of them such as Han Sheng 寒聲, Li Tiansheng 李天生 and Yang Mengheng 楊孟衡 were also engaged in searching for and collecting these materials and editing them into readable form for research. Numerous punctuated, annotated ritual manuscripts, journal articles, book chapters and scholarly monographs have been published by local scholars since then as shown in Han et al. (1987a, 1987b, 1999), Li (1993b, 1993c), Zhang and Pu (1993), Yang (1992, 1997a, 2006), Feng (2000), Du (2011a, 2011b) and Wang (2012). These works are mostly ethnographically oriented and grounded in participant observation, personal interviews with locals, memories of old villagers, temple stone stelae inscriptions and liturgical manuscripts. Most noteworthy among them are Du (2011a, 2011b) and Wang (2012). The former, compiled by Du Tonghai 杜同海 (a local farmer-scholar and ritualist), is the most comprehensive collection available so far of primary sources on temples and temple festivals in Jiacun; the latter, written by Wang Xuefeng 王學鋒, a native of Shanxi, based on his PhD thesis completed in 2007 at the Chinese National Academy of Arts, is the first and also the hitherto most systematic study of Jiacun village temple festivals. 
Of particular interest to the present study is that Wang (2012) provides a historical survey of the restoration, revival and reform of Jiacun temple festivals over a period of ten years from 1996 to 2006, followed by a close examination of various factors contributing to the modifications made to the ritual and theatrical performances over these years with special reference to the 'large-scale re-enactments of ancient temple festivals' (fanggu biaoyan dasai 仿古表演大賽) held for 'outsiders', respectively, in May 1997 and August 2006 (Wang 2007, p. 69). ${ }^{4}$ The outsiders are local government officials, scholars, journalists and tourists, and they are so called because they are people from outside the local worship community or ritual association. Such re-enactments of temple festivals performed for outsiders, as commonly seen in the officially or semi-officially sponsored presentation of traditional performing arts and religious rituals in contemporary China (Mackerras 2011; Bruckermann 2015), are a double-edge sword: they help enhance the reputation of Jiacun as a centre for village temple festivals in Shangdang but at the same time inevitably spoil festival spontaneity and religiosity (Wang 2011; Yao 2019).

It is now difficult to pinpoint the distinction between what is original and what is not in Jiacun temple festivals, nor is it important or necessary, actually. What matters is that temple festivals, albeit reconstructed and modified in corporeal form, remain at the very heart of the spiritual life of village people, and more importantly, they still maintain their original dual functioning as a religious ceremony to offer sacrifices to local deities and as a sociocultural tie to bind villagers as a community (Du 2016; Song 2016a, ). A case in point is the Double-Fourth Temple Festival in Jiacun. Arguably the oldest surviving village festival in Shangdang, the Double-Fourth Temple Festival retains more of the original form and function of shehuo than any other village festivals in southeastern Shanxi, hence its reputation as 'the number one folk shehuo in North China'.

\section{Temples and Shrines in Jiacun}

I had read a lot about Shangdang saishe but had not had an opportunity to conduct observations there until early May 2016, when I was invited to give a seminar talk on ritual origins of Chinese theatre at Changzhi University as a Guest Professor-an honorary title bestowed on me by Professor Ru Wenming 茹文明, President of Changzhi University. After the seminar, I carried out the long-awaited fieldwork along with Professors Che Wenming 車文明, Yao Chunmin 姚春敏, Wang Luwei 王潞偉 and several other colleagues from Shanxi Normal University, where I serve as a Distinguished Overseas Professor of Chinese Drama and Theatre. Our fieldwork on Jiacun shehuo was very fruitful thanks to the arrangement of the Changzhi University's Research Institute of Shangdang Saishe Culture. In Jiacun, we visited temples and shrines, observed the famous Double-Fourth Temple Festival and also interviewed worship community heads and elders, and ritual specialists and organisers. These people are all farmer villagers rather than professional ritualists who are engaged in ritual performance as their main paid occupation.

Jiacun village covers a land area of $5267 \mathrm{mu}$ 楠 (approx. 352 hectares), which is largely a flat plain suitable for farming except for two small hills, the Phoenix Hill (Fenghuangshan 鳳凰山) and the Shadowless Mound (Wuyinggang 無影崗), which are located on its western and southern borders, respectively. Jiacun has a population of 2870 in 785 registered households ( $h u$ 戶) and is divided into eleven village groups as of 2016. The villagers are all Han Chinese. Dominant among the fifty-five family names in Jiacun are Wang 王, Cao 曹, Zhang 張, Song 朱, Niu 牛, $\mathrm{Li}$ 李 and Cui 崔. These six big families account for more than $60 \%$ of the total households in the village and enjoy a preponderant influence in village affairs and temple festivals.

Jiacun is one of the thirteen villages in the local government area of Zhaidian 翟店 township. To the northwest of Jiacun are Heyi 河移, Beishe 北舍 and Nanshe 南舍, to the west Chongdao 崇道, to the southwest Xiaotiangong, Dongtiangong 東天貢, Xitiangong 西 天貢, Nantiangong 南天貢 and Guocun 郭村, to the south Kangcheng 姜城 ${ }^{5}$ and Zhaishang 寨上, and to the southeast Zhaidian. All of them, with the exception of the northwesternmost Heyi and the southwesternmost Nantiangong and Guocun, are members of the 
aforementioned Eight Big Village Worship Associations. Each member village has its own village temple festivals to celebrate and has also a shared responsibility with other member villages for organising and holding the Festival of the Eight Big Worship Associationsnamely, the Festival on the Mound of the Emperor of Locusts (Huanghuanggang sai 蝗皇崗 賽) (Du 2011a, pp. 242-43).

Jiacun is an ancient village noted for its deep-rooted temple culture. 'There first came the Palace of the Morning Clouds (Bixia gong 碧霞宮), then Lucheng county,' as a popular local saying goes. Jiacun alone has three big local community worship associations (dashe 大社)—namely, the Front Community (qianshe 前社), the Middle Community (zhongshe 中 社) and the Rear Community (houshe 後社) — which are further divided into eight small communities (xiaoshe 小社). The three big communities are each headed by a Community Head (sheshou 社首) who has overall responsibility for managing and maintaining temples and shrines in his domain and collaborating with the other worship communities in organising village temple festivals. To each temple or shrine is allocated approximately one hundred $m u$ (equiv. 6.67 hectare) of community-owned agricultural land (sheitan 社田) to cover the costs of routine operation and maintenance and village festivals.

The village boasts seventeen temples and shrines: the Palace of the Morning Clouds (Bixia gong), the Temple of the Jade Emperor (Yuhuang miao 玉皇廟) ${ }^{6}$ (Figure 1$),{ }^{7}$ the Palace of the Three Primordials (Sanyuan gong 三元宮) (Figure 2), ${ }_{1}^{8}$ the Pavilion of Guanyin (Guanyin ge 觀音閣), the Hall of the Three Great Bodhisattvas (Sandashi tang 三大士堂), ${ }^{9}$ the Temple of Emperor Guan (Guandi miao 關帝廟) (Figures 3 and 4), the Temple of the Patriarch (Zushi miao祖師廟), also called the Temple of the Perfected Warrior (Zhenwu miao 真武廟) (Figures 5 and 6), the Hall of White Robe (Baiyi tang 白衣堂), ${ }^{10}$ the Hall of the Cui Family (Cuijia tang 崔家堂), ${ }^{11}$ the Shrine of the Earth God (Tudi miao 土地廟), the Pavilion of the God of Literature and Culture (Wenchang ge 文昌閣), the Hall of the Buddha (Fodian 佛殿), the Shrine of Patriarch Lü (Lüzu an 呂祖庵) and the Shrine of the Bald-Headed Grandma (Tunainai miao 秃奶奶廟) (Figure 7), ${ }^{12}$ in addition to three small shrines to the Five Paths (Wudao miao 五道廟). ${ }^{13}$

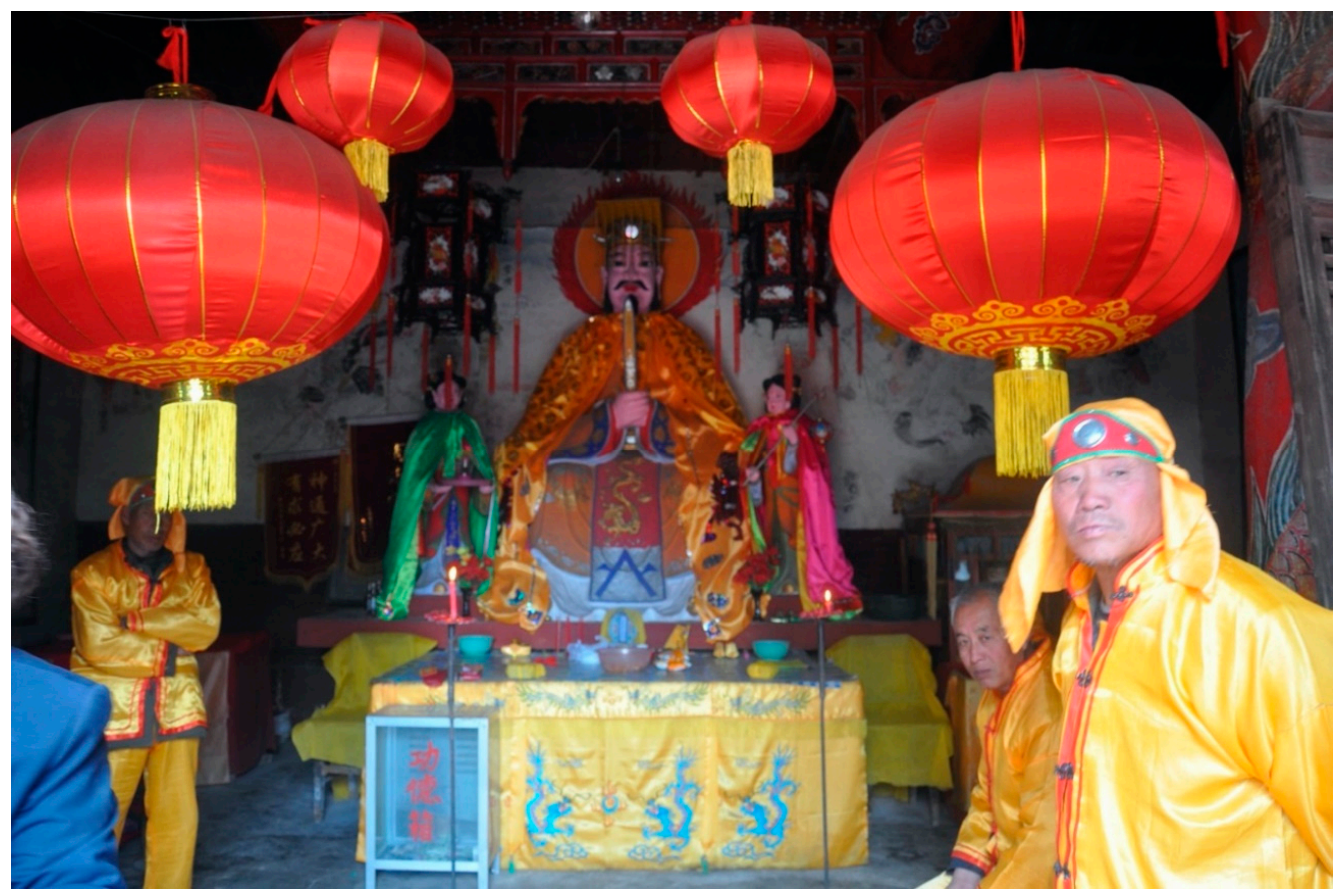

Figure 1. Main Hall of Jade Emperor Temple. 


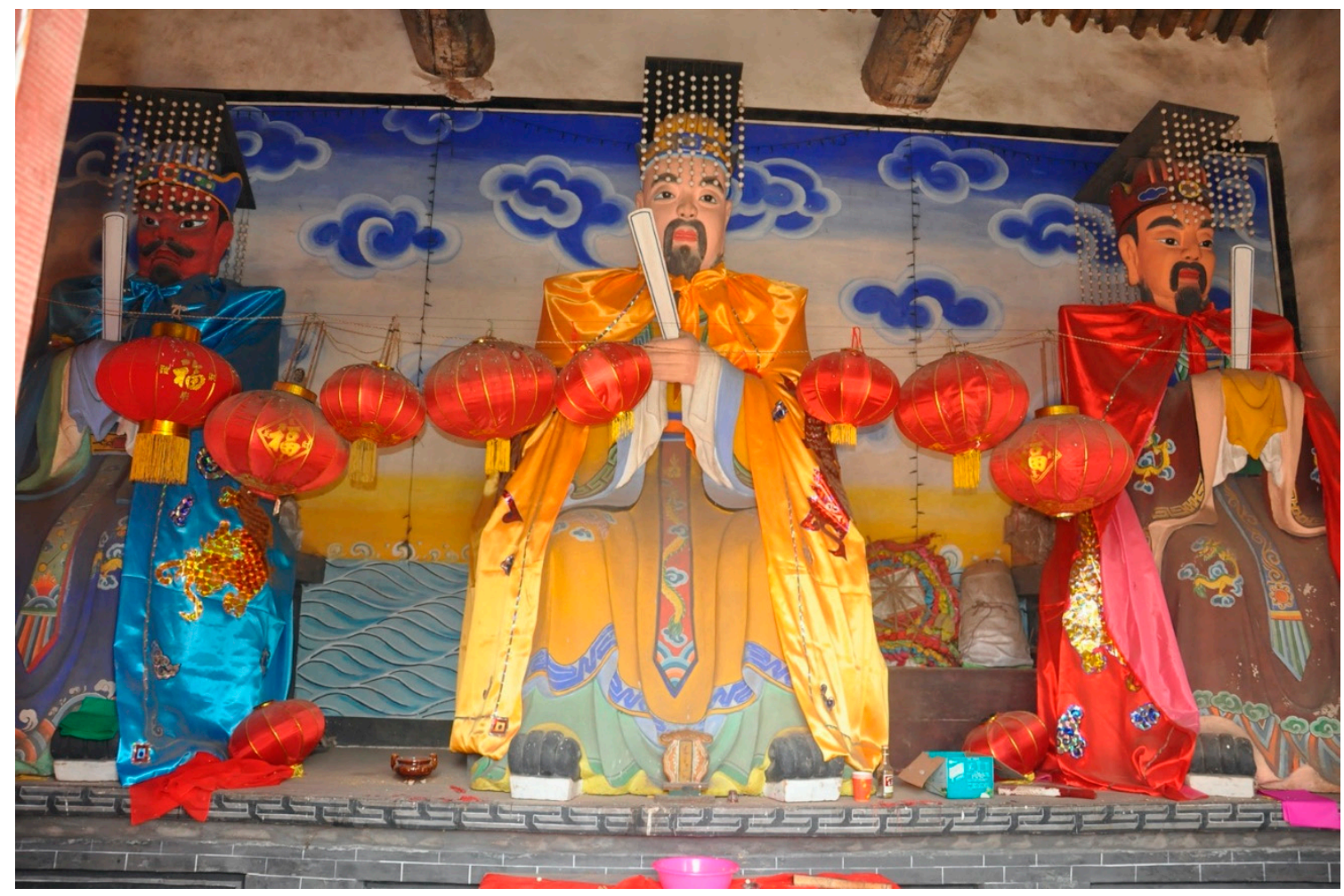

Figure 2. Three Primordials: Tianguan flanked by Diguan (right) and Shuiguan (left).

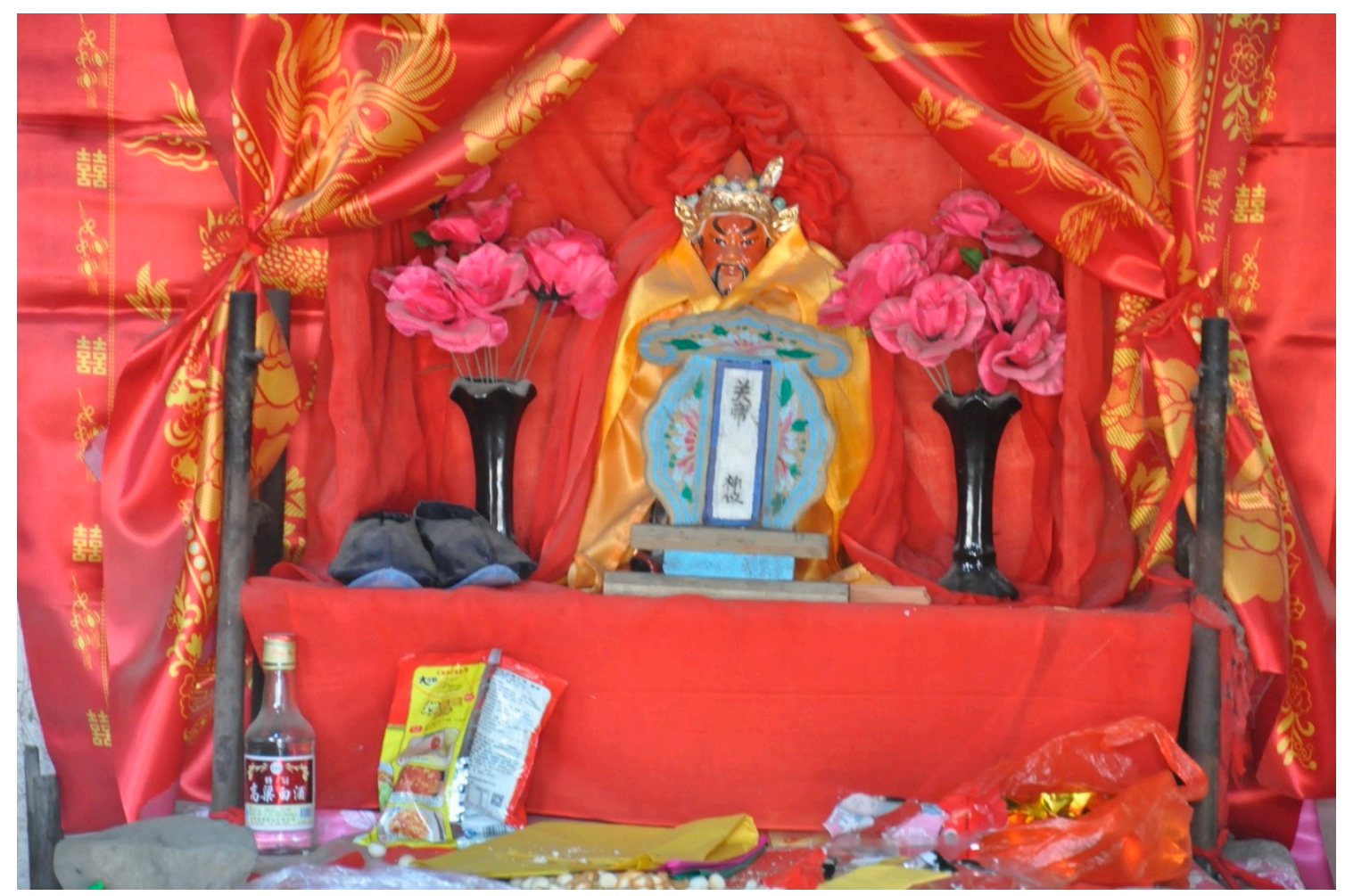

Figure 3. Statue and Spirit Tablet of Lord Guan Enshrined in the Sacrificial Hall of Emperor Guan Temple. 


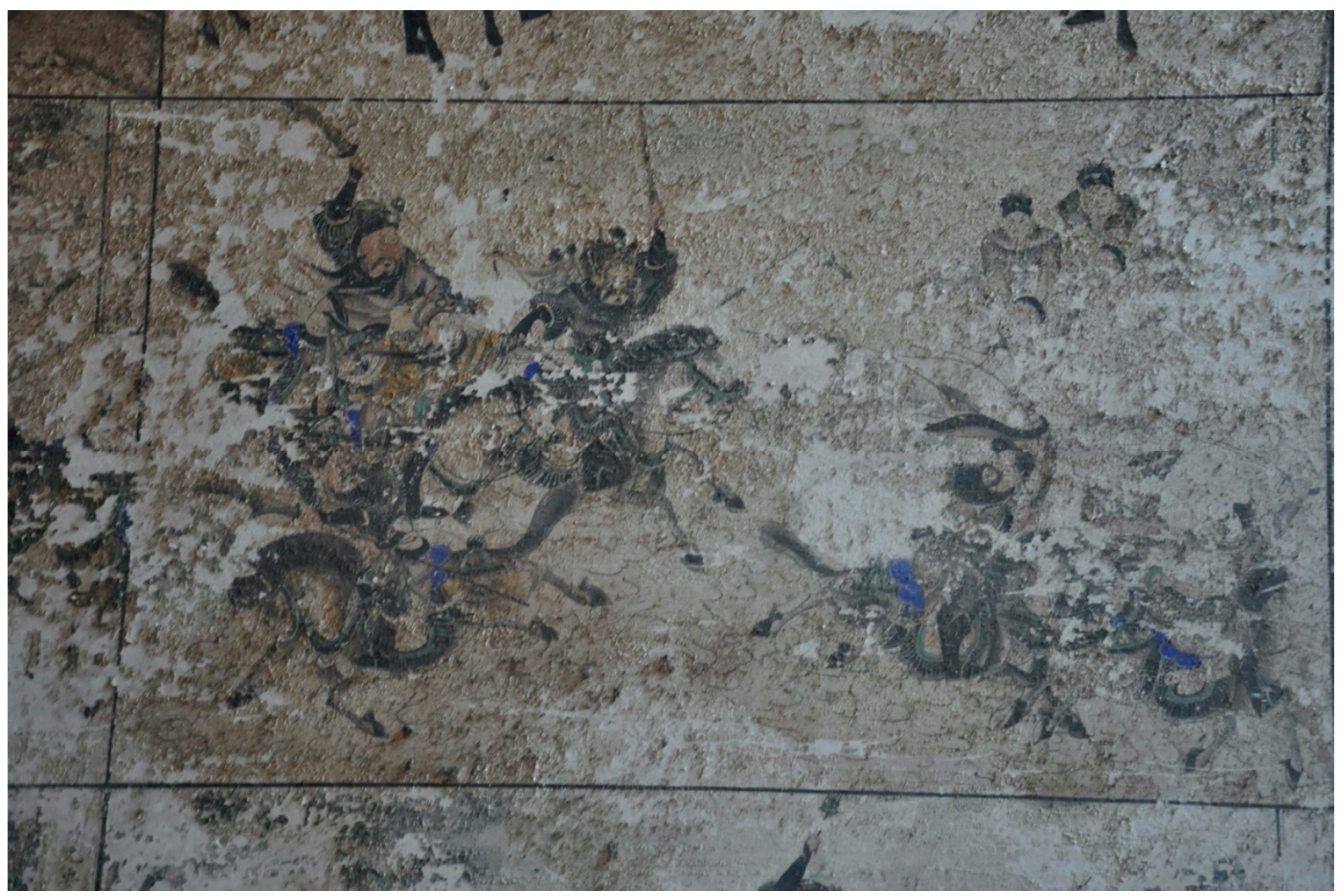

Figure 4. A Section of the Mural Depicting Lord Guan Crossing Five Passes and Decapitating Six Generals (Guo wugan zhan liujiang 過五關斬六將) on the Northern Wall of the Sacrificial Hall of Emperor Guan Temple.

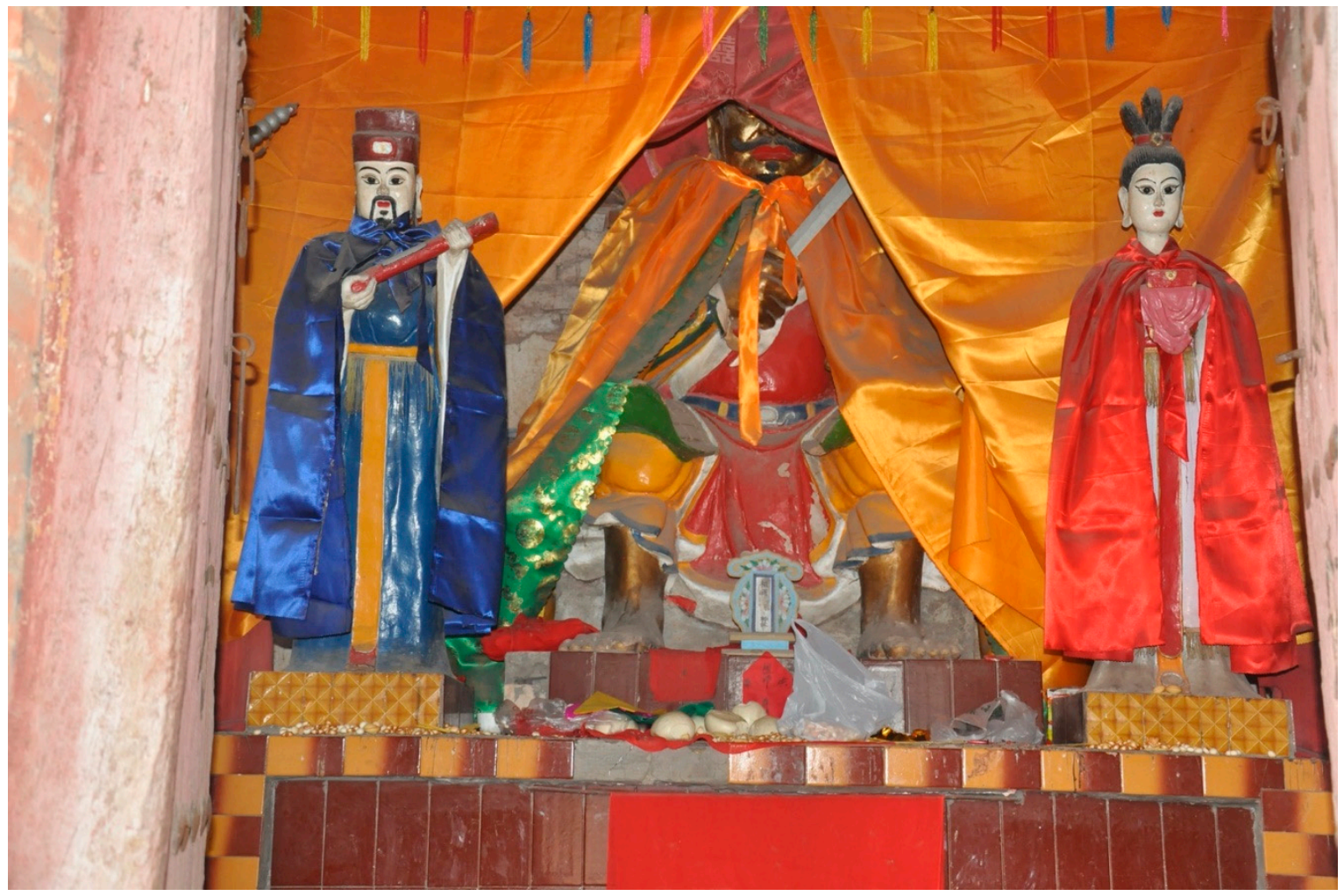

Figure 5. Statue of the Patriarch. 


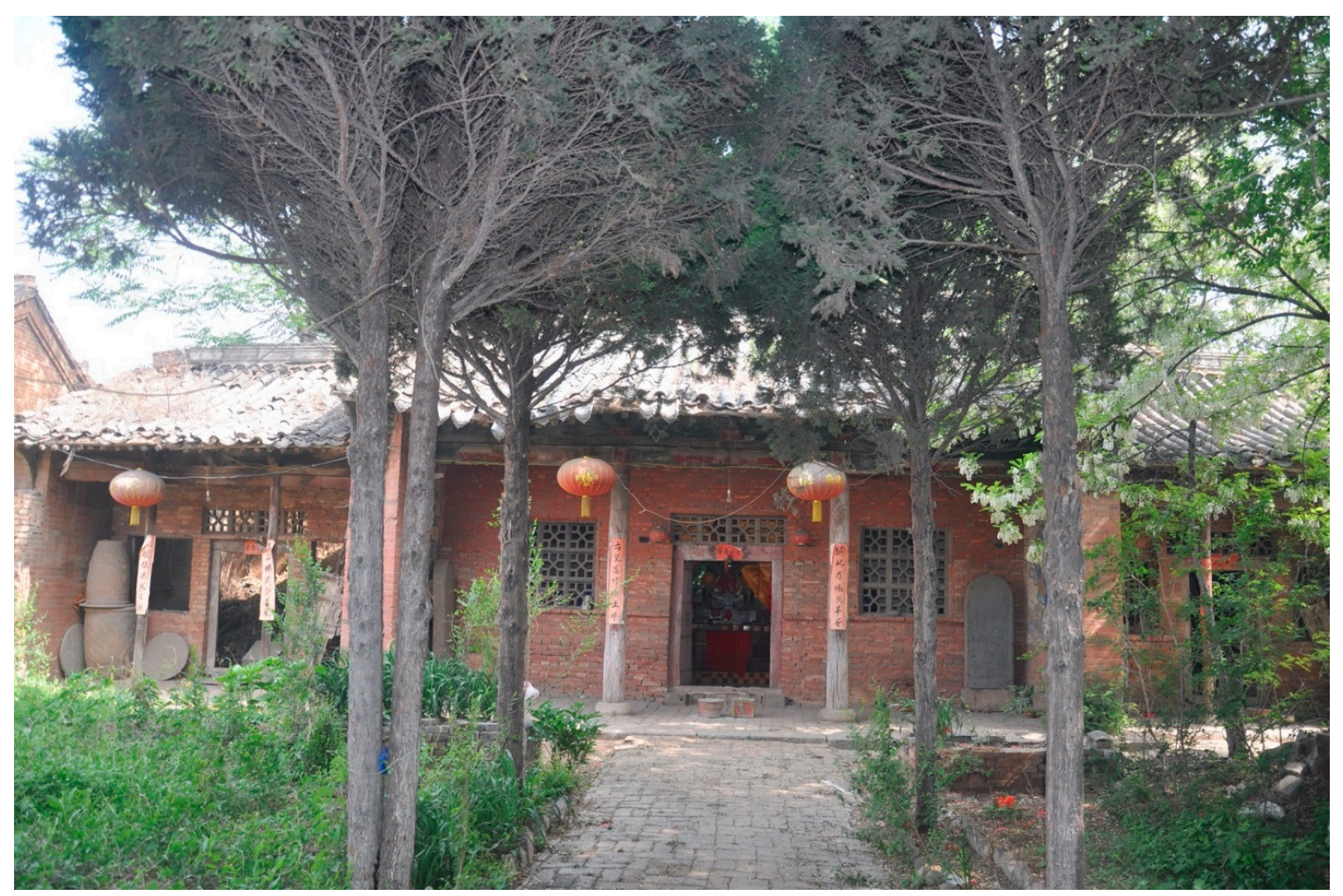

Figure 6. Patriarch Temple Viewed from Outside.

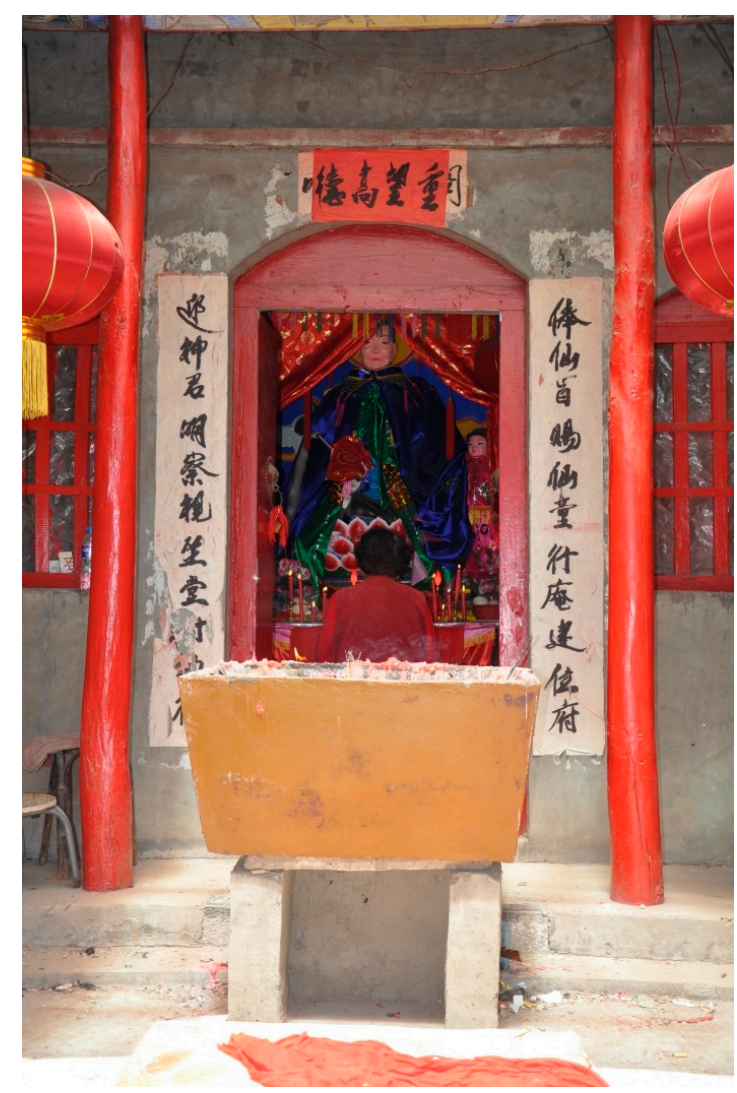

Figure 7. Shrine of the Bald-Headed Grandma. 
The most prominent of them is Bixia gong, which occupies a central position—spatially and spiritually-in Jiacun (Figure 8).

These temples and shrines may be classified into four groups according to their religious origin or orientation, as shown below in Table 1:

Table 1. Temples and Shrines in Jiacun.

\begin{tabular}{|c|c|c|c|c|c|c|c|}
\hline \multirow[b]{2}{*}{ Temple/Shrine } & \multicolumn{4}{|c|}{ Religious Orientation } & \multicolumn{2}{|l|}{ History } & \multirow{2}{*}{$\begin{array}{l}\text { Preservation } \\
\text { Status }^{14}\end{array}$} \\
\hline & Buddhism & Confucianism & Daoism & $\begin{array}{l}\text { Folk } \\
\text { Belief }\end{array}$ & $\begin{array}{l}\text { Year of } \\
\text { Construc- } \\
\text { tion }\end{array}$ & $\begin{array}{l}\text { Year of } \\
\text { Reconstruction/ } \\
\text { Renovation }\end{array}$ & \\
\hline Bixia gong & & & $\sqrt{ }$ & $\sqrt{ }$ & $\begin{array}{l}\text { Yuan } \\
\text { dynasty }\end{array}$ & $\begin{array}{l}1506 / 1533 / \\
1693 / 1741 / \\
1801 / 1992 / \\
1996\end{array}$ & Excellent \\
\hline Yuhuang miao & & & $\sqrt{ }$ & & Unknown & $1543 / 2001$ & Good \\
\hline Sanyuan gong & & & $\sqrt{ }$ & & 1720 & 1997 & Good \\
\hline Guanyin ge & $\sqrt{ }$ & & & & unknown & 1831 & Excellent \\
\hline Sandashi tang & & & $\sqrt{ }$ & & unknown & $\begin{array}{l}16431826 / \\
1912\end{array}$ & Good \\
\hline Guandi miao & & & $\sqrt{ }$ & & Unknown & Qing dynasty & $\begin{array}{l}\text { Poor } \\
\text { (renovation } \\
\text { under plan) }\end{array}$ \\
\hline $\begin{array}{l}\text { Zushi miao/ } \\
\text { Zhenwu miao }\end{array}$ & & & $\sqrt{ }$ & & Unknown & $\begin{array}{l}1847 / 1876 / \\
1995\end{array}$ & Good \\
\hline Baiyi tang & $\sqrt{ }$ & & & & Unknown & 1822/1916 & Good \\
\hline Cuijia tang & $\sqrt{ }$ & $\sqrt{ }$ & & & Unknown & 1809 & Good \\
\hline Tudi miao & & & $\sqrt{ }$ & $\sqrt{ }$ & Unknown & 1965 & Good \\
\hline Wenchang ge & & & $\sqrt{ }$ & & Unknown & Unknown & Dilapidated \\
\hline Fodian & $\sqrt{ }$ & & & & Unknown & Unknown & Dilapidated \\
\hline Lüzu an & & & $\sqrt{ }$ & & Unknown & 1965 & fair \\
\hline Tunainai miao & & & & $\sqrt{ }$ & $? 1944$ & $2000 / 2005$ & Excellent \\
\hline $\begin{array}{l}\text { Wudao miao in } \\
\text { the south of } \\
\text { village }\end{array}$ & & & $\sqrt{ }$ & & Unknown & Unknown & poor \\
\hline $\begin{array}{l}\text { Wudao miao in } \\
\text { the east of } \\
\text { village }\end{array}$ & & & $\sqrt{ }$ & & Unknown & Unknown & poor \\
\hline $\begin{array}{l}\text { Wudao miao in } \\
\text { the north of } \\
\text { village }\end{array}$ & & & $\sqrt{ }$ & & Unknown & 1828 & fair \\
\hline
\end{tabular}

Overwhelmingly dominant among them are Daoist temples and shrines, which vastly outnumber temples and shrines of any other religion and account for $65 \%$ of the total number of temples and shrines in Jiacun. It must be pointed out, however, that the above classification is far from black and white, as the boundary drawn between them is not always as clear-cut as is thought. This is because one can almost always find elements of one religion in temples or shrines of the other religion. A good example of this is the Cuijia tang, which is a sanctuary for ancestor worship as well as for Buddhist worship, as indicated by its alternative name Gu fotang or the Ancient Hall of the Buddha. As such, the distinction between them is more often than not a matter of degree rather than a matter of kind in a broad socioreligious context. 


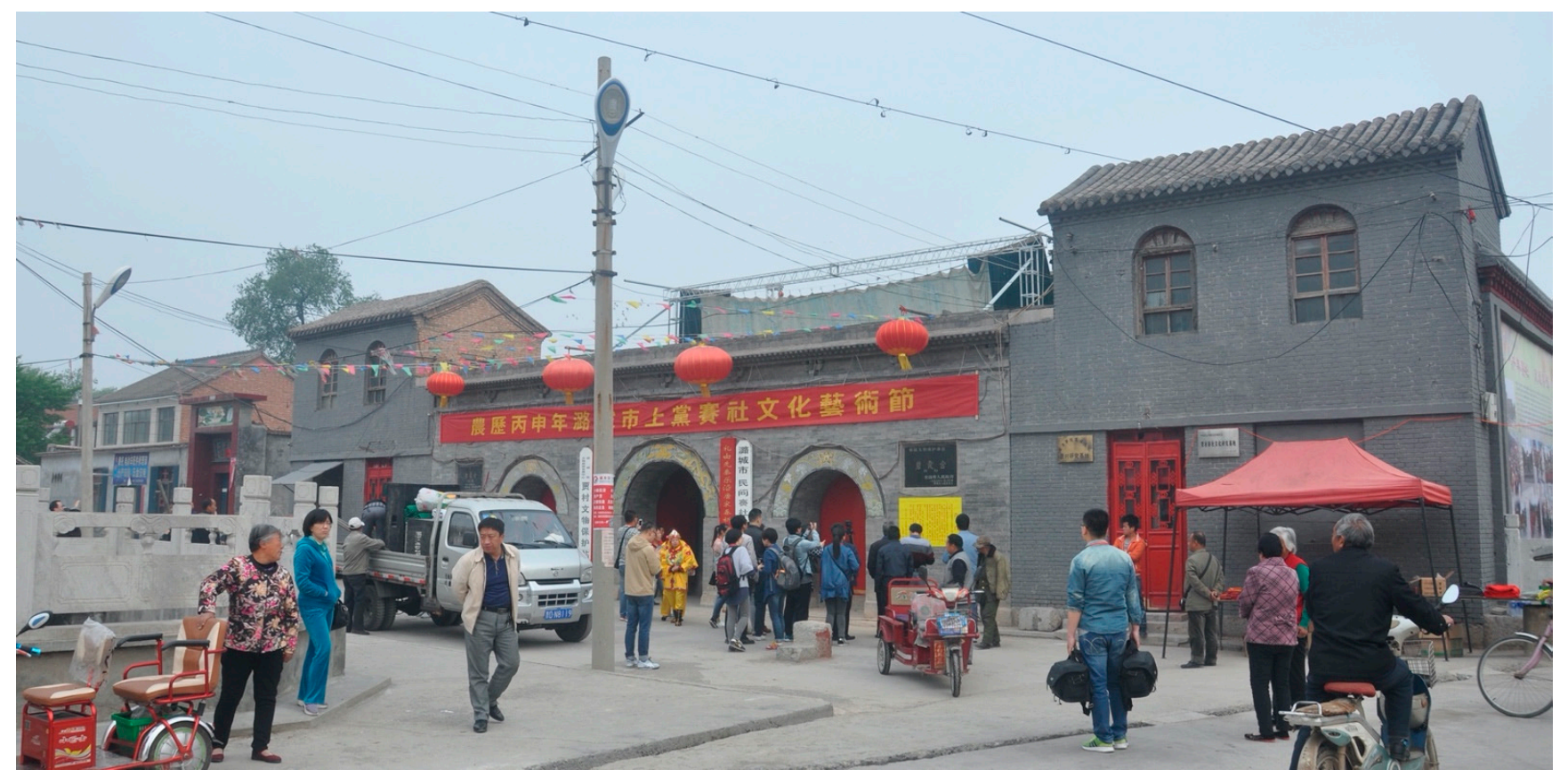

Figure 8. Bixia Temple Viewed from Outside.

This is particularly true of the borderline between Daoism and Chinese popular religion, for they share common origins or sources in many of their respective beliefs and practices. Since emerging as an organised form of religion from an integration of various folk beliefs, the Huang-Lao 老 thought and Lao-Zhuang 老莊 philosophy at the end of the second century AD, Daoism has never given up attempting to assimilate or synthesise local traditions and cults of local deities. A case in point is the Bixia gong dedicated to Bixia yuanjun or the Primordial Sovereign of the Morning Clouds, a goddess who, with her origin in the cult of Taishan 泰山 or Mount Tai, is widely worshipped in Daoism and folk religion in northern China as the Heavenly Immortal and Holy Mother (Tianxian shengmu 天仙聖母) charged with childbirth and childcare (Li 2018, p. 62)-a point to which we will return later in more detail. There are others in a similar vein. Take for example the Lüzu an, a shrine dedicated to Lü Dongbin 呂洞賓, the best-known of the Eight Immortals (baxian 八仙) in Chinese mythology and folk religion, who is also credited as a founder of Daoist Internal Alchemy (neidan f) and venerated as a patriarch of the Way of Completed Perfection (Quanzhen dao 全真道), one of the two major schools of Daoism along with the Way of the Celestial Masters (Tiansh dao 天師道). ${ }^{15}$ The same may be said of the Tudi miao, a small shrine dedicated to the Earth God (Tudi 土地). Also called the Lord of the Soil and the Orthodox Deity of Fortunes and Virtues (Fude zhengshen 福正神), among others, the Earth God was originally a local tutelary deity and was later incorporated into the Daoist pantheon of a bewildering myriad of gods, spirits and immortals (Chavannes 1910, pp. 437-525). This is also the case with Imperial Lord Wenchang (Wenchang dijun 文昌帝 君), the God of Culture and Literature in Daoism, whose cult originated from a local deity of Zitong 梓潼, a hilly county in northern Sichuan (Kleeman 1998), hence alternatively called Imperial Lord Zitong (Zitong dijun 梓潼帝君).

While a temple or shrine is generally named after the god or goddess to whom it is dedicated in China, it is not at all uncommon to find shrines or spirit tablets (paiwei 牌位) in its altars set up for the worship of other gods and goddesses. A case in point is the Zushi miao, a temple dedicated to the Perfected Warrior (Zhenwu 真武), also known as the Dark Warrior (Xuanwu 立武) in Daoist mythology. ${ }^{16}$ Interestingly, the Zhenwu miao is flanked by two small shrines: one on its western side dedicated to the God of Five Grains (Wugu 五穀) and the God of Wealth (Caishen 財神) and the other on its eastern side to Zhang Ban 張班 and Lu Ban 魯班 (See Figure 6). ${ }^{17}$ 


\section{Bixia Yuanjun and Bixia Gong in Jiacun}

The harmonious coexistence of temples and shrines for various religions and beliefs in Jiacun and that of halls or shrines built for the worship of various gods and goddesses in the Bixia Temple, as we shall see, are a common and distinctive feature of Chinese local religion. The Bixia Temple lies at the centre of Jiacun's north-south axis that runs through the Pavilion of Guanyin, the Temple of Emperor Guan, the Hall of the Cui Family and the Temple of the Patriarch. 'Sitting to the North, facing the South' (zuobei chaonan 坐北朝南), the temple is 69.7 metres long and 34.6 metres wide, covering an area of 2411.62 square metres (Figure 9). Across from a small square in front of its entrance gate is the Pool of the Morning Clouds (Bixia chi 碧霞池), a six hundred square metre pool enclosed with a carved stone balustrade. Also called the Divine Pool (Shenchi 神池), the pool was rebuilt in 1992 when the Bixia Temple underwent an extensive renovation (see Figure 8).

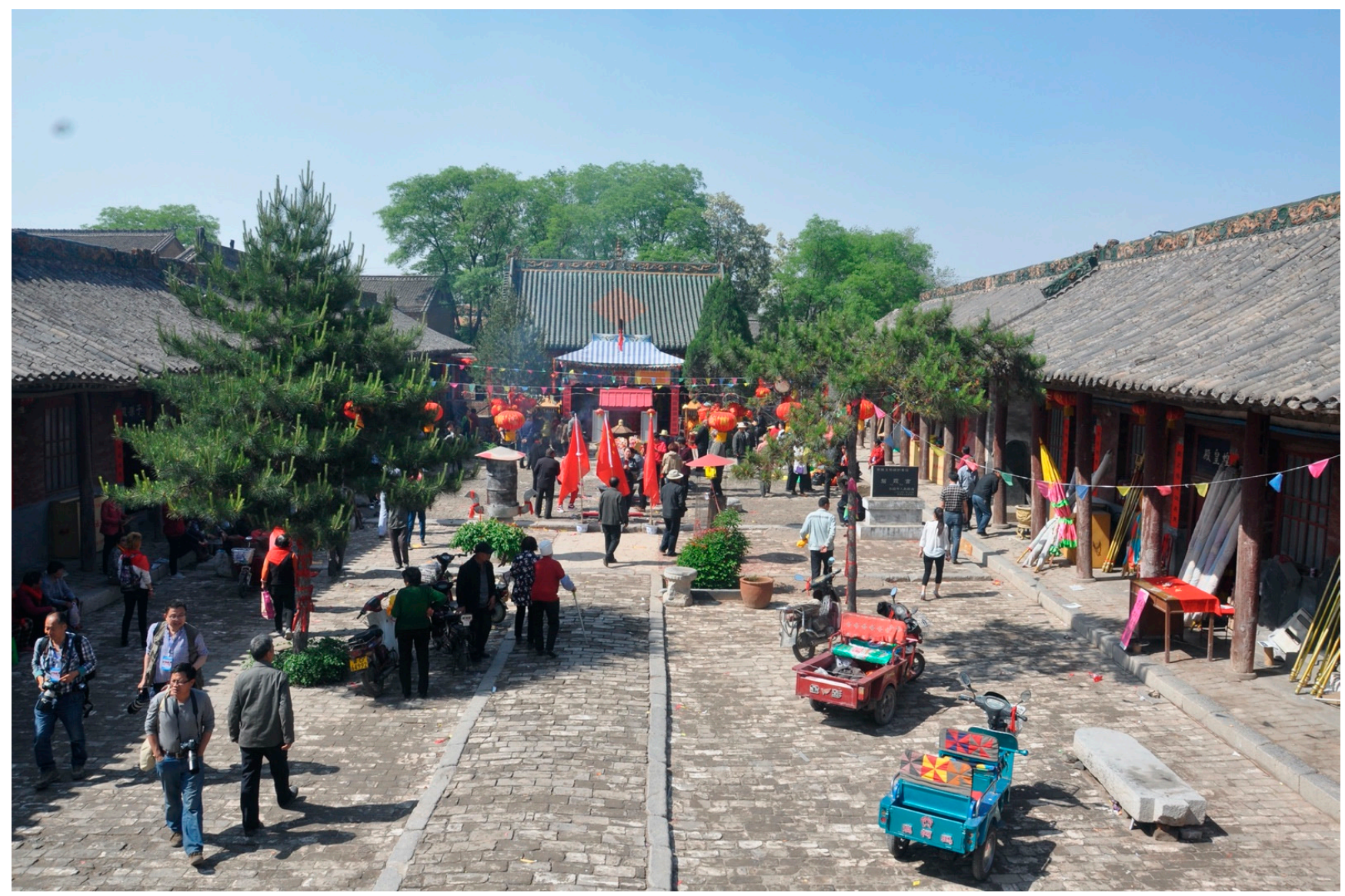

Figure 9. Bixia Temple Viewed from Stage over the Temple Gateway.

The temple is a three-row-and-two-courtyard (sanjin liangyuan 三進兩院) complex. Situated along the north-south axis of the temple are, in turn, the first row (qianjin 前進) that is the mountain gate (shanmen 山門) ${ }_{1}^{18}$ which is a two storey gatehouse with a roofless stage over the gateway (shanmen xitai 山門戲台) flanked by a corner tower (jiaolou 角樓) (Figure 9, see also Figure 8), the front yard (qianyuan 前院), the middle row (zhongiin 中 進), that is, the middle hall (zhongdian 中殿) or the main hall (zhudian 主殿), the rear yard (houyuan 後院) and the rear row (houjin 後進), that is, the rear hall (houdian 後殿), which serves as the sleeping hall (qindian 敄殿) for the goddess. The middle hall is the main building of the temple, at the centre of which stands an awe-inspiring statute of Bixia yuanjun, the principal deity of the temple, who receives sacrificial offerings and watches musical and theatrical performances presented in her honour during temple festivals; thus, the main hall is also called the hall for offering sacrifices or sacrificial hall (xiandian 獻殿) 
(Figure 10). The corner tower that flanks the stage is purpose-built to be multifunctional and is used by musicians and theatre actors as a lodge room, storage room, dressing room and entrance to and exit from the stage. The front section of the religious complex is designed to be a temple theatre with the stage over the gateway oriented towards the main hall across the front yard and conjoined on either side with seven side halls (peidian 配殿) extending westward all the way from the corner tower first to the middle hall and then to the rear hall, thus forming an enclosed space in the front section for staging and watching musical and theatrical performance.

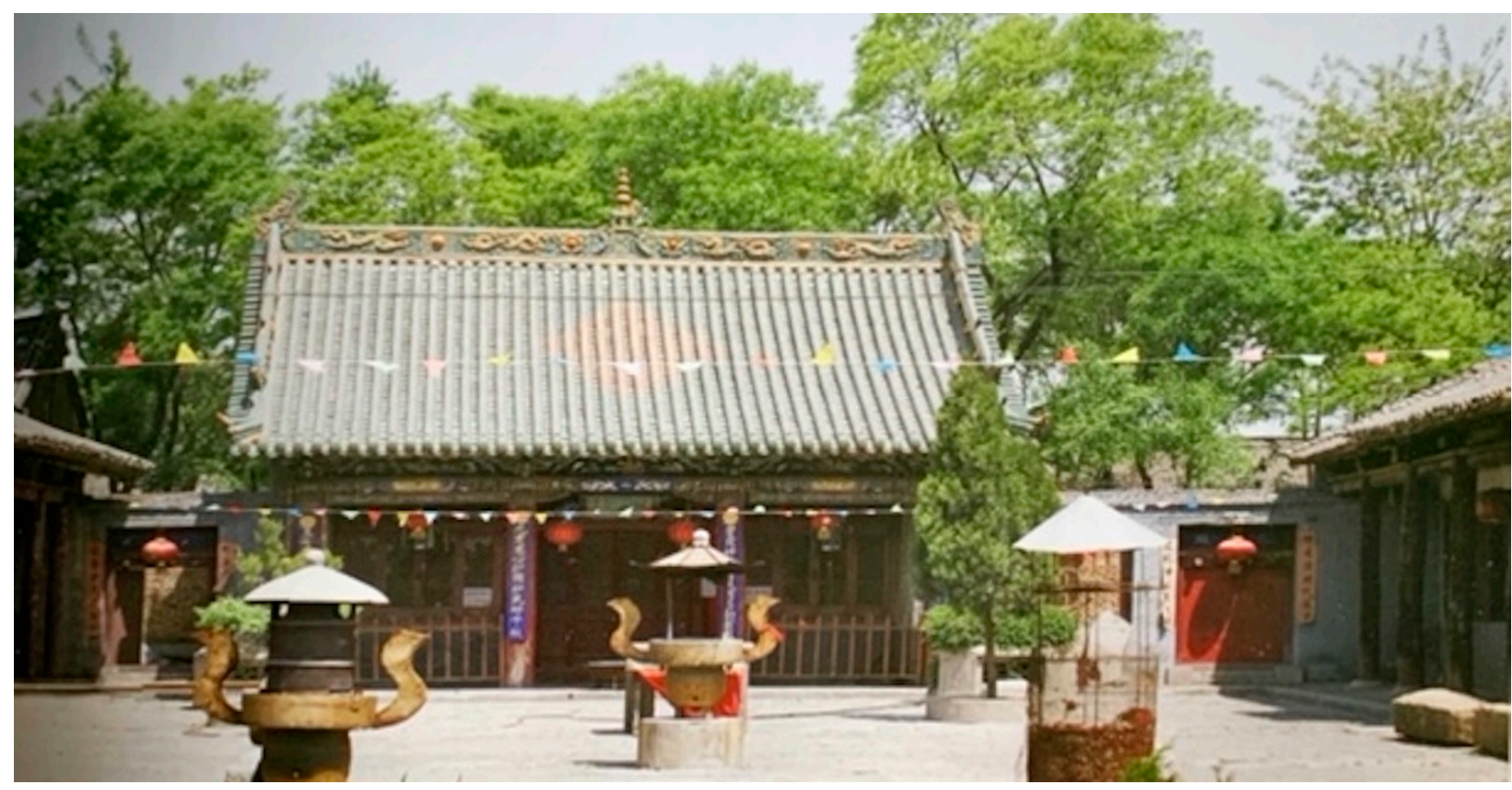

Figure 10. Main Hall/Sacrificial Hall.

The fourteen side halls are each dedicated to a subsidiary deity (fushen 輔神) or a grouping of minor deities. On the eastern side, from north to south, are the Hall of the Three Sovereigns (Sanhuang dian 三皇殿), ${ }^{19}$ the East-Side Hall of King Yama (Dong Yangwang dian 東閻王殿), the Hall of the Six Ding (Liuding dian 六丁殿), ${ }^{20}$ the Hall of Sanzong (Sanzong dian 三峻殿) (Figure 11), ${ }^{21}$ the Hall of (Lady Who Heals) Eyesight (Yanguang dian 眼光殿) (Figure 12), ${ }^{22}$ the Hall of the Locust Emperor (Huanghuang dian 蝗皇殿) (Figure 13) and the Hall of the Horse King (Mawang dian 馬王殿). ${ }^{23}$ On the western side, from north to south, are the Hall of the Eight Trigrams (Bagua dian 八卦殿), the West-Side Hall of King Yama (Xi Yanwang dian 西閻王殿), the Hall of the Six Jia (Liujia dian 六甲殿) (Figure 14), ${ }^{24}$ the Hall of Zhaoze (Zhaoze dian 昭澤殿), ${ }^{25}$ the Hall of Sons and Grandsons (Zisun dian 子孫殿) (Figure 15) ${ }^{26}$ the Hall of the Dragon King (Longwang dian 龍王殿) (Figure 16) and the Hall of Five Plague Spirits (Wuwen dian 五㨕殿) ${ }^{27}$ These gods and goddesses make up the pantheon of the Bixai Temple, headed by the Primordial Sovereign of the Morning Clouds or Bixia yuanjun.

The cult of Bixia yuanjun is closely associated with the cult of Mount Tai (Taishan 泰 山), which has its roots traceable to the ancient official state ceremonies of fengshan 封樿 performed on Mount Tai to offer sacrifices to Heaven (feng 封), and on Mount Liangfu 梁 父, a small hill nearby, to Earth (shan 禪). ${ }^{28}$ Also known as Daizong 岱宗, Daishan 岱山, Daiyue 岱獄 and Dongyue 東获 or the Eastern Peak, Mount Tai is a sacred mountain in present-day Shandong province, ranking as the first of the five sacred mountains (wuyue 
五啍) in China..$^{29}$ As the most revered of the five sacred mountains, Mount Tai enjoyed a privileged relationship with the royal court in imperial China.

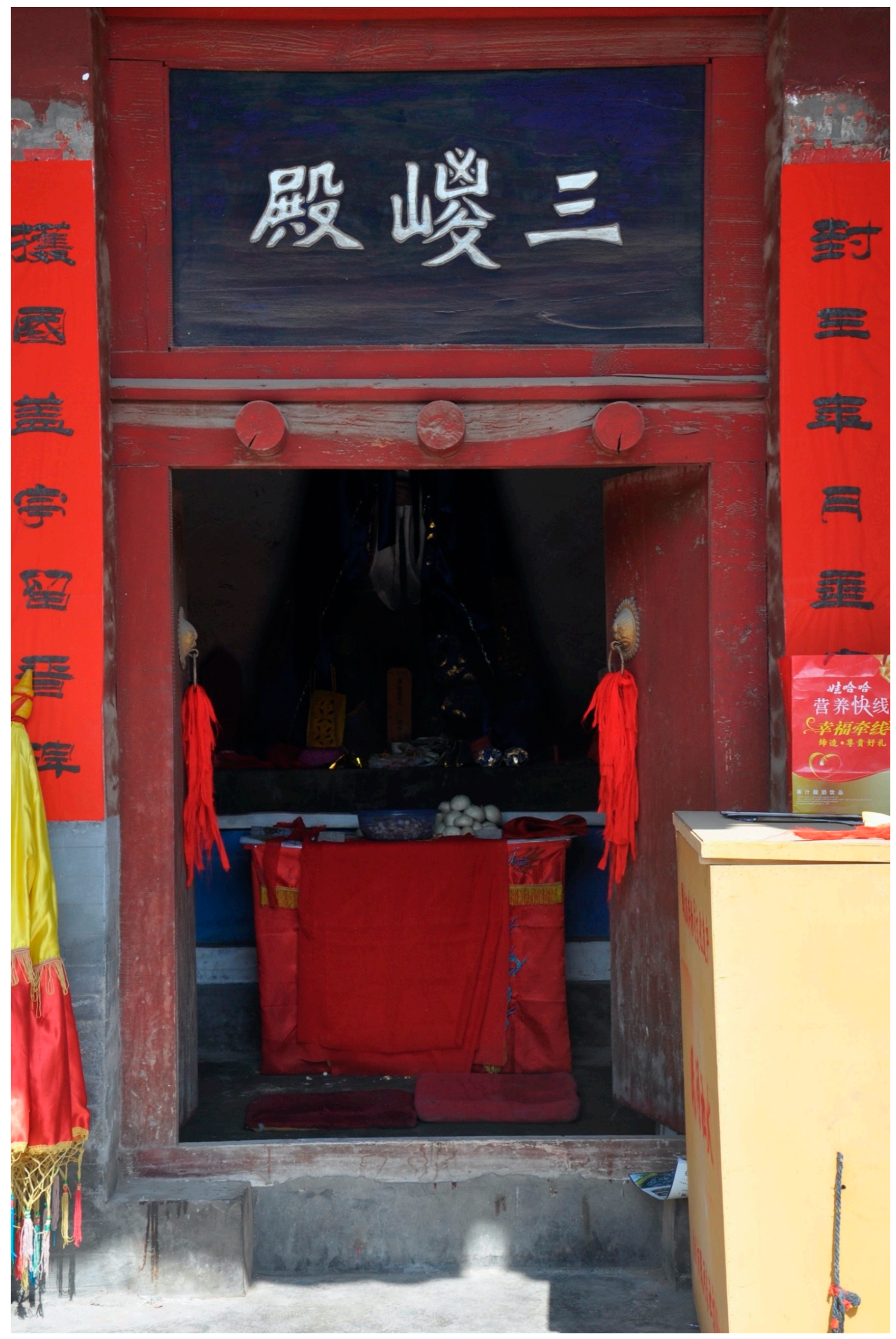

Figure 11. Hall of Sanzong. 


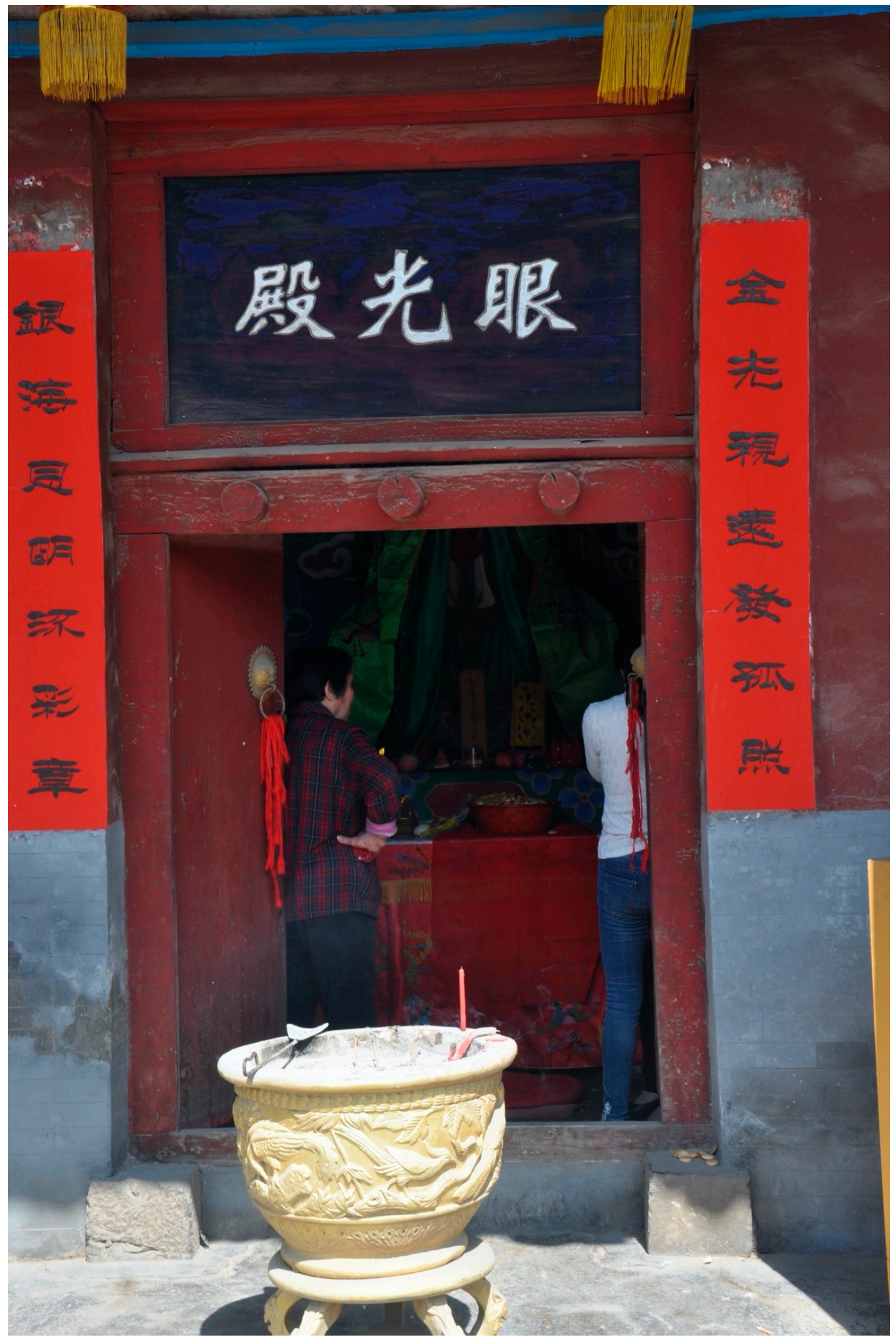

Figure 12. Hall of Eyesight. 


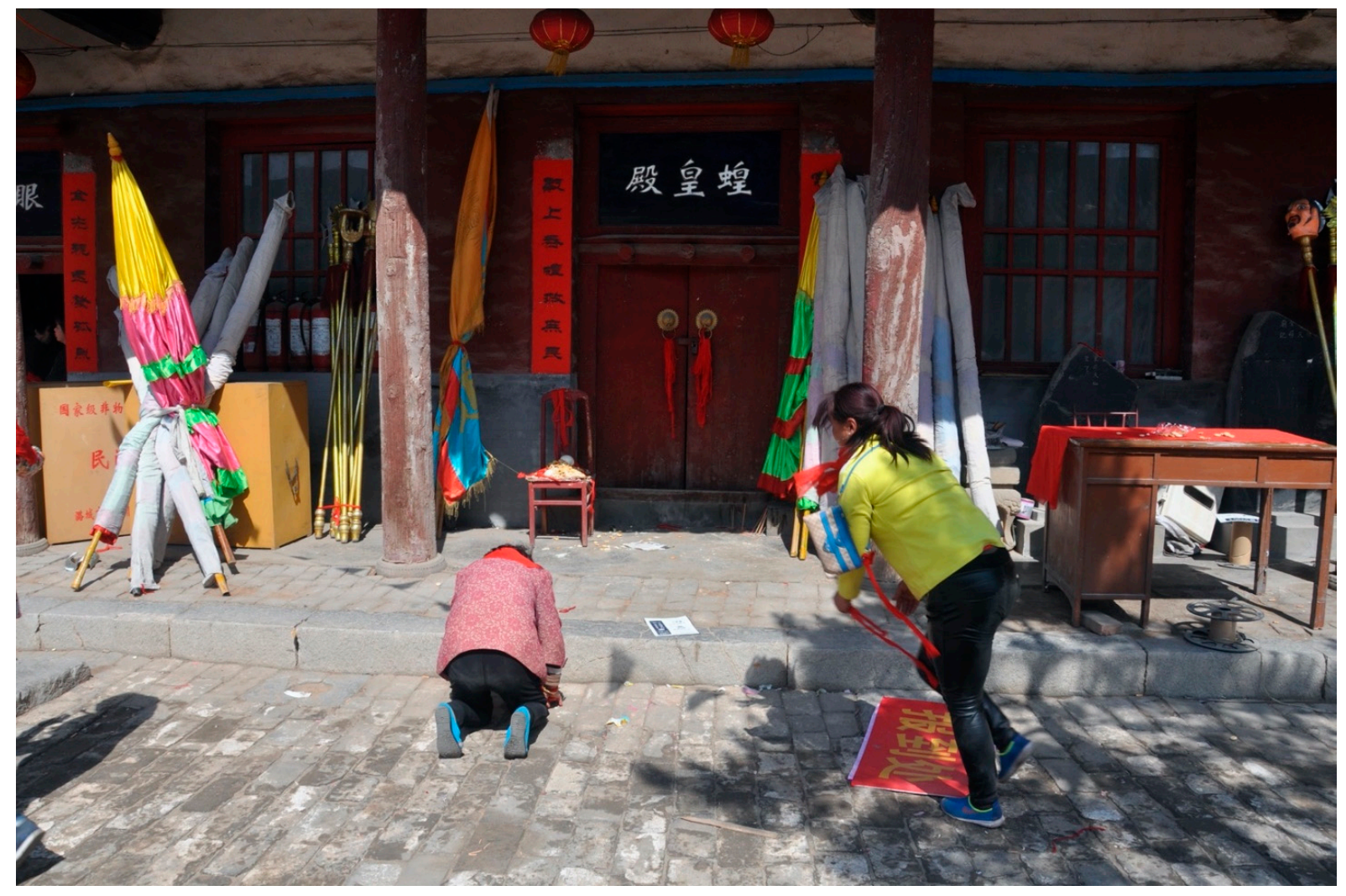

Figure 13. Hall of Locust Emperor.

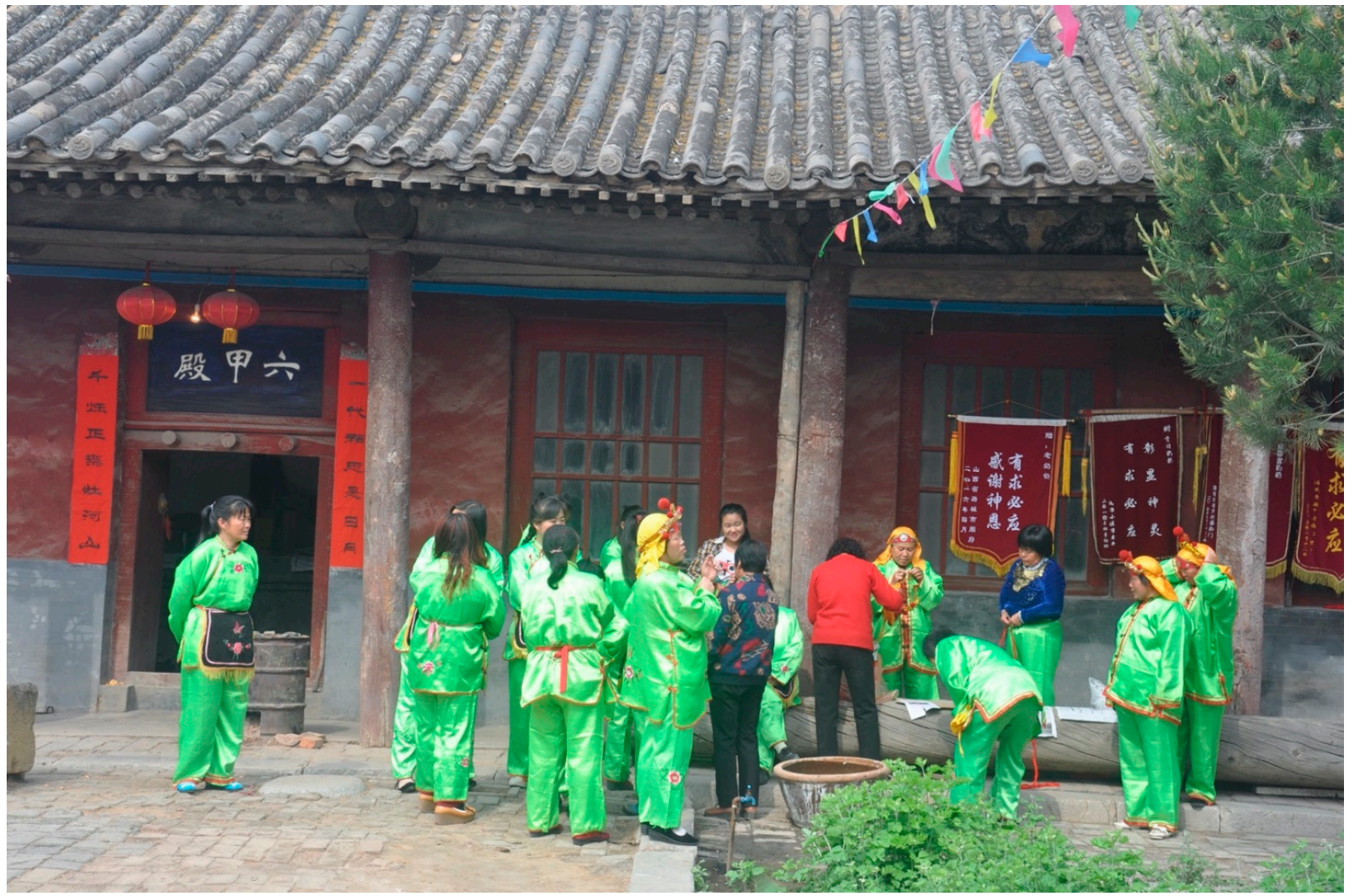

Figure 14. Hall of Liujia. 


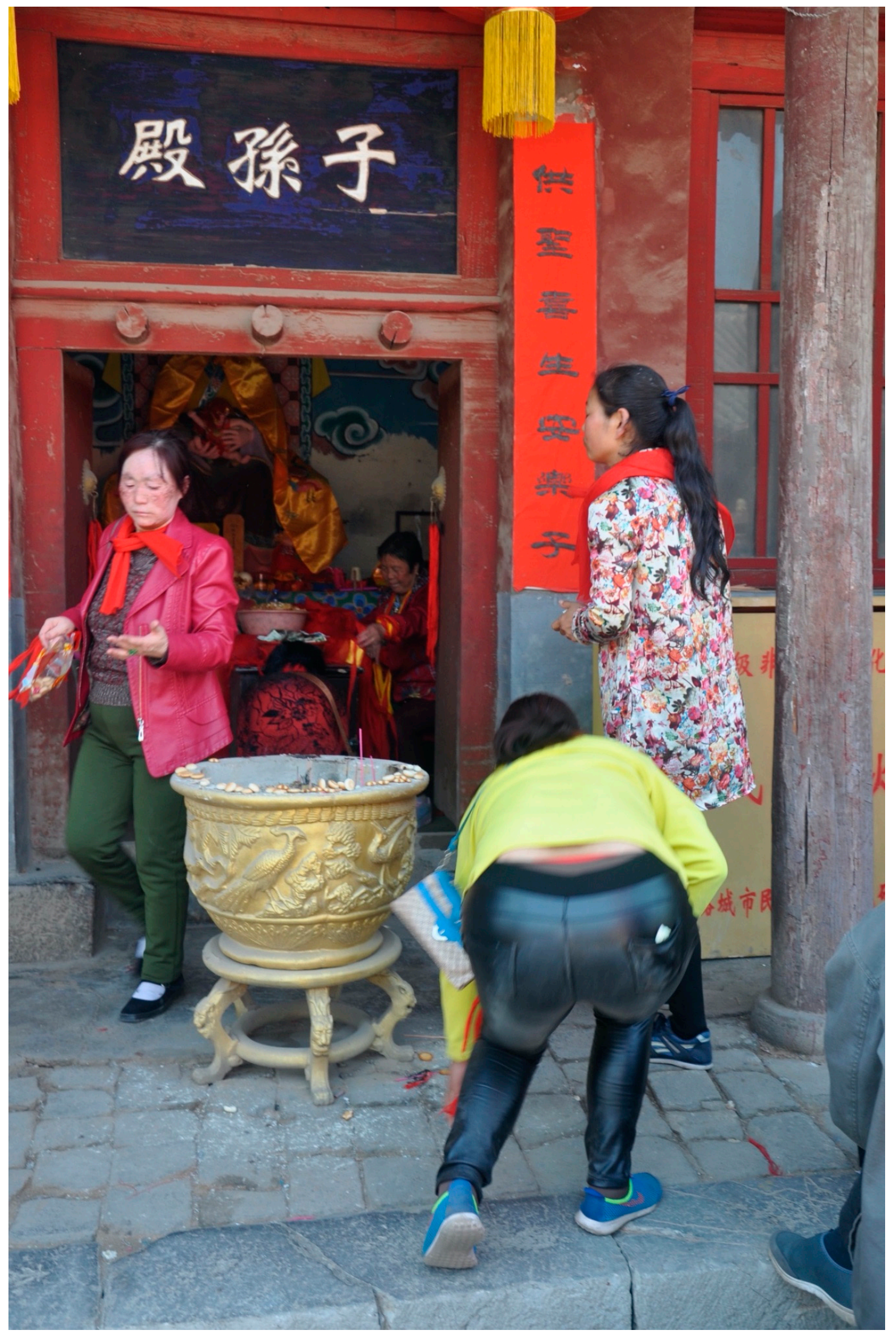

Figure 15. Hall of Sons and Grandsons. 


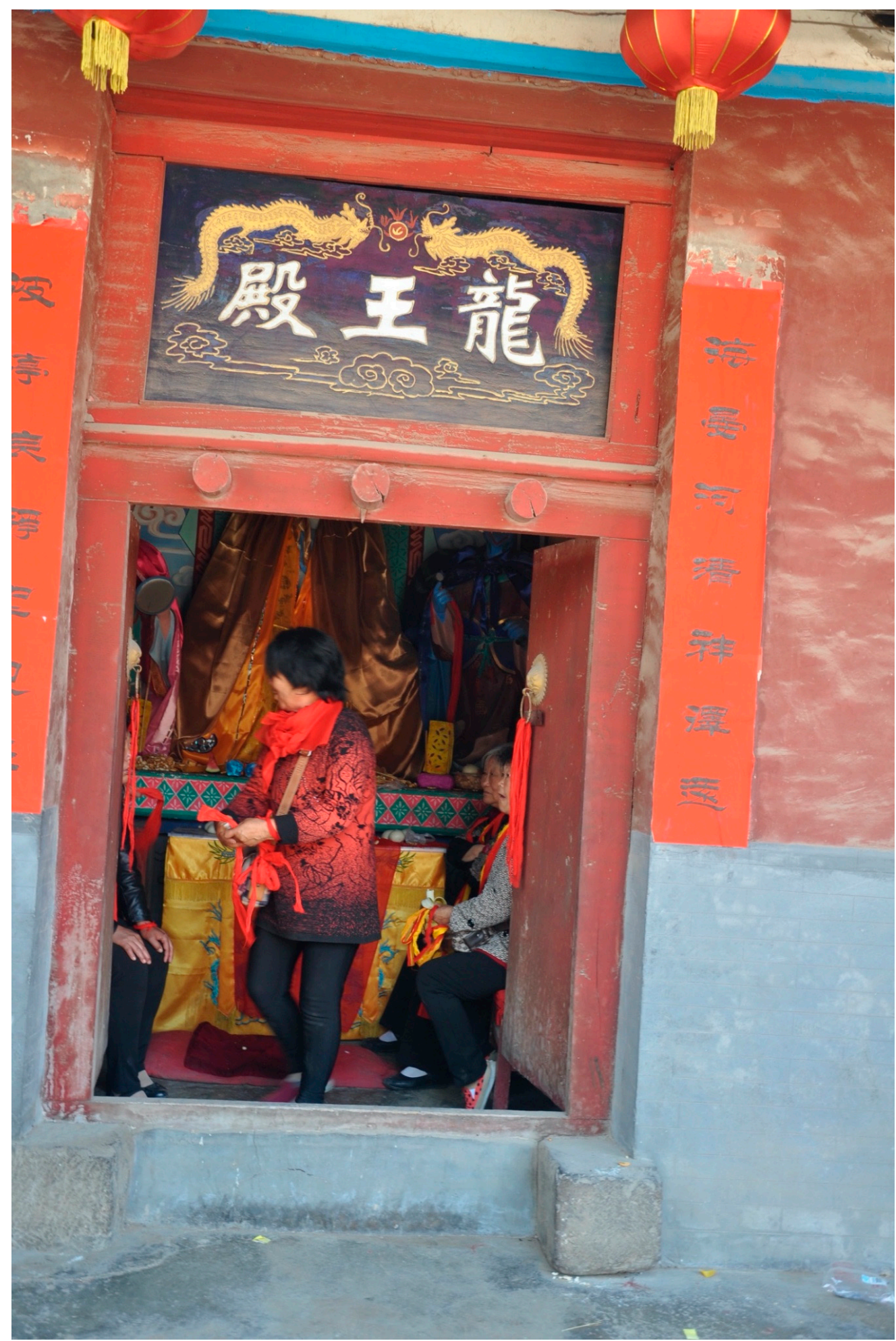

Figure 16. Hall of Dragon King.

Mount Tai was worshipped not only as the sacred mountain for the imperial ceremonies of fengshan but also as the final destination or disposition for the souls of the dead in Chinese folk religion. In pre-Buddhist China, it was widely believed that the Lord of Mount Tai (Taishan fujun 泰山府君) ruled from Mount Liangfu over the souls of the dead in the Dark Realms (yinjian 陰間) (Gaiyu congkao 35: 3a-4b; see also Okamoto 1943, cited in Yü 1987, p. 389), as does King Yama over ghosts in Hell in Chinese Buddhism. The 
mountain was deified and its cult was incorporated into the officially mandated 'Register of Sacrifices' (sidian 艳典) during the Tang dynasty. In the thirteenth year (724) of Kaiyuan 開 元, Emperor Xuanzong 立宗 (712-756) of Tang granted Mount Tai the noble title of the King Who Equals to Heaven (Tianqi wang 天夜王) following an imperial ceremony of fengshan on Mount Tai (Jiu Tangshu 23.901, 24.934). The following dynasties witnessed higher and higher royal titles conferred on the Eastern Peak (Gaiyu congkao 35.2b-3a). Among them were the Benevolent and Holy King Who Equals to Heaven (Rensheng tianqi wang 仁聖天 齊王) (Songshi 102.2486), the Benevolent and Holy Emperor Who Equals to Heaven (Tianqi rensheng di 天齊仁聖帝 (ibid.) and the Benevolent, Holy and Greatly Life-Giving Emperor of the Eastern Peak Who Equals to Heaven (Tianqi dasheng rensheng di天齊大生仁聖帝) (Yuanshi 72.1900). In late imperial China, the god was popularly referred to as the Great Emperor of the Eastern Peak (Dongyue dadi 東获大帝). With his rank promoted from prefect ( $f u$ 府) to king (wang 王) to emperor ( $d i$ 帝), the mountain god was firmly established as the supreme deity of the Eastern Peak. His ascension to the status of $d i$ comes as no surprise considering the great popularity the mountain god had enjoyed for centuries as one of the Ten Kings of Hell alongside King Yama in Buddhism (Foshuo Dizang pusa faxin yinyuan shiwang jing X01n0020.1: 0405a24, 1.0407a13) and as the supreme ruler overseeing the life and death of mortal beings in Daoism and folk religion (Hou Hanshu 82.2731). ${ }^{30}$ Beginning in the Song dynasty, his cult spread across the country, and the god became so popular that one could hardly find a county or district without a Dongyue miao 東获廟 or Temple of the Eastern Peak.

His popularity reached its zenith in the mid-to-late sixteenth century when there occurred a sudden shift of focus in the cult of Mount Tai to Bixia yuanjun, whose image or statue as the daughter of Dongyue dadi seems to have found its way overnight into a great many of Dongyue miao in northern China (Goossaert 2011, p. 379). This is amazing given that the name Bixia yuanjun does not appear in any text earlier than the fifteenth century (Gyss 2011, p. 235). Beginning in the mid-eighteenth century at the latest, Bixia yuanjun replaced Dongyue dadi as the most popular deity in the pantheon of Mount Tai. In 'Epigraph for the Primordial Sovereign' ('Yuanjun ji' 元君記), Han Xizuo 韓錫胙, a High-Qing scholar-official, writes: 'The Eastern Peak ranks as the first among gods and spirits under Heaven from past to present, so does the Primordial Sovereign among the gods and spirits of Mount Tai.' The first half of the statement is an exaggeration; the second half is not. In Qing times (1644-1911), for example, Shandong boasts more than three hundred temples and shrines devoted to the goddess, and this is also largely true of her cult in Qing Beijing, Hebei and Shanxi (Ye 2009; Tian 2004).

Just because the name Bixia yuanjun is not found in any text earlier than the fifteenth century, it does not mean that the goddess appeared out of thin air in sixteenth-century China. Although it remains a subject for debate as to how the goddess emerged from the cult of Mount Tai and how she came to replace Dongyue dadi as the most popularly worshipped deity in the pantheon of Mount Tai, there is evidence that her cult began at the turn of the eleventh century at the latest, when the goddess was worshipped as the Jade Maiden of Mount Tai (Taishan yunü 泰山玉女), a title granted to her by Emperor Zhenzong 真宗 (r. 997-1022) of the Song dynasty (Wenxian tongkao 90.22b-23a; Rizhi lu $25.9 \mathrm{~b}-10 \mathrm{a})$. Among various other titles the goddess was known by are the Holy Mother of Mount Tai (Taishan shengmu 泰山聖母), the Old Lady of Mount Tai (Taishan laonainai 泰山老奶奶), the Lady of Mount Tai (Taishan niangniang 泰山娘娘), Lady Jade Maiden (Yunü niangniang 玉女娘娘), Jade Maiden the Great Immortal (Yunü daxian 玉女大仙), the Jade Immortal and Holy Mother (Yuxian shengmu 玉仙聖母), the Heavenly Immortal, Jade Maiden and Primordial Sovereign of the Morning Clouds (Tianxian yunü Bixia yuanjun 天 仙玉女碧霞元君) and the Heavenly Immortal, Holy Mother and Primordial Sovereign of the Morning Clouds (Tianxian shengmu Bixia yuanju 天仙聖母碧霞元君) (Ye 2007).

There are more titles that can be added to the list, which accounts for the great popularity of Bixia yuanjun in late imperial China. Noteworthy is that the goddess is also known in the Shangdang area as the Three Immortals, Child-Giving Lady and the 
Primordial Sovereign of Mercy and Wisdom (Sanxian songzi niangniang ciyi yuhui yuanju 三仙送子娘娘慈懿育慧元君) ${ }^{31}$ and the Fecund Holy Mother of the Ninth Heaven, Guardian of the Delivery Room and Primordial Sovereign (Duo'er duonü jiutian weifang shengmu yuanjun 多兒多女九天衛房聖母元君), which are recorded in the 'Stele Inscription of Rebuilding the Palace of the Primordial Sovereign of the Moring Clouds' ('Chongxiu Bixia gong beiji' 重修碧霞宮碑記) (Figure 17). Located in Chengiiachuan 成家川 of Lucheng, about ten kilometres east of Jiacun, this Bixia temple is locally called 'Temple of the Lady of the Ninth Heaven' (Jiutian niangniang miao 九天娘娘廟) or simply as 'Temple of the Lady' (Niangniang miao 娘娘廟).

In the celestial bureaucracy of Daoism, there is an agency called the Office in the Ninth Heaven for Childbirth (Jiutian jiansheng si 九天監生司) in charge of human baby delivery and nursery. The Holy Mother of the Ninth Heaven and Guardian of the Delivery Room (Jiutian weifang shengmu 九天衛房聖母) is one of the eighteen major deities staffed in the office, as described in the thirteenth-century liturgical text titled Golden Book for Universal Salvation According to the Sect Leader of the Numinous Treasure Tradition (Lingbao lingjiao jidu jinshu DZ 466: 57.15a, 239.1a-4a) ${ }^{32}$ and also in the two anonymous Daoist scriptures: the Oracular Slip of the Great Compassionate, Life-Loving Holy Mother of the Ninth Heaven, Guardian of the Delivery Room and Primordial Sovereign (Daci haosheng jiutian weifang shengmu yuanjun lingying baoqian DZ 1300: 1a-2b) and the Precious Scripture of the Celestial Worthy and Jade Pivot of Universal Transformation on the Echo of Thunder from the Ninth Heaven to the Primordial Origin (Jiutian yingyuan leisheng puhua tianzun yushu baojing DZ 16: 6a-7b). ${ }^{33}$

Clearly, Bixia yuanjun is confused or merged with Jiutian shengmu, the goddess of childbirth and childcare, into the Office in the Ninth Heaven for Childbirth or vice versa with Jiutian shengmu, merged into the pantheon of Mount Tai and identified with Bixia yuanjun, the goddess of Mount Tai, as one and the same deity. The confusion or identification of Bixia yuanjun with Jiutian niangniang as we have seen in the Bixia Temple of Chengjiachuan also occurs with the Bixia Temple in Gaocun 高村, a village in Changzhi county about twenty kilometres southwest of Jiacun. The temple plaque (miao' $e$ 廟額) bears three Chinese characters—shen 聖 (holy), mu 母 (mother) and miao 廟 (temple), and the three bronze censers in the temple are all marked with jiutian shengmu miao 九天聖母廟, meaning 'Temple of the Holy Mother of the Ninth Heaven', whereas its main hall is named the 'Shrine of the Primordial Sovereign of the Morning Clouds' (Bixia ci 碧霞柌) with a statue of the goddess seated at the centre of the hall. Inscribed on a temple stele erected in the eighth year (1580) of Wanli 萬, a reign period of the Ming dynasty, is 'A Record of Rebuilding the Traveling Palace of the Primordial Sovereign' ('Chongxiu Bixia yuanju xinggong ji' 重修碧霞元君行宫记). In the inscribed text, the goddess is referred to as 'the Holy Mother of the Ninth Heaven and the Primordial Sovereign of the Morning Clouds of Mount Tai the Eastern Peak' (Dongyue Taishan Jiutian shengmu Bixia yuanjun 東猚泰山 九天聖母碧霞元君) (Fanzhou 2021). Here and again, we see the cult of Mount Tai being integrated with that of the Ninth Heaven and the Primordial Sovereign of the Morning Clouds being entrusted with the divine responsibility for childbirth and childcare that used to be almost exclusively undertaken by the Holy Mother of the Ninth Heaven in Daoist mythology. Significantly, the Travelling Palace of the Primordial Sovereign of the Morning Clouds in Gaocun was rebuilt (and probably renamed at the same time) during the reign of the Wanli emperor (1573-1620) — a period that witnessed the mountain goddess rising quickly to fame as one of China's three principal female deities alongside Guanyin and Tianhou 天后 (Queen of Heaven, also known as Mazu 馬祖) thanks to royal patronage (Pomeranz 2007, p. 29; Li 2018, pp. 60-61). The dual naming of the temple as we have seen above also appears in the Bixia Temple in Jiacun, as indicated by the temple plaque above the mountain gate that leads to the entrance hall of the temple, which reads 'Temple of the Holy Mother of the Ninth Heaven (Jiutian shengmu miao 九天聖母)廟) (Figure 18). Interestingly, however, its main hall is named Bixia gong or the Palace of the Morning Clouds, and the temple is locally called Nainai miao 奶奶廟 or Grandma Temple as well. 
Clearly, Bixia yuanjuan and Jiutian shengmu are worshipped as one and the same goddess in Jiacun, as elsewhere in Shangdang (Li 2016).

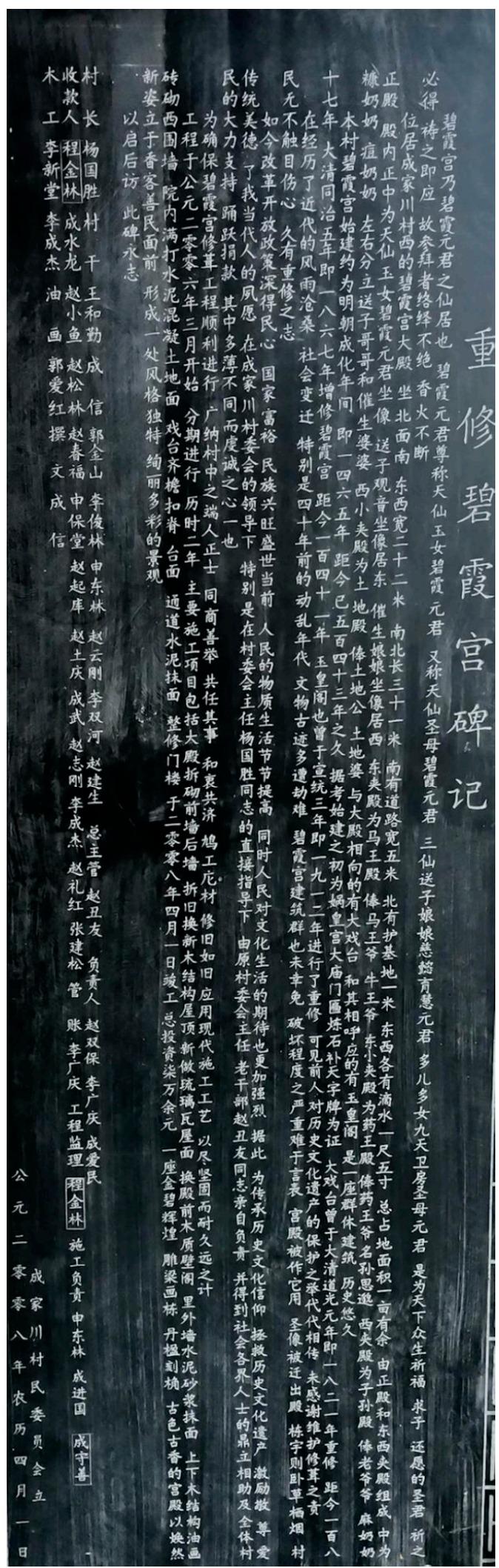

Figure 17. Chengjiachuan Bixia Temple Stone Stele. 


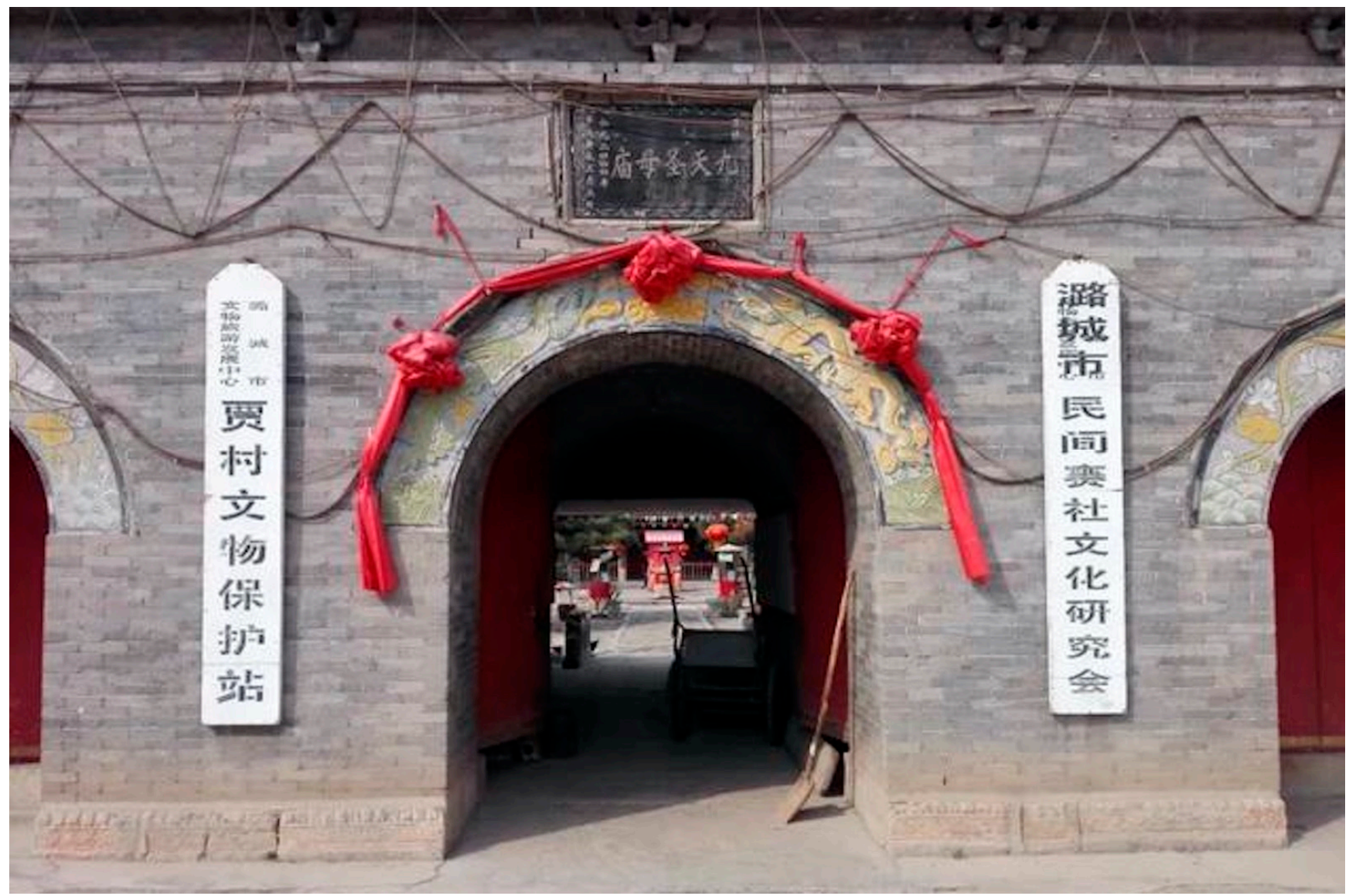

Figure 18. Temple Plaque above the Gate Leading to the Entrance Hall.

With a verifiable record of history going back to the fifteenth century or even earlier, the Bixia Temple is the largest and oldest of all the temples and shrines in Jiacun village and is also the oldest of Bixia temples and shrines still extant in the Shangdang area. Available to us are eight stone stelae, on which are inscribed records of renovating and reconstructing the temple over the past few centuries (Du 2011b, pp. 2-7). The oldest of them was erected in the first year (1506) of Zhengde 正德 during the Ming dynasty with a short text inscribed on it about the background to the reconstruction of the temple in that year (Du 2011b, p. 2). The text traces the history of the cult of the Holy Mother of the Ninth Heaven to the Tianyou 天祐 period (904-924) of the Tang dynasty but stops short of giving any detail or evidence; when it comes to the rationale behind the reconstruction of the temple, the text reveals that no one knows exactly when the temple was first built due to a lack of records. Apart from the eight stelae, there is one that fails to survive in its entirety except for a fragmentary piece preserved in the temple. Still visible on it is a vertical line of Chinese characters, which read: 'Rebuilt on the twenty-fourth day of the second month of the eighth year of Zhengtong' (Du 2016; Wang 2007, pp. 18-19). Zhengtong 正統 was a reign period (1435-1449) of Emperor Yingzong 英宗 of the Ming dynasty. The stone stele, albeit extant only in fragmentary form, strongly suggests that the temple was first built much earlier than 1443-that is, the eighth year of Zhengtong. The history of the temple may even be traced to the Yuan dynasty (1271-1368) (Li 2016), as evidenced by the main structure of the main hall of the temple which demonstrates a style characteristic of the architecture of the Yuan dynasty (1271-1368) (Wang 2007, p. 21; Guo 2020, p. 52). 


\section{Bixia Temple Festival}

While the beginning history of the Bixia Temple Festival in Jiacun remains unclear, there is evidence that by the late sixteenth century at the latest, a highly sophisticated protocol of ritual and theatrical performances had been developed for village festivals, as shown in the Lijie chuanbu, a liturgic handbook copied in 1574 by Cao Guozai 曹國宰, a ritual specialist of Jiacun, from a master copy datable to the Jiajing 嘉靖 era (1522-1566) of the Ming dynasty (Han et al. 1987a, p. 56n3). Discovered in 1985 in Nanshe, a member village along with Jiacun of the above-mentioned Eight Big Village Worship Associations, the text was originally owned by the Niu 牛 family in Jiacun, and in 1956, it fell into the hands of Cao Zhan'ao 曹占 and his brother Cao Guobiao 曹占標, diviners and geomancers of Nanshe village (Du 2011b, p. 235). Dated on its cover page 'Wanli second year, first month, thirteenth day' (4 February 1574), the text refers to itself on its first page as Zhou yuexing $t u$ (Figure 19). This manuscript served as a practical guide for local ritual organisers and performers for more than three hundred and fifty years until the War of Resistance Against Japan (1937-1945) (Han et al. 1987a, pp. 53-54) and has continued to do so since it was recovered in 1986 (Du 2016; Song 2016a).

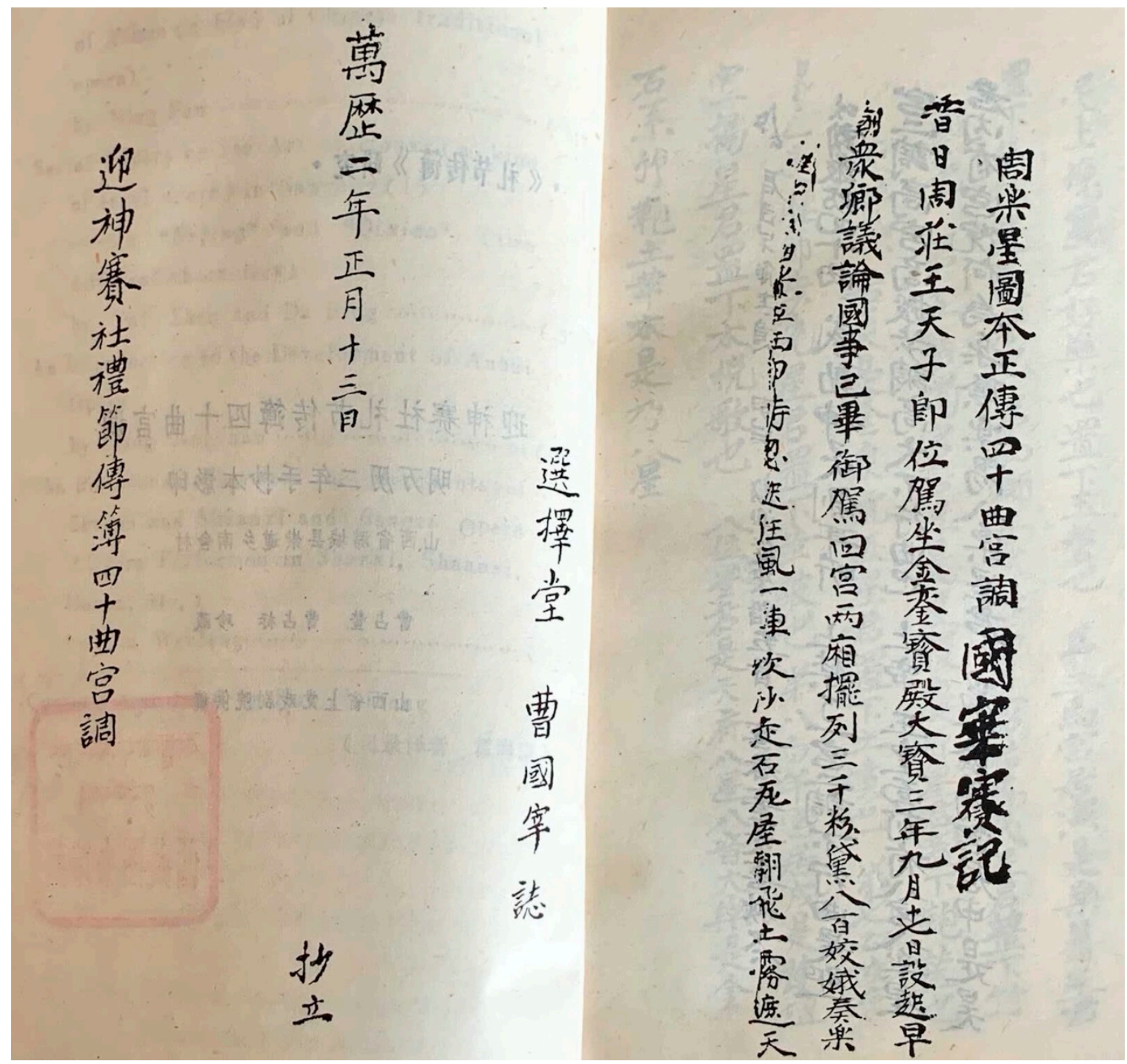

Figure 19. Cover and First Pages of Lijie chuanbu/Zhou yuexing tu. Source: Zhonghua xiqu 3 (1987), pp. 2-3. 
Temple festivals are an integral part of village life in rural North China (Overmyer 2009). Jiacun is no exception. There are various ceremonial and festival events. Some of them are family-based rituals and ceremonies, such as funerals, weddings and ancestral rites, and some of them are community-based temple festivals, such as the Double-Second Burning Incense Festival (Eryue'er xianghuo hui二月二香火會) and Double-Fourth Temple Festival in Jiacun, both held in honour of Bixia yuanjun with the Bixia Temple as the major venue for ritual and theatrical performance during the festival. As its name suggests, the Double-Second Burning Incense Festival falls on the second day of the second lunar month, but it is actually a three-day event starting on the thirtieth day of the first month and running through until the second day of the second month when it peaks (Du 2011a, pp. 68-78). The Double-Second Festival is celebrated in its own right and the same time as a prelude to the Double-Fourth Temple Festival, the most important sai in Jiacun, which is held to celebrate the birthday of Bixia yuanjun.

In history, the annual Double-Fourth Festival was normally celebrated as a three-day xiaosai 小賽 or small sai, and every forty years there would be a large-scale celebration called dasai 大賽 or big sai held over the course of six consecutive days in the fourth lunar month. The last time the big sai took place was 1917 (Du 2016). However, the centuries-long tradition failed to carry over to the next fortieth year. In early 1957 when villagers planned to hold a big sai, according to Du Tonghai (Du 2016), a highly revered local Community Head, an order came from above to call it off. The year 1996 witnessed the restoration of the Double-Second Festival for the first time since it was last held in 1945, and the following year witnessed the 'large-scale re-enactment of ancient temple festivals', which ran over six days from the first to the sixth day of the fourth month on the Chinese lunar calendar (Wang 2007, pp. 49-55). The Bixia temple festival has since been held annually but usually on a smaller scale than before because many people leave for work in cities and only return home for the Spring Festival once a year (Du 2016). Although staged on a smaller scale than before, Jiacun temple festivals remain fundamentally unchanged in form and function from the past, with the procedure and programme stipulated in the received liturgical texts faithfully observed whenever possible, as I was told by Du Tonghai (Du 2016). Noticing a look of surprise on my face, he showed me a stack of papers containing detailed instructions, invocations and prayers in verse and prose for the Double-Fourth Festival and kindly let me take a photograph of each and every page he had copied from the liturgical texts, with notes, signs and symbols densely written in the margins.

I do not have the slightest doubt that there is any substantial change made to the general structure and procedure of the temple festival, but to believe that the temple festival in its newly reconstructed form resembles what was presented a century ago in every respect would be nothing but wishful thinking, as cautioned by Johnson (2009, p. 39) in his observation of the New Year festival in the village of Renzhuang in southeastern Shanxi, which was restored based on a liturgy discovered in 1987. In any case, however, the Double-Fourth Temple Festival has once again become an important part of village life in Jiacun, albeit in a reconstructed form, through which traditional ritual and theatrical performances that would otherwise have been lost are revived and reintegrated into the mainstream of local religion.

The ritual procedure and programme of Jiacun temple festivals are organised around the Twenty-Eight Mansions (Ershiba xingxiu 二十八星宿) in the Chinese constellation pantheon, beginning with the mansion of 'Horn Represented by the Wood Dragon' (Jiao mujiao 角木蛟) and ending with that of 'Chariot Represented by the Water Earthworm' (Zhen shuiyin 軫水蚓), as described in the 1574 liturgical text, where each mansion is given a name, followed by a mythical creature or guardian deity, according to the Chinese astrology. ${ }^{34}$ Under the name of each mansion is a list of ritual, musical and theatrical performances including the ritual of offering cups (gongzhan 供荿) and performing variety shows (Du 2011b, pp. 246-83). Recorded in the ritual text are a total of 245 titles of melodies, songs, dances, dance dramas and dramas, 198 of which are dance dramas and dramas with 
their origins datable to the Song, Jin, Yuan or Ming dynasty (Han et al. 1987b, pp. 131-36; Huang 1987, pp. 137-43; Zhang 1987, pp. 153-67).

The theatrical performance may be classified into three broad categories in terms of liturgical procedures and functions: (1) full-length performances presented on temple theatre stage after offering the seventh and final cup to deities, (2) short interlude performances presented in front of the hall for offering sacrifices, respectively, between offering the fourth and fifth cups and between offering the fifth and sixth cups, and (3) music and dance dramas in processional performances. Dramatic pieces staged after the completion of the ritual of offering cups ${ }^{35}$ are categorised, respectively, as yuanben 院本 (farce, lit. 'court text'), ${ }^{36} z a j u$ 雜劇 (sketch comedy) and zheng duixi 正隊戲 (main group skit) in the liturgical manual. The zheng duixi is so named to distinguish it from the gongzhan duixi 供盄隊戲 (group skit for offering cups) and the ya duixi 颔隊戲 (muted group skit) (Huang 1998). The gongzhan duixi is meant for the interlude performance between offering cups, and the ya duixi-an ancient form of unspoken and unsung music and dance drama datable to the Tang and Song dynasties (Dou 1987) - is presented in processions by the Entertainers as warm-ups or rehearsals for the temple festival according to local ritualists (Li 1993b, 1993c).$^{37}$ I had the good fortune to find all the three forms of theatrical performance presented during my fieldwork in Jiacun on the Double-Fourth Temple Festival in May 2016. It was a year for small sai though, and accordingly, the procedure and programme reserved for the six-day big sai was simplified and adjusted to accommodate the form of a small sai.

The temple festival involves a great number of people. Most prominent among them are the Chief Community Head (weishou 首), the Chief Master of Ceremonials (zhuli 主禮), the Leader of Entertainers (qianhang 前行), Masters of Ceremonials (lisheng 禮生 or sili 司 禮) and Incense Elders (xianglao 香老) (Figure 20).

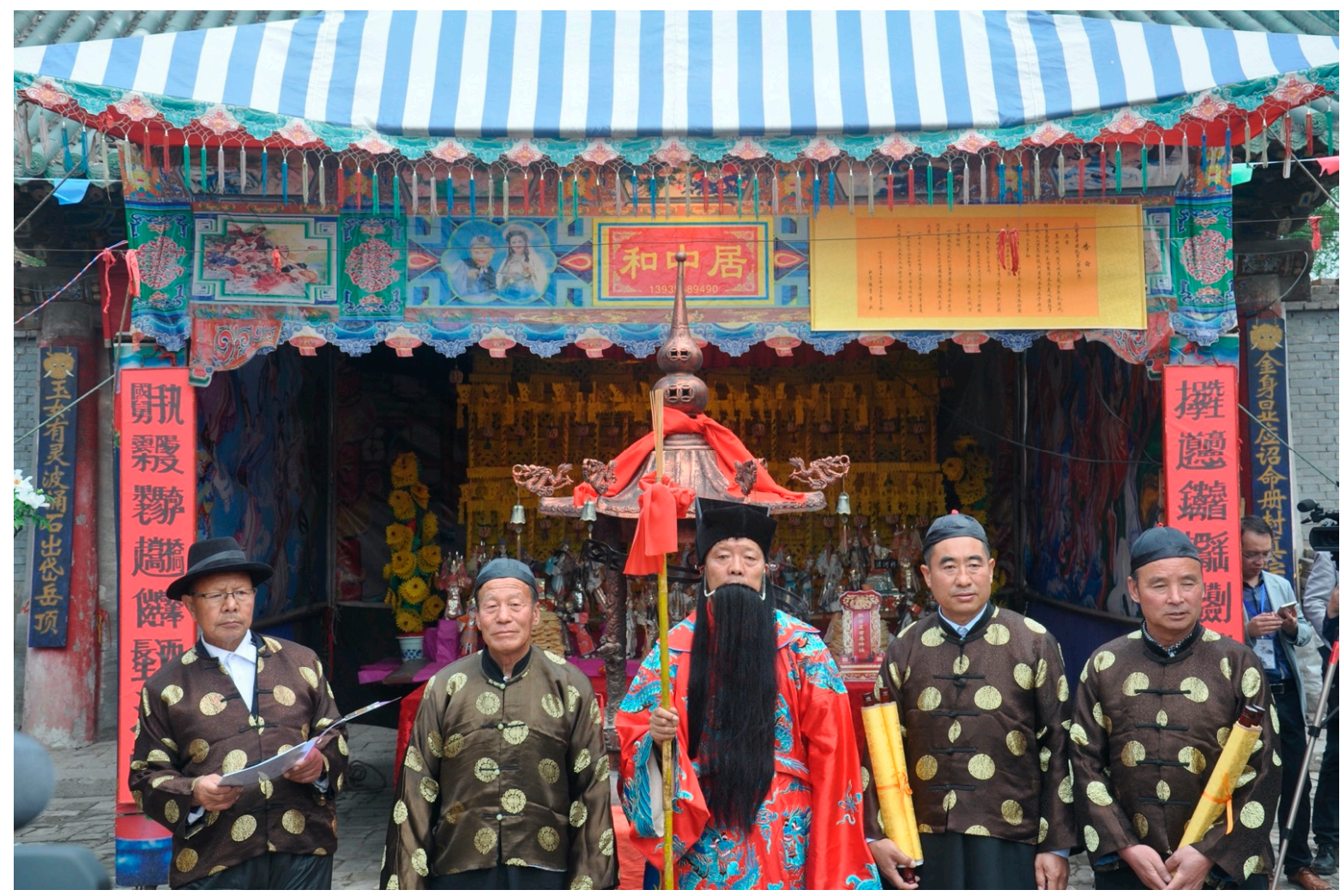

Figure 20. Jiacun Ritual leaders (left to right)—Du Tonghai: Chief Community Head and Chief Master of Ceremonials; Wei Qianxiu 衛前秀: Master of Ceremonials; Song Huaizhi 東懷支: Leader of Entertainment; Zhang Kaitai 張開泰 and Feng Chunsheng 馮春生: Incense Elders. 
The Chief Community Head is selected from among Community Heads (sheshou) and sometimes may concurrently act as the Chief Master of Ceremonials, as is the case with Du Tonghai. As the Chief Community Head, Du is the sai organiser, leader and director and, as such, he is also called the Chief Priest in Charge of Sacrifices (zhuji 主 祭); and as the Chief Master of Ceremonials, he is also charged with planning for and officiating at ritual performances (Du 2016). The Leader of Entertainers takes the lead in processional ritual performances, and this role is most of time ceremonial (Song 2016a). As shown above in Figure 20, the Leader of Entertainers wears a three-part long black artificial beard, a black gauze hat (wushamao 烏紗帽) and an embroidered jade girdle (yudai 玉帶, a hoop-shaped belt with jade ornaments) around the waist and costumes himself in a traditional ceremonial red silk robe embroidered with pythons (mangpao 蟒袍) as laosheng 老生 (lit. 'old man'), a major role type (jiaose 色) in traditional Chinese drama and theatre (xiqu 䖒曲) that often portrays an imperial official. Notably, the Leader of Entertainers holds a bamboo staff (zhuganzi 竹竿子) in all ritual performances he is involved in, so he is also called Master Bamboo Staff (zhuganzi). As for Masters of Ceremonials, this role is conventionally played by revered Yinyang Masters (yinyang shi 陰陽師, a diviner) or Fengshui Masters (fengshui shi 風水師, a geomancer also called kanyu jia 堪堹家) in the locality, whereas the role of Incense Elders is commonly assigned to village elders, who are also ritual specialists.

Another prominent figure active in the village festival is Mapi 馬正 or Mabi 馬裨, a spirit-medium who used to have both cheeks pierced with a 15 to $20 \mathrm{~cm}$ long steel pin (kouqian 口釬) while performing trance séance in Shangdang village festivals. According to Song Yusheng 尔玉生 (2016), the Mapi of Jiacun, the main responsibility of Mapi is to provide assistance in the ritual of offering sacrifices and help maintain order in processions during temple festivals (Figures 21 and 22). ${ }^{38}$

Also essential to the temple festival are a troupe of professional actors and musicians from the Registered Households of Entertainers (yuehu 樂戶) and the Chief Ritual Chefs (zhuchu 主㕌), the former playing ritual music and performing dance and drama during the festival, and the latter preparing elaborate food offerings and arranging them in an extremely intricate pattern (chaji 插祭) (Figure 23) in a colourfully decorated shed called the 'Incense Pavilion' (xiangting 香亭) (see Figure 20).

As a traditional saying goes in Shangdang, 'Engaged in competition (sai) with each other in a big temple festival (sai) ${ }^{39}$ are three groups of people: tortoises (wangba王八), chefs and yinyang masters.' While the saying contains the word wangba as a derogatory term for ritual Entertainers or yuehu, ${ }^{40}$ it reveals the instrumental role of these three groups of people in temple festivals in the Shangdang region. A Registered Household of Entertainers is usually affiliated with one or more ritual communities (she) to perform at temple festivals, although they also perform in domestic ceremonies such as funerals, weddings and anniversaries. Traditionally affiliated with the three Jiacun Worship Associations is the Assembly of Eight Sounds' (Bayin hui八音會) (Figure 24), headed by Wang Jinzhi 王 進枝 (Figure 25), the eighth-generation inheritor of the Wang Registered Household of Entertainers of Xiliu 西流, a village about twenty-five kilometres northeast of Jiacun (Wang 2016a).

Village festivals also involve various ritual attendants and assistants such as Carriers of Spirit Tablets (tingzi 亭子), Carriers of Food Offerings in the Courtyard (tingzi 庭子), Canopy-Holders (weizi 帷子), Escorts of Offering Cups (yazhan 押盈), Incense Elders ( $x i$ anglao 香老), Incense Masters (sixiang 司香), Tea Masters (sicha 司茶), Wine Masters (sijiu 司 酒), Candle Masters (sizhu 司蟀), Water Attendants (shuiguan 水倌), Banner-Holders (zhiqi 執旗), Umbrella-Holders (sanfu 绊夫), Carriers of Sedan Chairs (jiaofu轎夫) and Ceremonial Guards (yizhang 儀仗). Apart from them, there are also numerous procurement personnel (caimai 採買) and odd-jobbers (qinza 勤雜) involved in the festivals. 


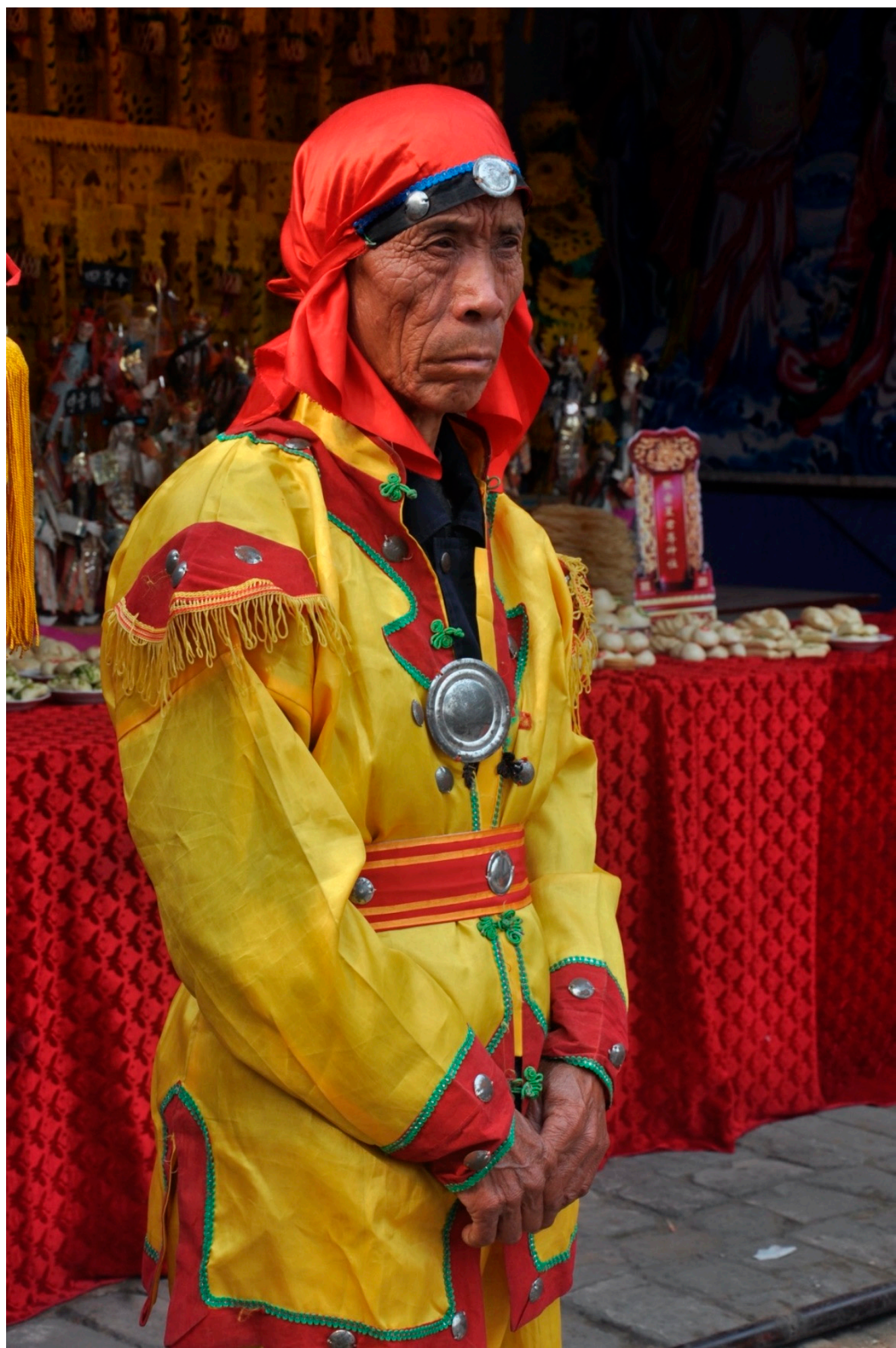

Figure 21. Song Yusheng Who Plays Mapi in Jiacun Temple Festivals. 


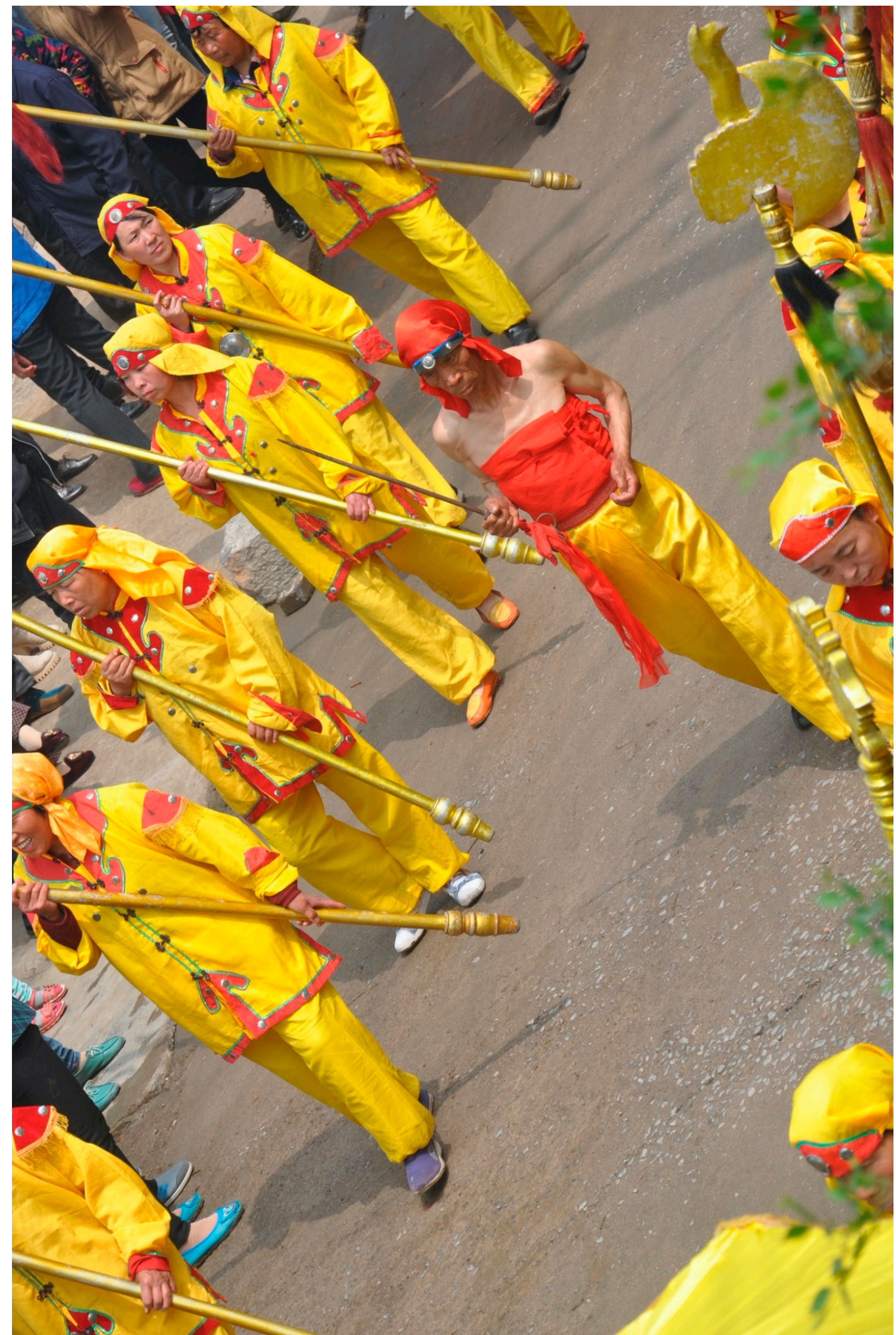

Figure 22. Mapi in Procession. 


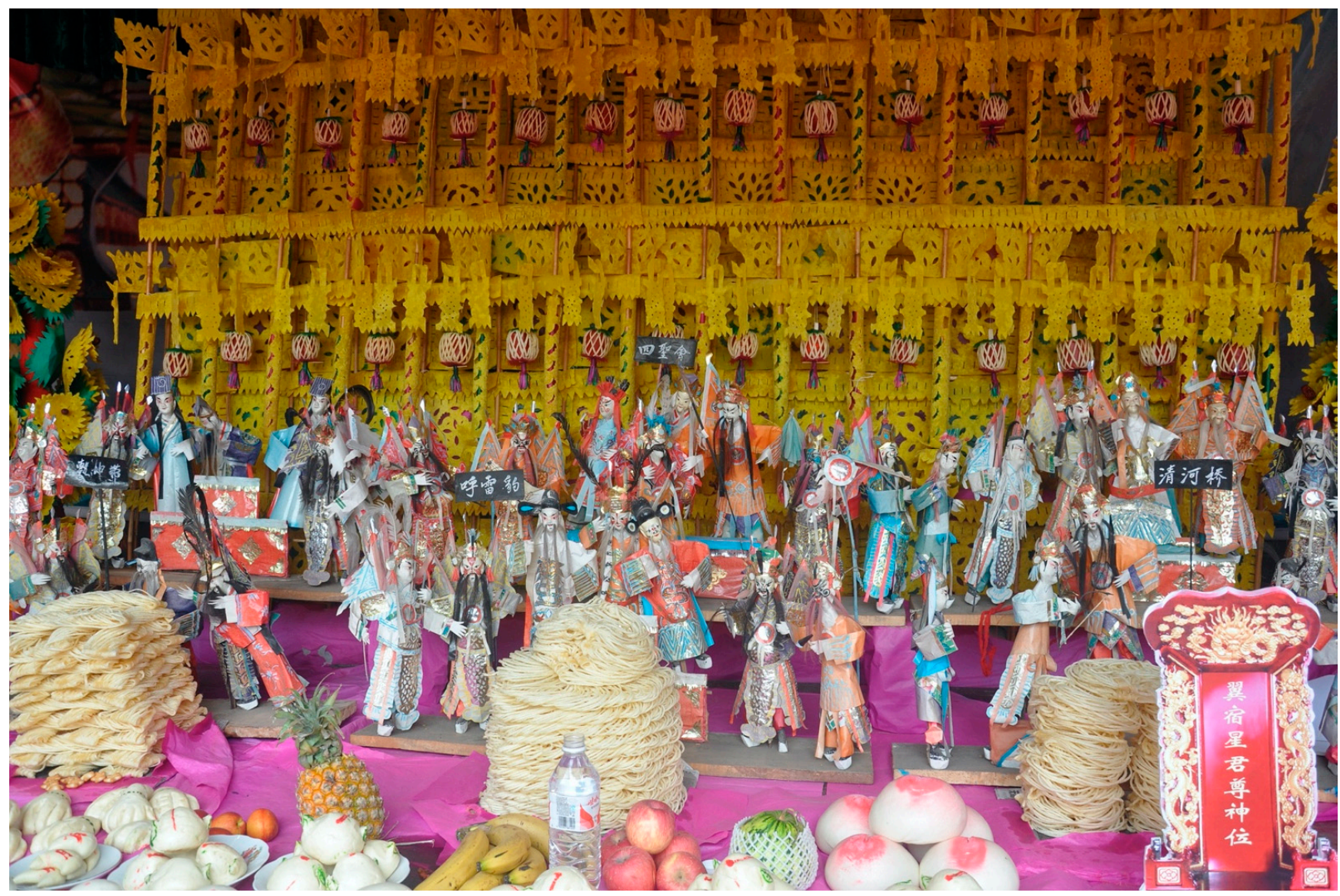

Figure 23. Food Offerings in the Incense Pavilion.

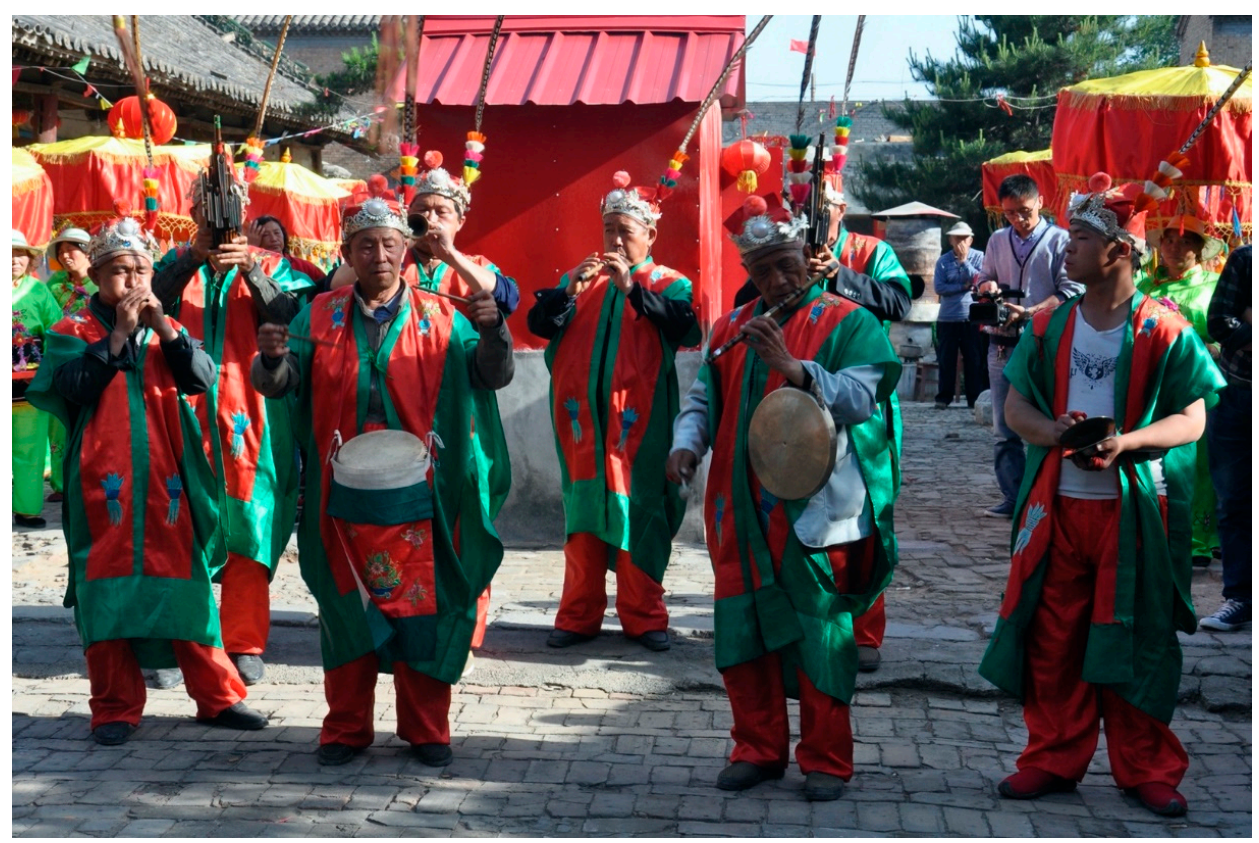

Figure 24. The Assembly of Eight Sounds from Xiliu Village. 


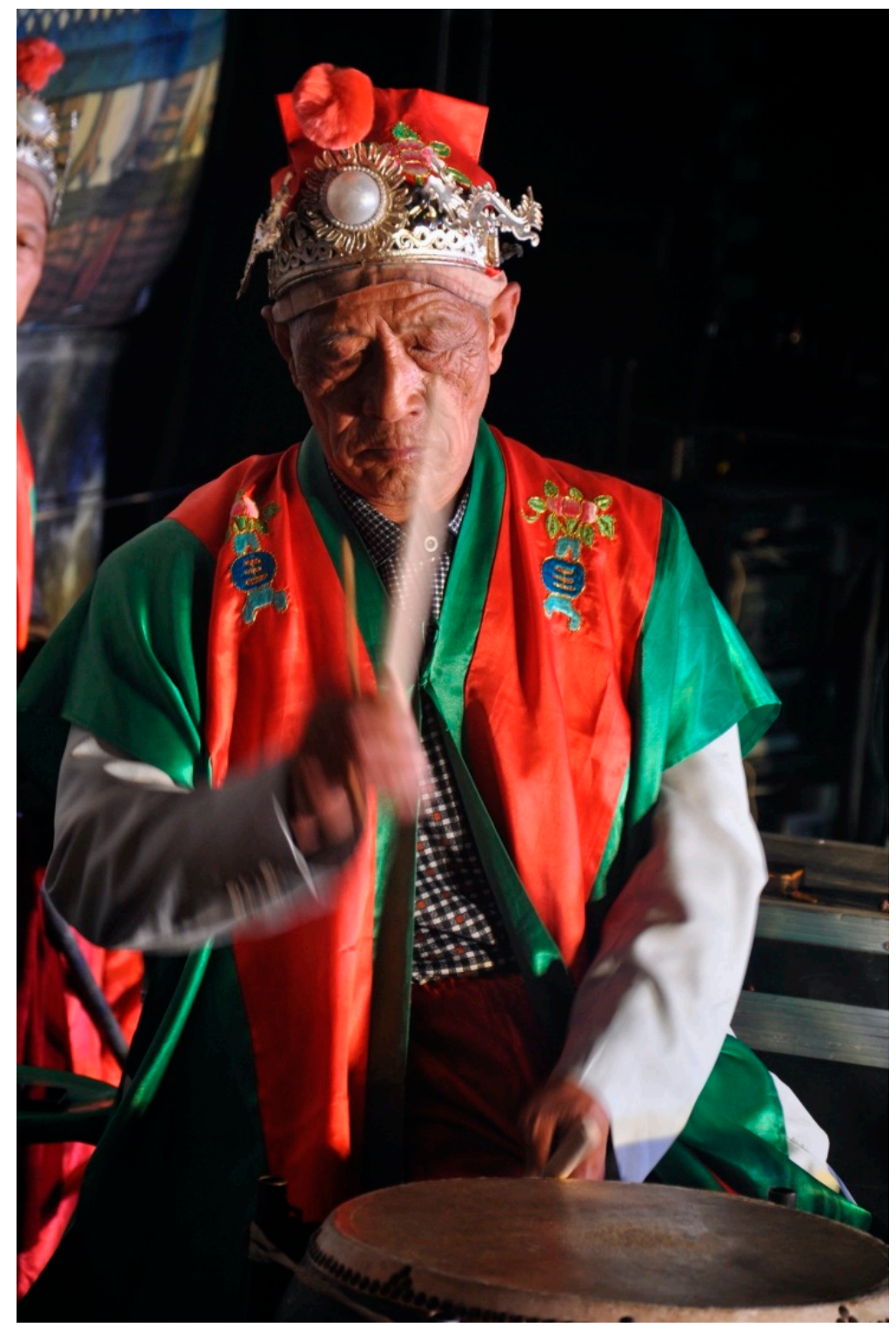

Figure 25. Wang Jinzhi, Head of the Assembly of Eight Sounds from Xiliu Village.

\section{Jiacun Double-Fourth Temple Festival}

The year 2016 was a year for small sai. The normal length of small sai is three days, which, however, was shortened to two and a half days in 2016, with the celebration beginning on the morning of the third day of the fourth month (9 May) and running until the noon of the fifth day of the fourth month (11 May), although the festival still followed a standard tripart format, i.e., welcoming, entertaining and seeing off gods, which are locally referred to as the initial sai (tousai 頭賽), the main sai (zhengsai 正賽) and the final sai (mosai 末賽), respectively. The first day of the temple festival was devoted to the initial sai, with the main sai and final sai scheduled, respectively, for the morning and afternoon of the second day, followed by a special concert performance by the Entertainers on the morning of the third day.

The initial sai consists of a series of rituals-namely, Inviting the Deities to Descend (xiaqing 下請), Welcoming the Deities (yingshen 迎神), Assembling All the Deities (yuan-shen 圓神), Dismounting Horses (xiama 下馬), Receiving the Deities (jieshen 接神) and Settling the Deities (anshen 安神). The ritual of Inviting the Deities is also called 'the Assembly for Offering Incense' (Shanxiang hui 上香會) in the Shangdang region, in which the principal 
god of the sai festival invites through the local Earth God all other deities and spirits worshipped by members of a ritual community to receive sacrificial offerings and enjoy musical and theatrical performance at the host temple of the sai festival. In the case of the Double-Fourth Temple Festival in Jiacun, Bixia yuanjun plays host to the sai festival as the principal deity of the Bixia Temple.

\subsection{The Initial Sai: Morning Session}

The ritual of Inviting the Deities took place very early on the morning of the third day of the fourth month in the Bixia Temple. Before daybreak, hundreds of people gathered in the temple around Du Tonghai, Song Huaizhi and other ritual leaders. Among them were an ensemble of eight wind and percussion musicians from the Assembly of Eight Sounds and an army of Guards of Honour, Carriers of Spirit Tablets and Canopy-Holders, among others.

The ritual started with a formal announcement by Du Tonghai, the Chief Master of Ceremonials: 'I declare open the Jiacun Double-Fourth Temple Festival, celebrating the birthday of the Primordial Sovereign of the Morning Clouds. Sound the golden bell and beat the drum; All be ready to perform their respective duty!' (Figure 26).

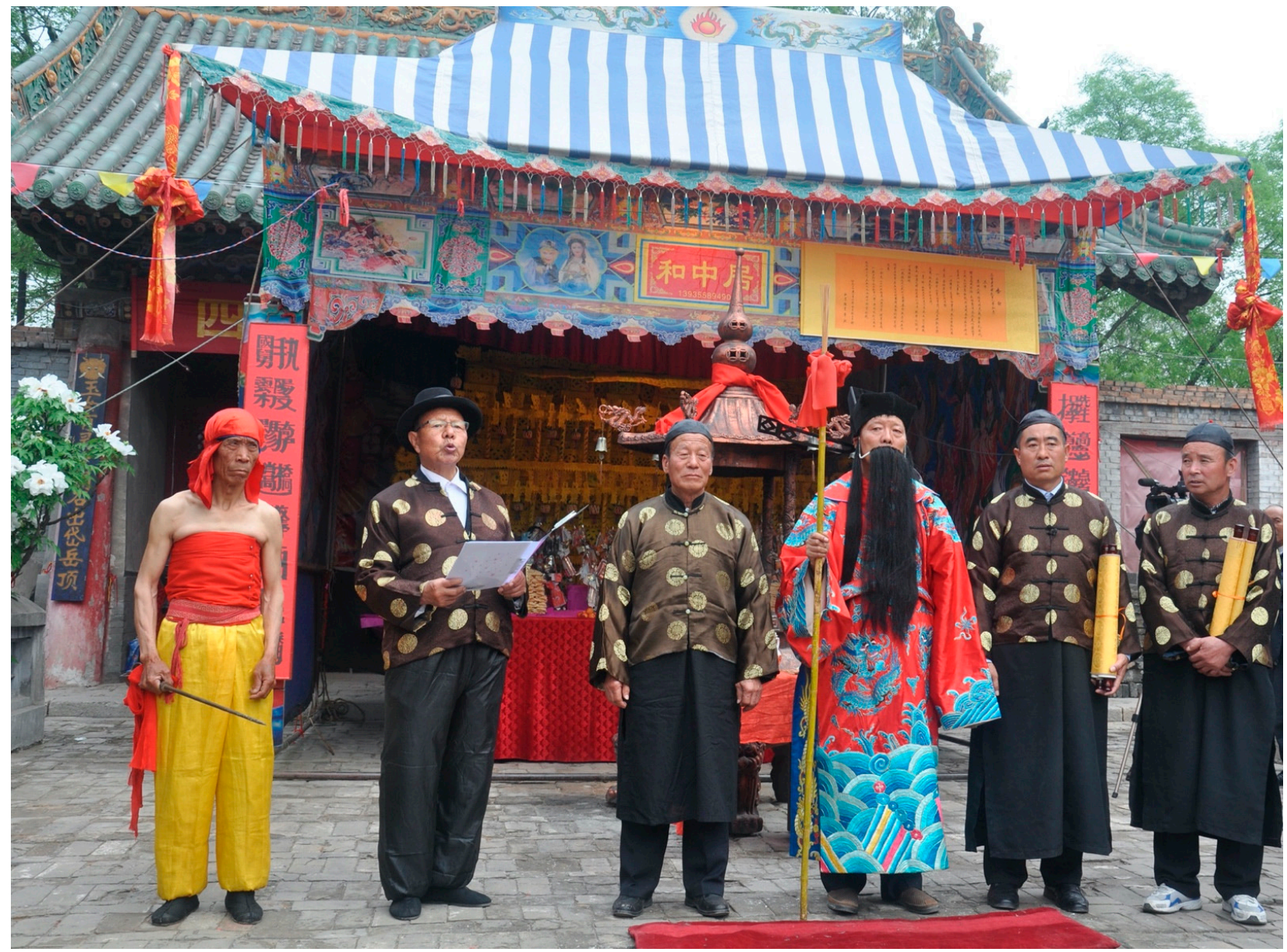

Figure 26. Du Tonghai Chief Head Community/Chief Master of Ceremonials Announces the Opening of Jiacun DoubleFourth Temple Festival. 
No sooner had he finished the opening declaration than came three beats of a big gong and then another three beats of a big drum, followed by 'Open the Door Wide' (Dakaimen 大 開門), a piece of suona 唄呐 or shawm music performed by the Entertainers under the direction of Master Bamboo Staff. The ritual leaders circled the Incense Pavilion three times. Also called the 'Offering Pavilion' (xianting 獻亭) and 'Divine Shed' (shenpeng 神棚), the Incense Pavilion was a canopied tabernacle temporarily built in front of the main hall to house a display of 'arranged flowers for the altar' (chaji 插祭/ huaji 花祭) with food offerings neatly piled on a large offering table against a floor-to-ceiling framework decorated with seasonal flowers and painted clay figurines of famous characters in traditional drama. The food offerings are made of wheat paste-hence their alternative name of 'flour offerings' (mianji 面祭). They are cut into fine-looking shapes and deep fried until golden brown and put on display in the Incense Pavilion (Figure 23). ${ }^{41}$ The Incense Pavilion served as the centre for ritual performance during the temple festival (see Figure 26). In front of the Incense Pavilion stood an altar with sprit tablets and food and fruit offerings (Figure 27).

After the ear-piercing suona music stopped, Du Tonghai, the Chief Master of Ceremonials, invited Feng Chunsheng and Zhang Kaitai, the two Incense Elders, to perform the ritual of offering incense (shangxiang 上香). While Feng walked up to offer incense, Zhang unfolded the 'Writ of Offering Incense' (shangxiang wen 上香文) ${ }^{42}$ (Figure 28), and at the same time, all other ritual participants knelt down to listen to him reciting the text. After he finished reading the text, Wei Qianxiu, the Master of Ceremonials, took a cup of wine from Mapi and poured it on the ground (Figure 29). Next came a long prayer said by Du, the Chief Community Head, of grateful thanks to Bixia yuanjun on behalf of the three worship associations of the village.

After offering the incense, Master Bamboo Staff, Song Huaizhi led the other ritual leaders out of the Bixia Temple to the Earth God Temple, followed in processions by Vanguards, Entertainers, Ceremonial Guards, Banner-Holders, Umbrella-Holders, Rearguards, etc. The grand procession wound its way slowly through the streets and lanes of the village to the Earth God Temple, which was located in the northwestern corner of the village. At the front were two men dressed as yamen runners in premodern times, beating gongs to clear the way for the parade, followed by the ritual leaders, flanked by processional placards and banners (Figure 30) and accompanied by a small wind and percussion band formed by members of the Assembly of Eight Sounds (Figure 31).

When the procession arrived at the Earth God Temple, Du Tonghai took a step forward and made a deep bow, announcing, 'Let sacrifices be offered to the Gate; let incense be lit and presented; let music be performed; let us all kneel to kowtow thrice [to the Earth God].' He then went a few steps up to the door and knocked on it to the suona music of 'Open the Door Wide'. The door opened inward, and the ritual of offering incense, singing prayers, pouring wine, kneeling and kowtowing was performed to the accompaniment of 'Drumming for Offering Incense' (Shangxiang gu 上香鼓). Again, each of the actions was repeated three times, and after that, Du chanted the 'Writ of Invitations' (Qingzhuang wen 請狀文), by which formal invitations were extended on behalf of the Earth God to all gods and spirits of the village to attend the celebration of the birthday of Bixia yuanjun in the Bixia Temple. After finishing reading the writ, he set it alight and placed it in the incense burner. Seeing it burnt to ashes, he signalled the Entertainers to play the 'Melody for Worshipping the Drum' (Baigu qu 拜豉曲) to 'conclude the ritual of making offerings' (zhongxian li 終獻禮) at the Earth God Temple. The procession then returned to the Bixia Temple, retracing the earlier route through the village.

Before they passed through the entrance hall of the temple, a ritual called 'Offering Sacrifices to the Gate' (Jimen 祭門) was performed to the music of 'Open the Door Wide', which was followed by the ritual of offering incense and wine and that of kneeling and kowtowing held in front of the Incense Pavilion to the 'Melody for Worshipping the Drum', hence the end of the ritual of 'Inviting the Deities to Descend'. 


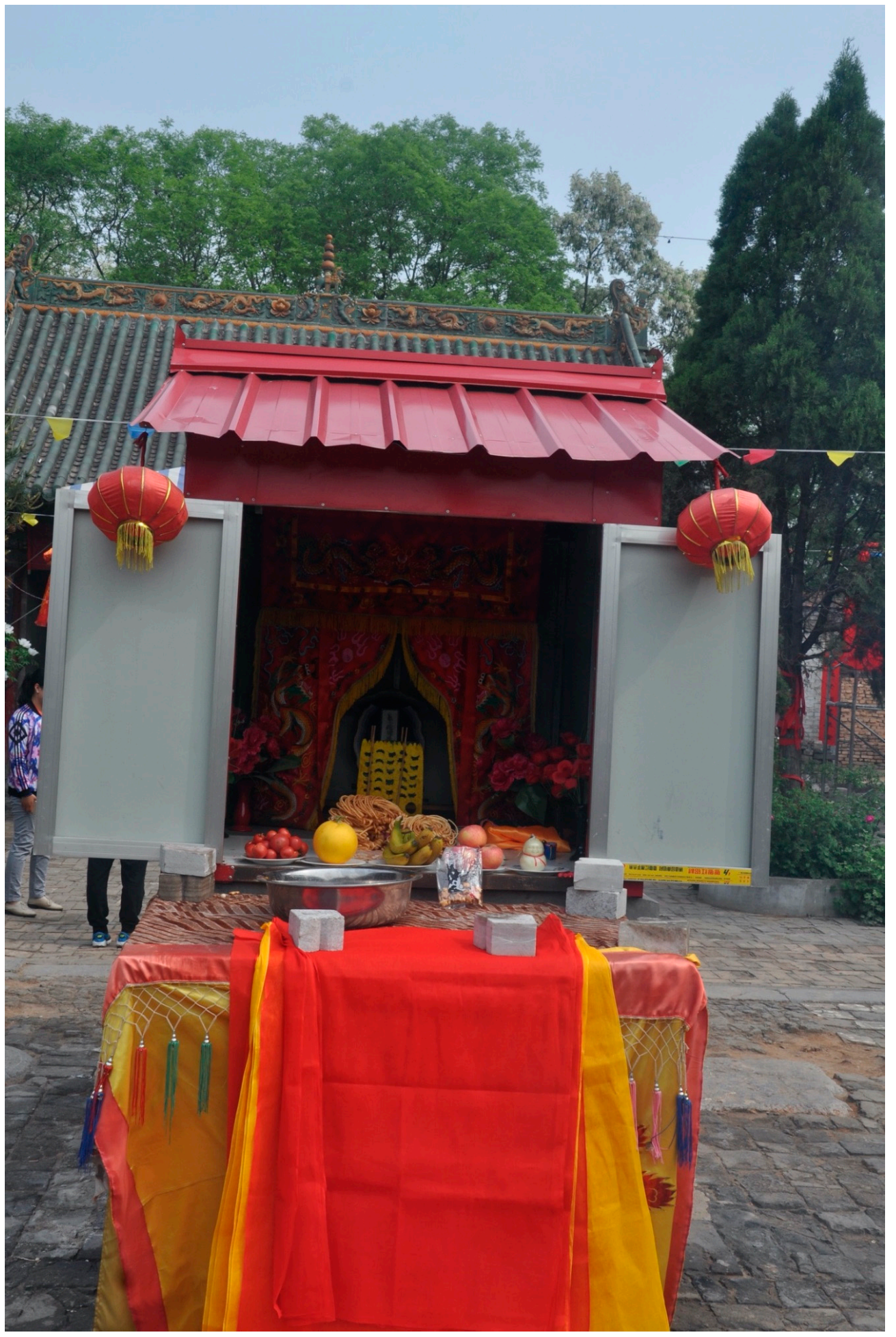

Figure 27. Altar with Sprit Tablets and Food and Fruit Offerings. 


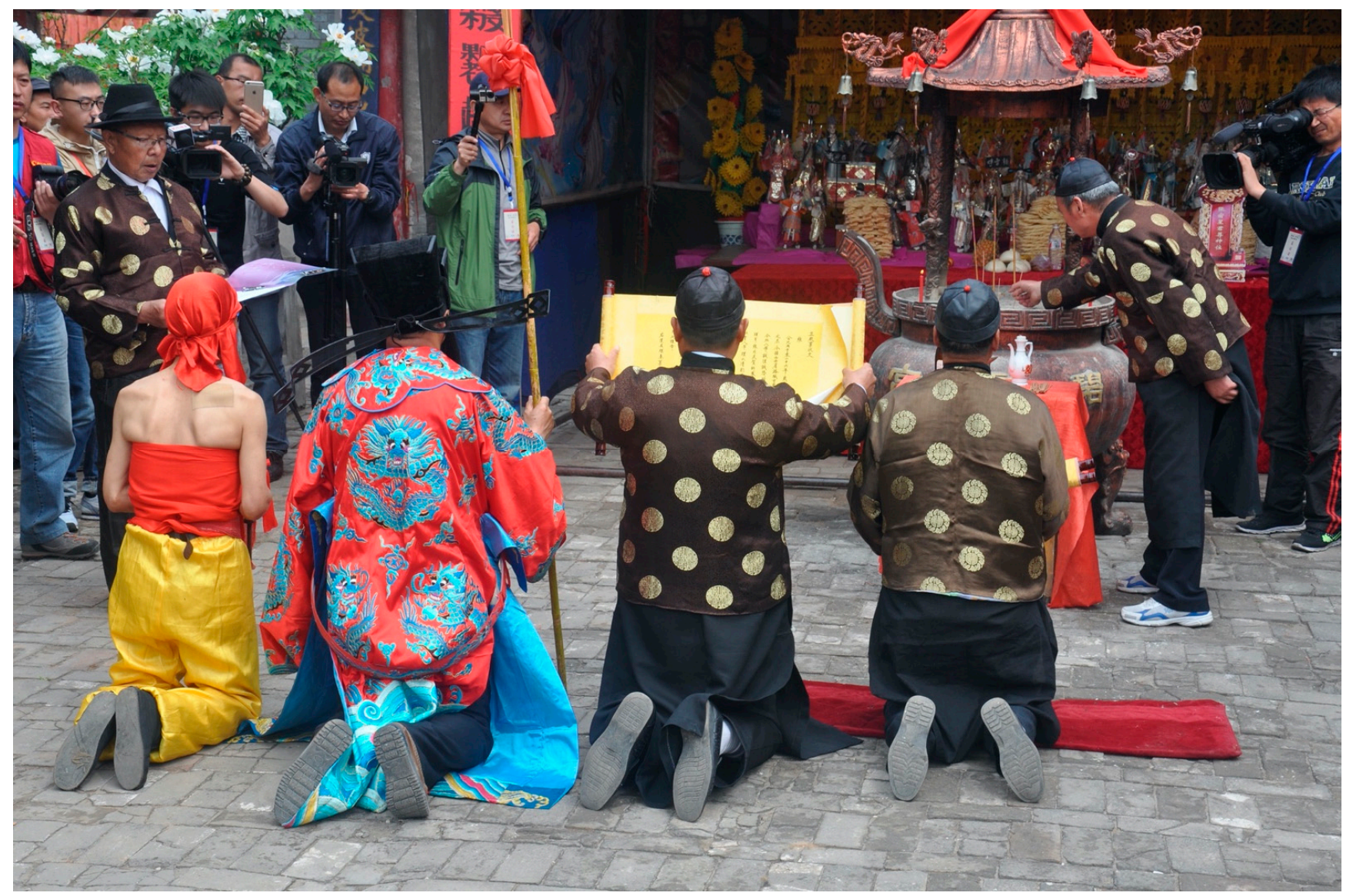

Figure 28. Offering Incense.

Next came the ritual of 'Welcoming the Deities'. Also called 'Fetching the Deities' (jieshen 接神), 'Welcoming the Deities' was a large-scale shehuo performance that involved the parading of the image (xingixang 行像) of Bixia yuanjun through the village. The ritual started around 9:30 a.m. with the musical performance of 'Fetching the Deities' presented by the Entertainers in front of the Incense Pavilion (Figure 32) as a prelude to the 'Writ of [Requesting the Deities to] Mount Horses' (Shangma wen 上馬文) recited by Du Tonghai, the Chief Master of Ceremonials. The Entertainers followed Du and other ritual leaders out of the temple to the Divine Pool, where a gigantic procession, all dressed in flamboyant costumes, had already formed up. The two men who were dressed as yamen runners walked ahead of all others, and they were the first to emerge from the gateway of the temple, beating the gong to clear the way (Figure 33).

Right adjacent to the Divine Pool was Cundong 村東 Road, the main street in Jiacun that ran from north to south through the village. The procession set off for the Yuhuang miao or the Jade Emperor Temple, which was located approximately seven hundred metres northwest of the Bixia Temple. They walked northwards along the main street until they came to a crossroads where stood the Guanyin Pavilion (Figure 34), through the gateway of which ran a thoroughfare linking the Eastend and Westend of Jiacun. The section of the through road on the eastern (right) side of the Pavilion was Gedong 閣東 Road, and that on the western (left) side was Gexe 閣西 Road, which led to the Jade Emperor Temple about three hundred metres due west of the Guanyin Pavilion (Figure 35). 


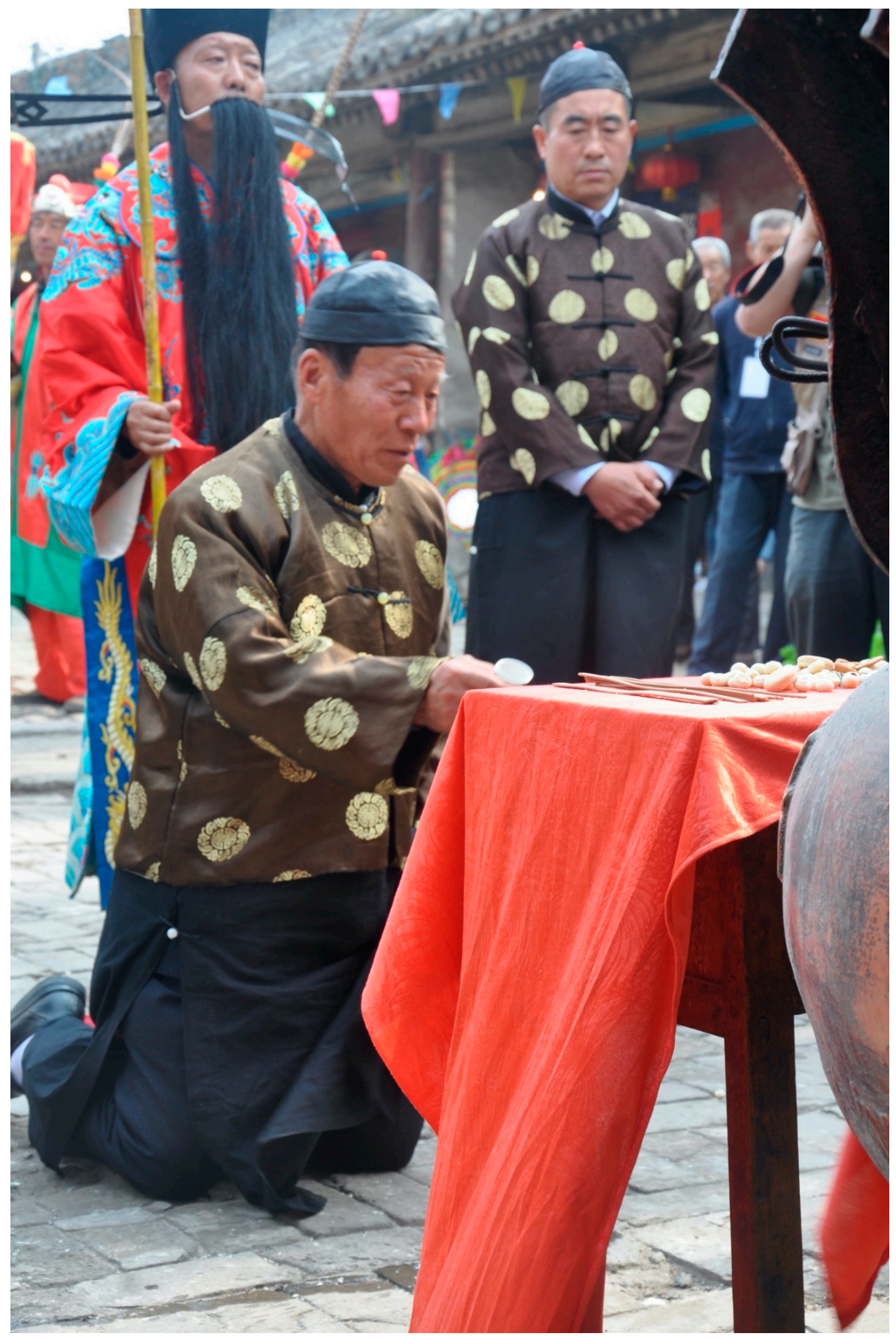

Figure 29. Wei Qianxiu, the Master of Ceremonials, Pours Wine Before the Offering Table. 


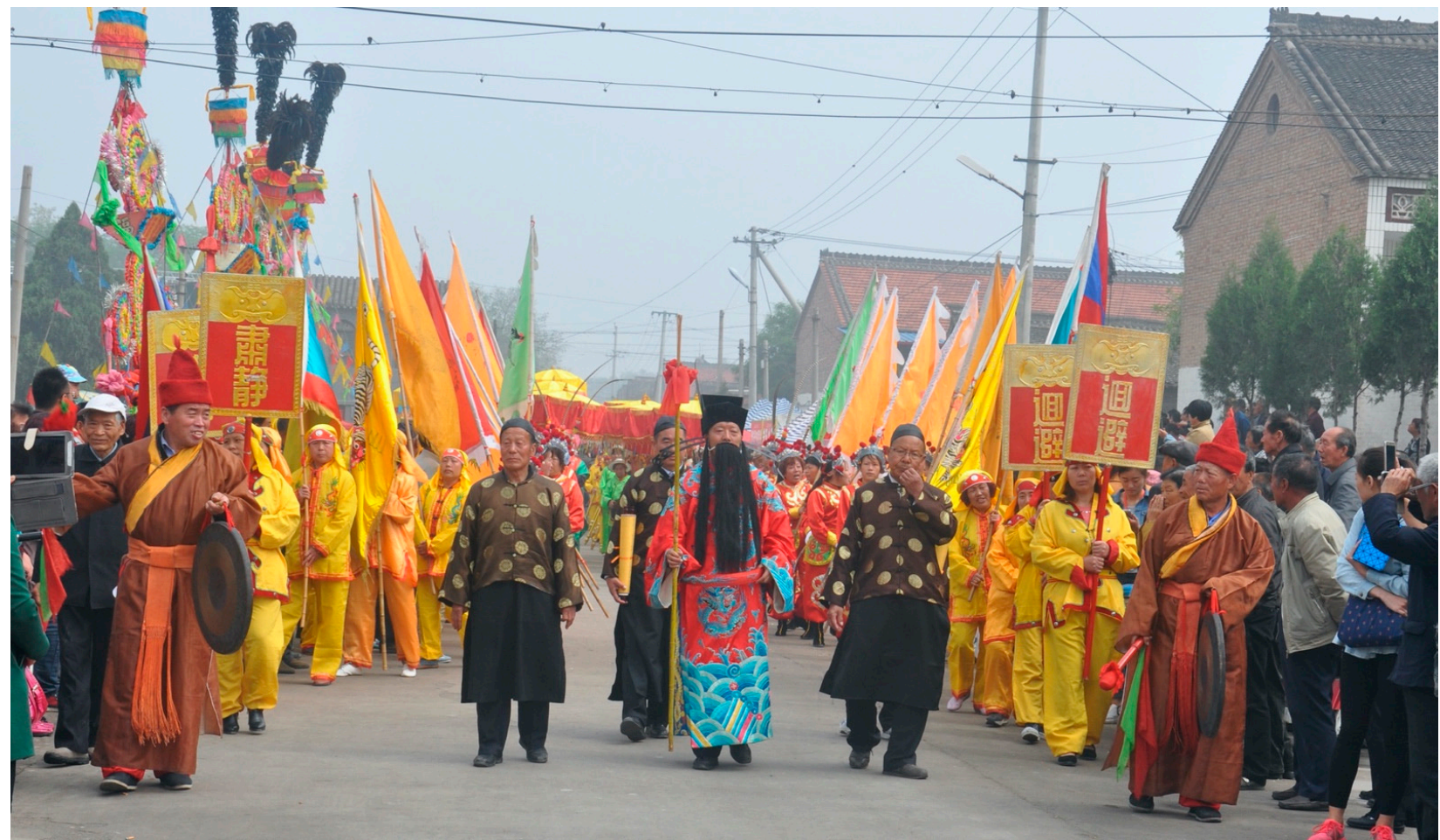

Figure 30. Yamen Runners Beat Gongs to Clear the Way for the Procession Headed by Master Bamboo Staff and Other Ritual Leaders.

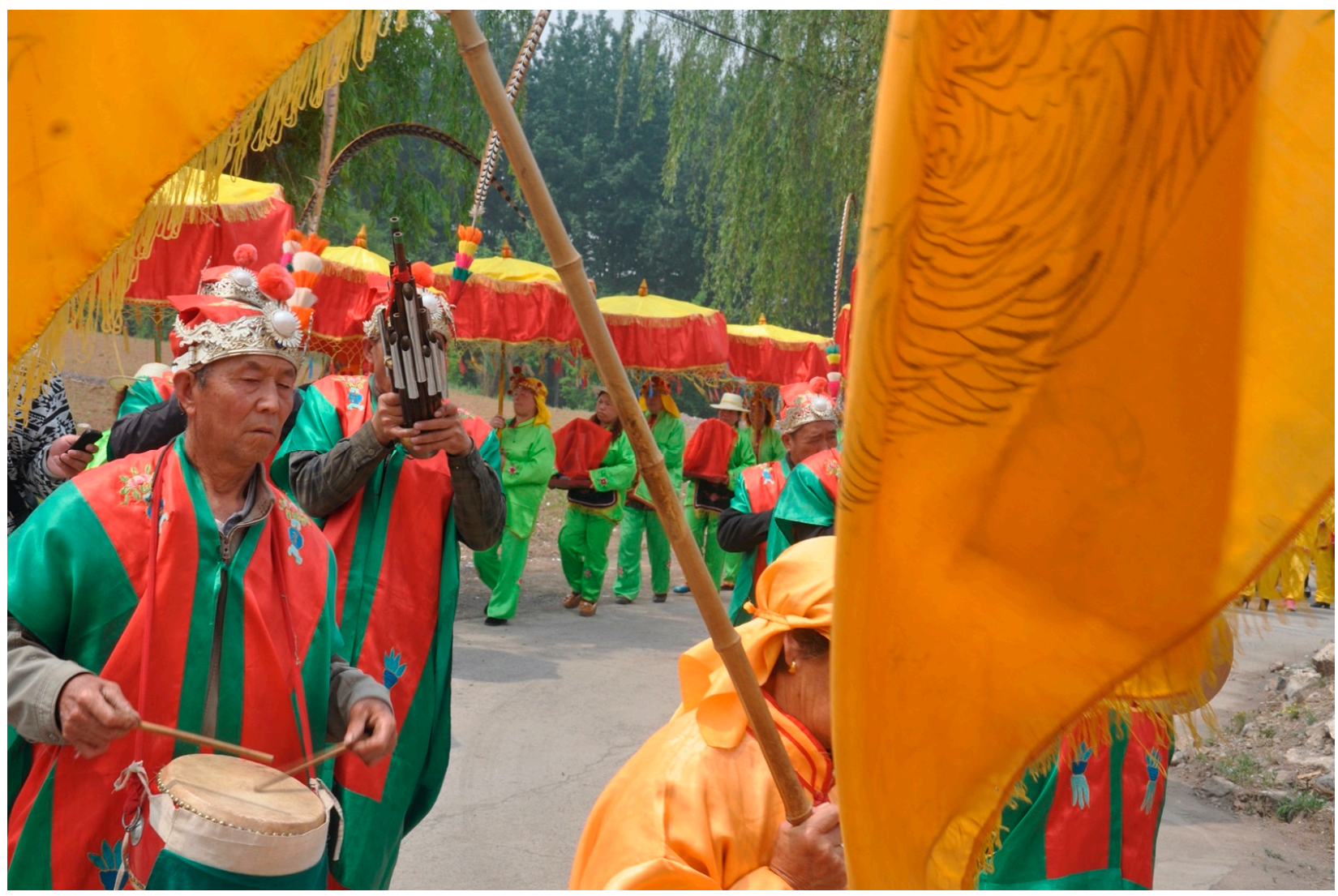

Figure 31. Entertainers Play Music to Accompany the Procession. 


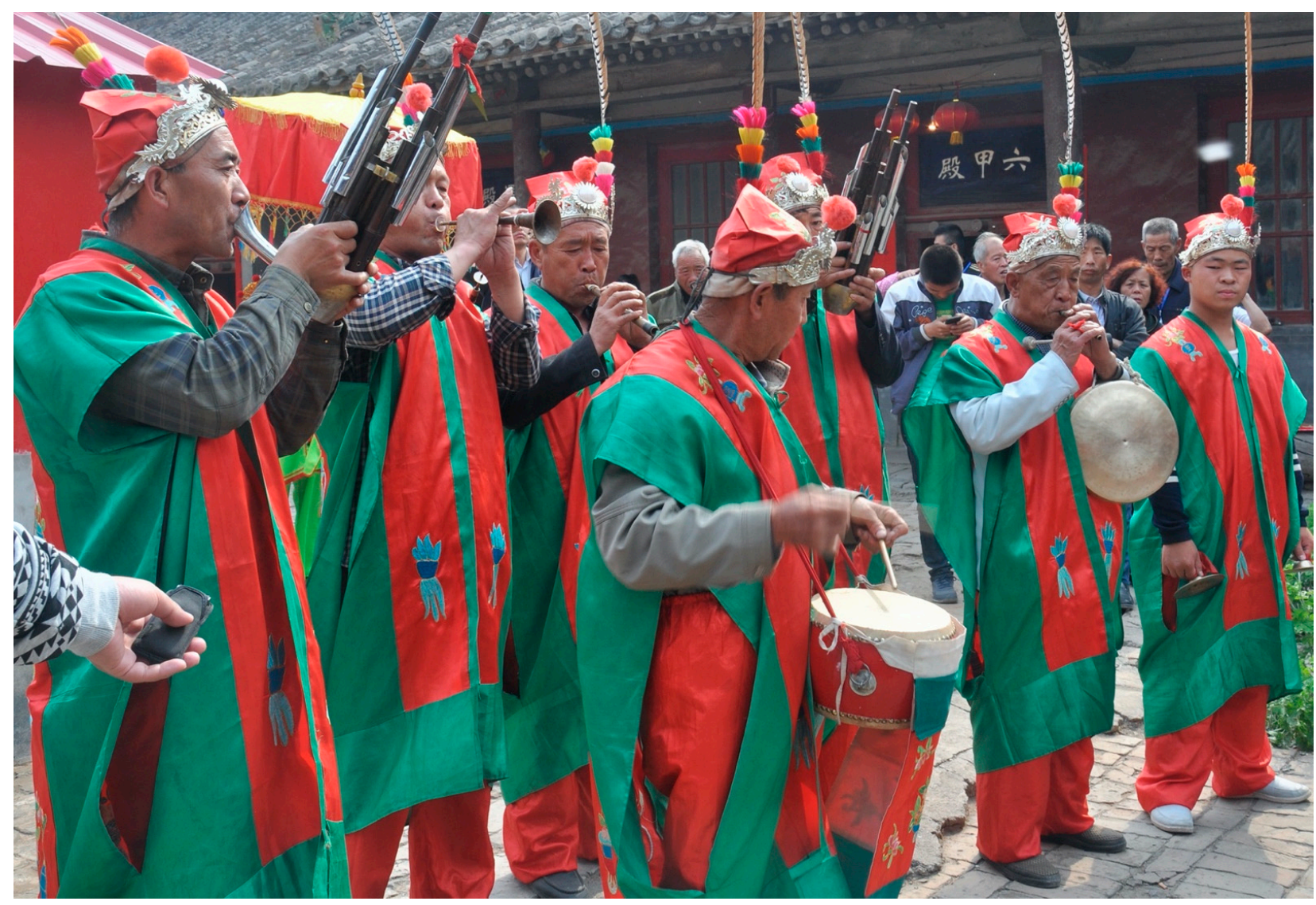

Figure 32. Entertainers Perform 'Fetching the Deities'.

When they arrived at the Jade Emperor Temple, there were ritual performances of opening the door, offering incense, pouring wine, praying, kneeling and kowtowing presented in the same way as I had observed earlier at the Earth God Temple (Figure 36).

After that, the Jade Emperor was carried out in a sedan chair with a golden cover on top adorned with a pair of golden dragons (Figure 37) to meet the Primordial Sovereign of the Morning Clouds who was waiting in her sedan chair parked outside at the entrance from the road. The sedan chair for the goddess showed no difference from that of the god except that its top was adorned with a pair of emerald green phoenixes (Figure 38). The dragon stands for yang, the phoenix yin in fengshui, so they make a perfect match.

The procession to the Divine Arena for the Assembly of All Deities (yuanshen chang 圓 神場) began when all participants were lined up outside the Jade Emperor Temple along the way they had come from. The procession route was lined four to five deep by thousands of people from neighbouring villages and towns, all eager to get a good view of the street performance (Figure 39). When they came to the crossroads, they stopped to be joined, first by twenty-four tingzi, all female, each carrying a spirit tablet with the name of a god inscribed on it, next by four Divine Carriages (shenjia 神駕) $)^{43}$ carrying the Dragon Kings of the Four Seas (Sihai longwang 四海龍王), and then by gods and goddesses that frequently appear in xiqu such as the Eight Immortals and Lord Guan. These mythological and legendary characters were played by the Entertainers. Some of them were riding horses, some walking on foot, and while proceeding down the north-south avenue to the Divine Arena, they made stylised movements and gestures as if performing drama onstage. One could easily tell what dramatic characters or roles they represented from their props, cosmetics, costumes, movements, gestures and facial expressions. These deities were all invited by Bixia yuanjun to attend the celebration of her birthday. Among them, the most distinguished was the Jade Emperor. In front of each group of divine beings were young men carrying flags bearing the paper cut-outs of 'divine mansions' (shenou 神樓) 
and 'divine horses' (shenma 神馬), followed by a small music troupe with gongs and drums, and at the rear were young women carrying ceremonial parasols and banners.

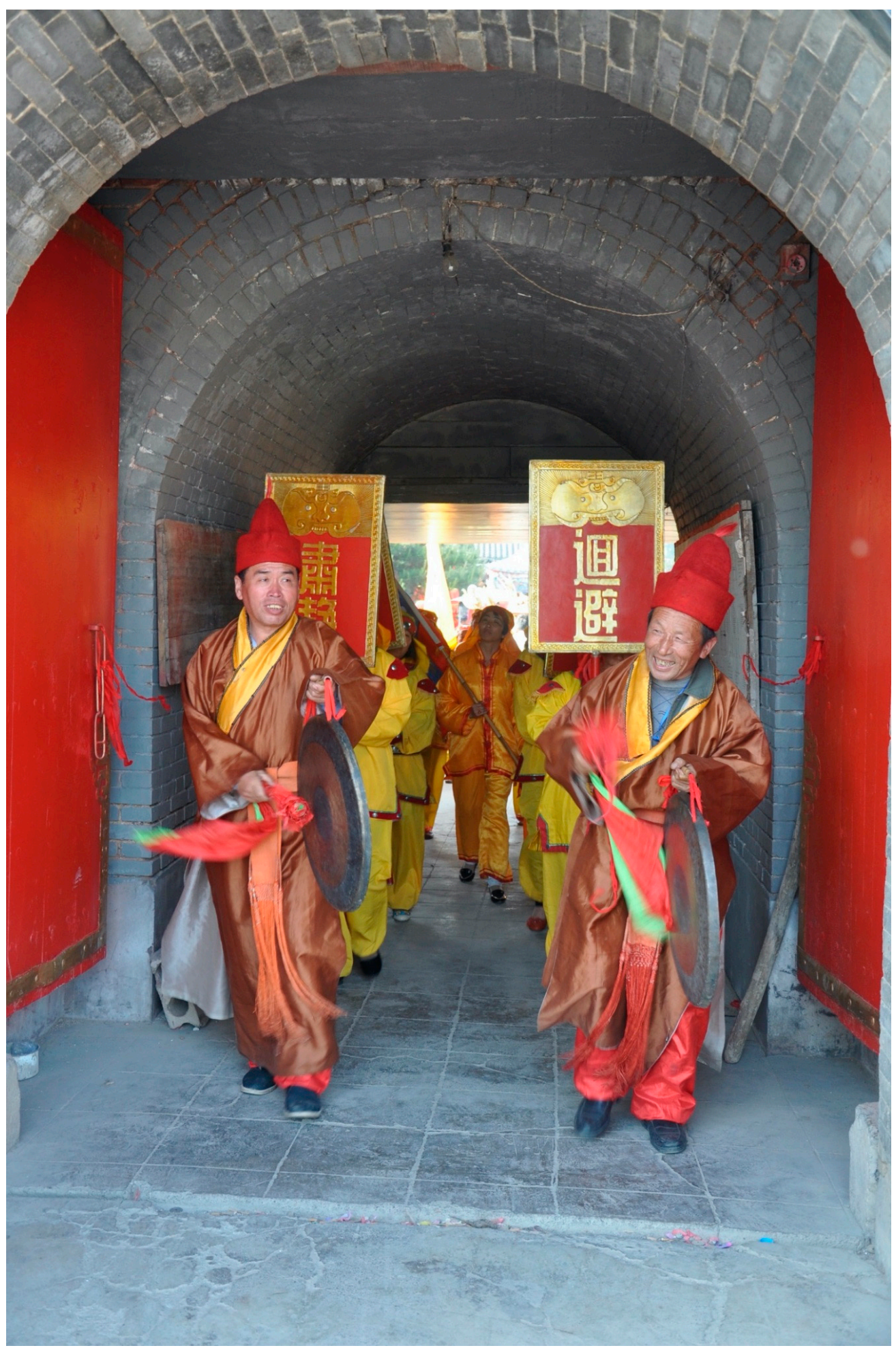

Figure 33. Yamen Runners Emerge from the Gateway. 


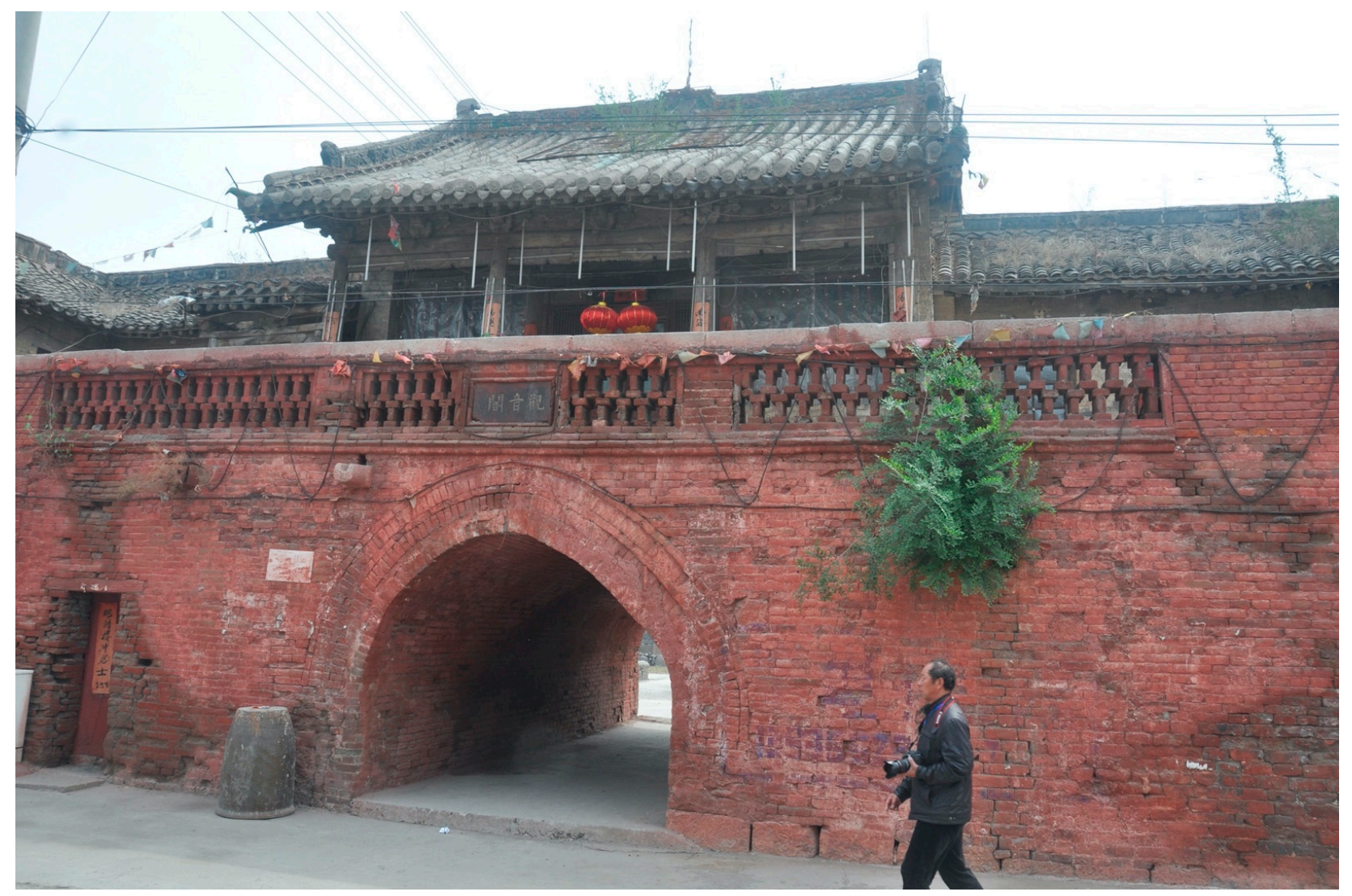

Figure 34. Gatehouse of Guanyin Pavilion.

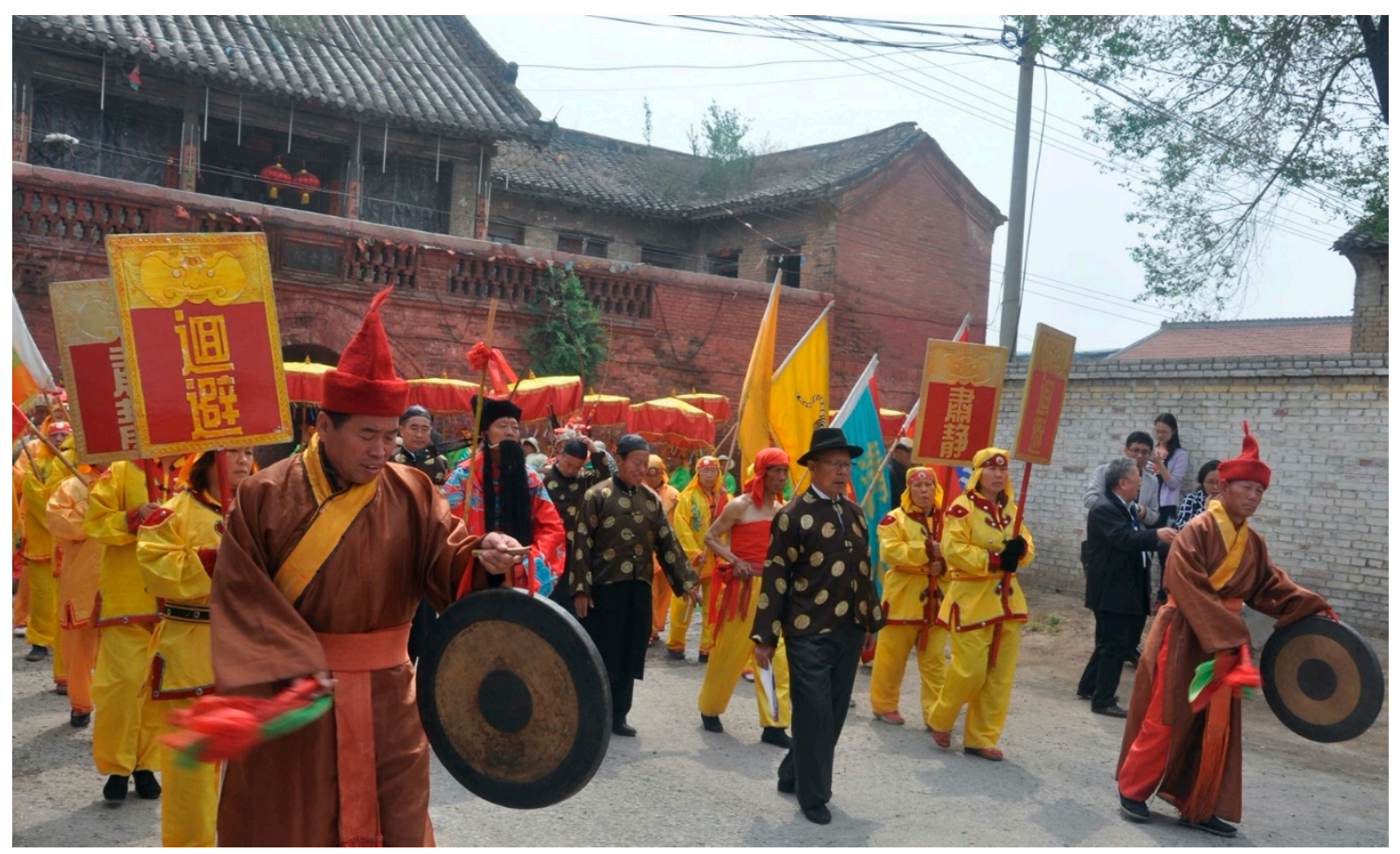

Figure 35. The Procession Turns Left at the Crossroads, Heading for Jade Emperor Temple. 


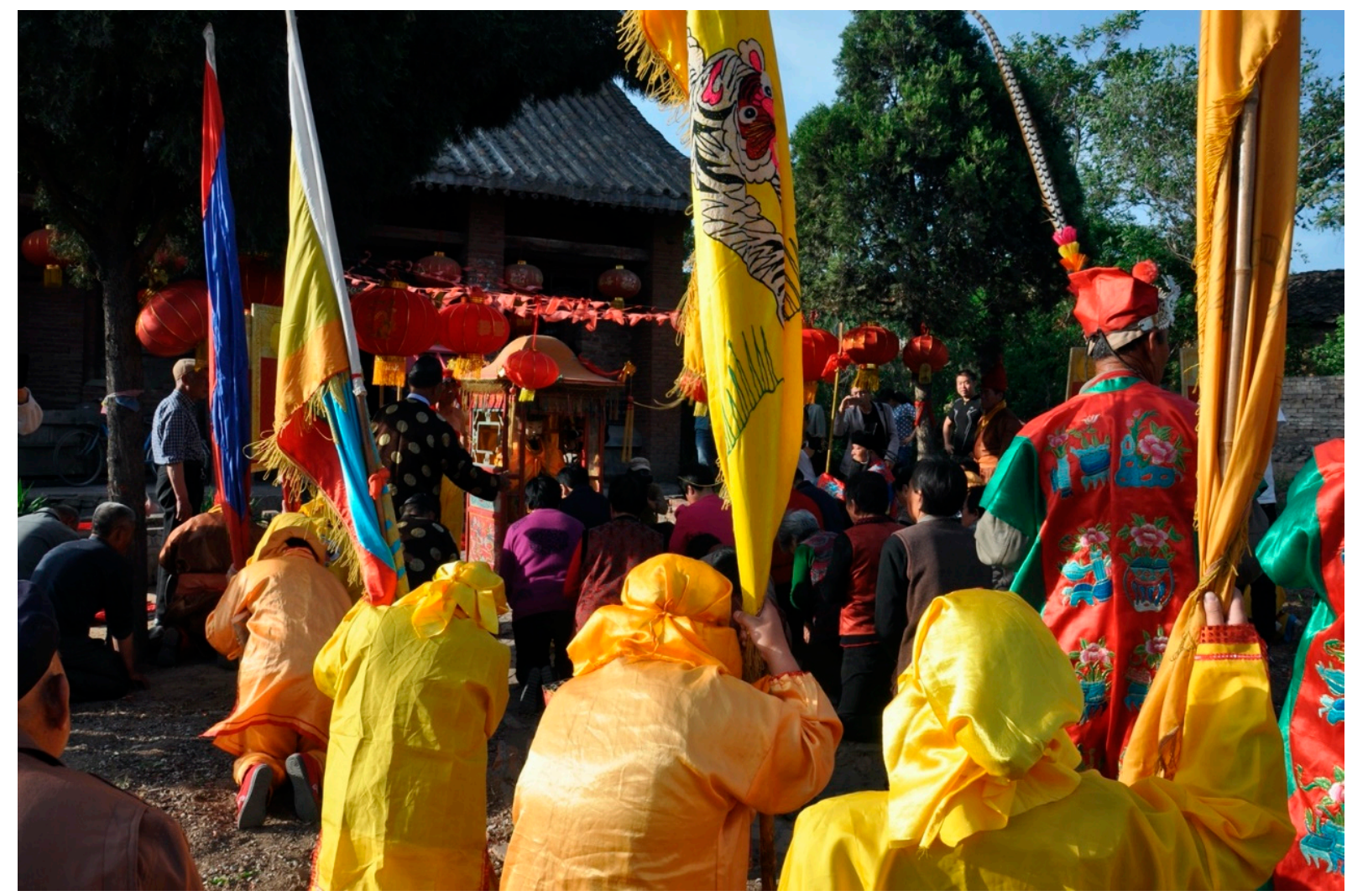

Figure 36. Villagers and Ritual Participants Kneel Down to Wait for Jade Emperor to Be Carried Out of His Temple.

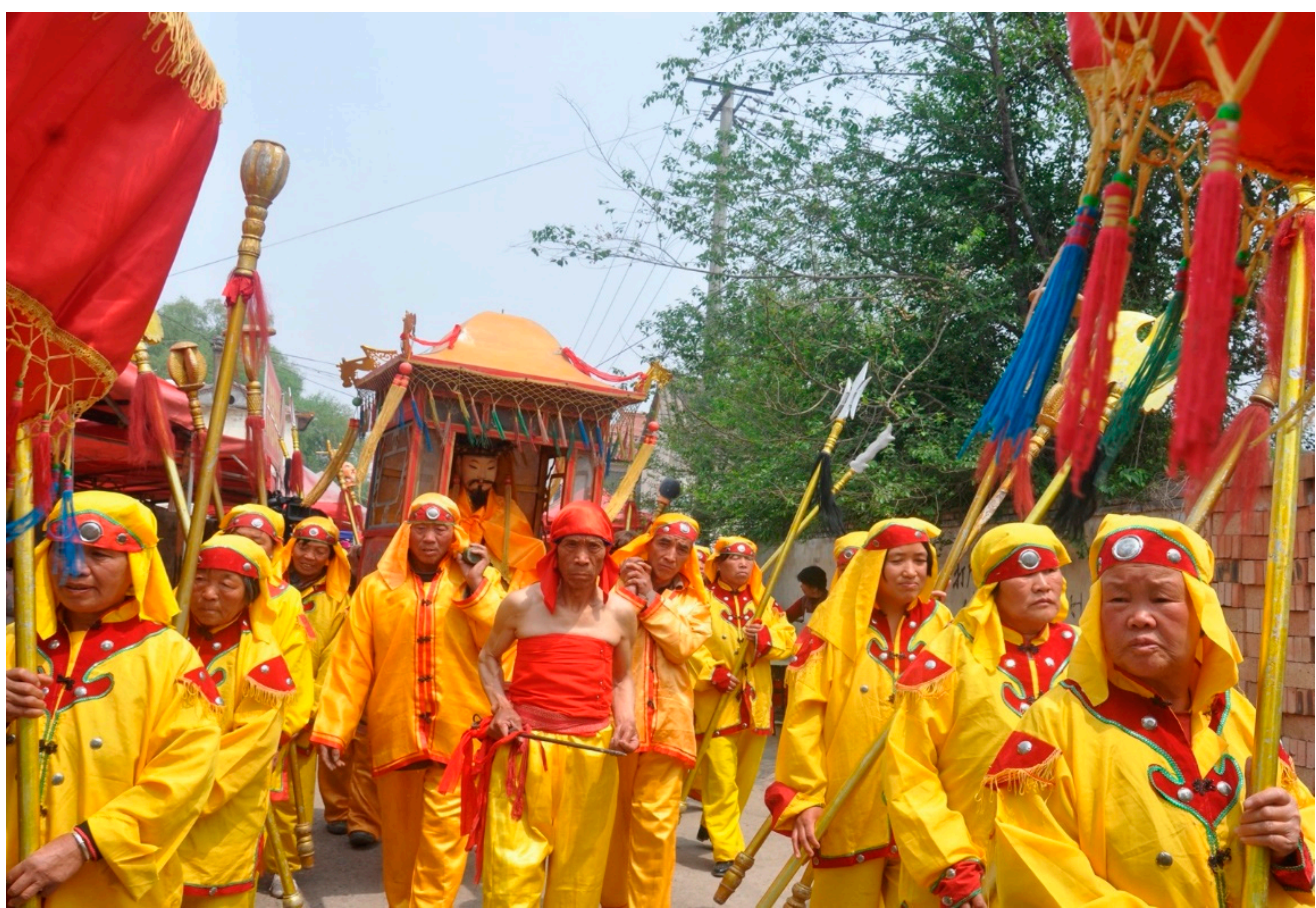

Figure 37. Jade Emperor Is Carried Out in His Sedan Chair. 


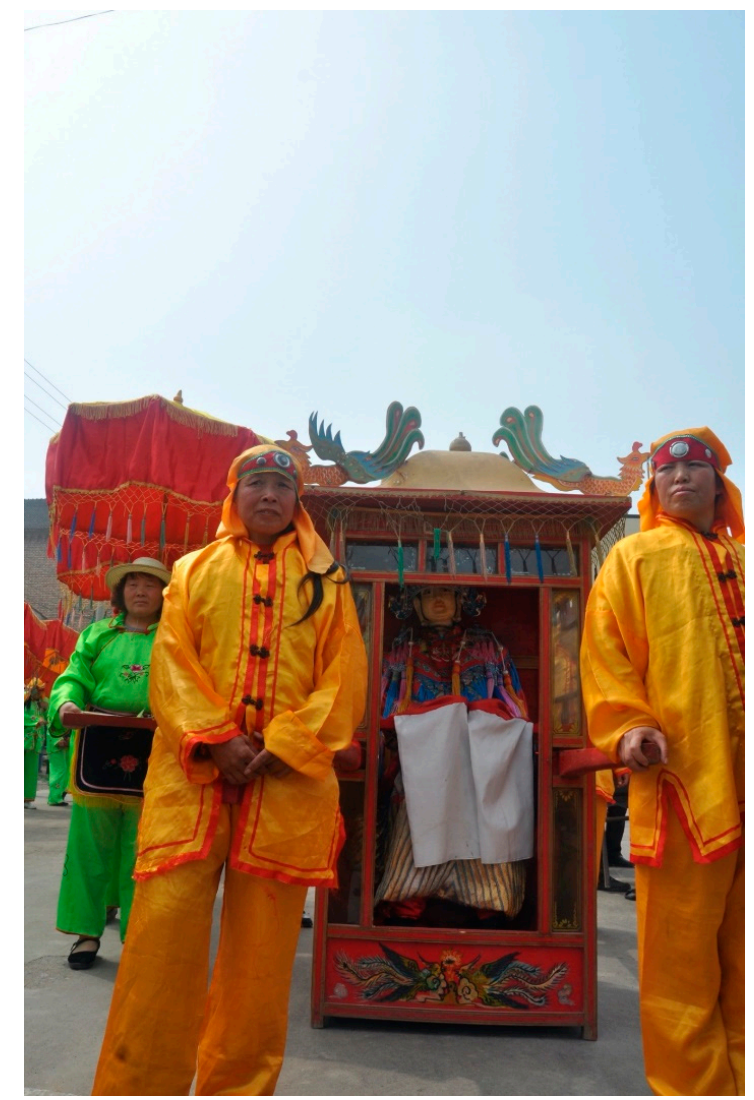

Figure 38. The Goddess Sits in Her Sedan Chair, Waiting for the Jade Emperor.

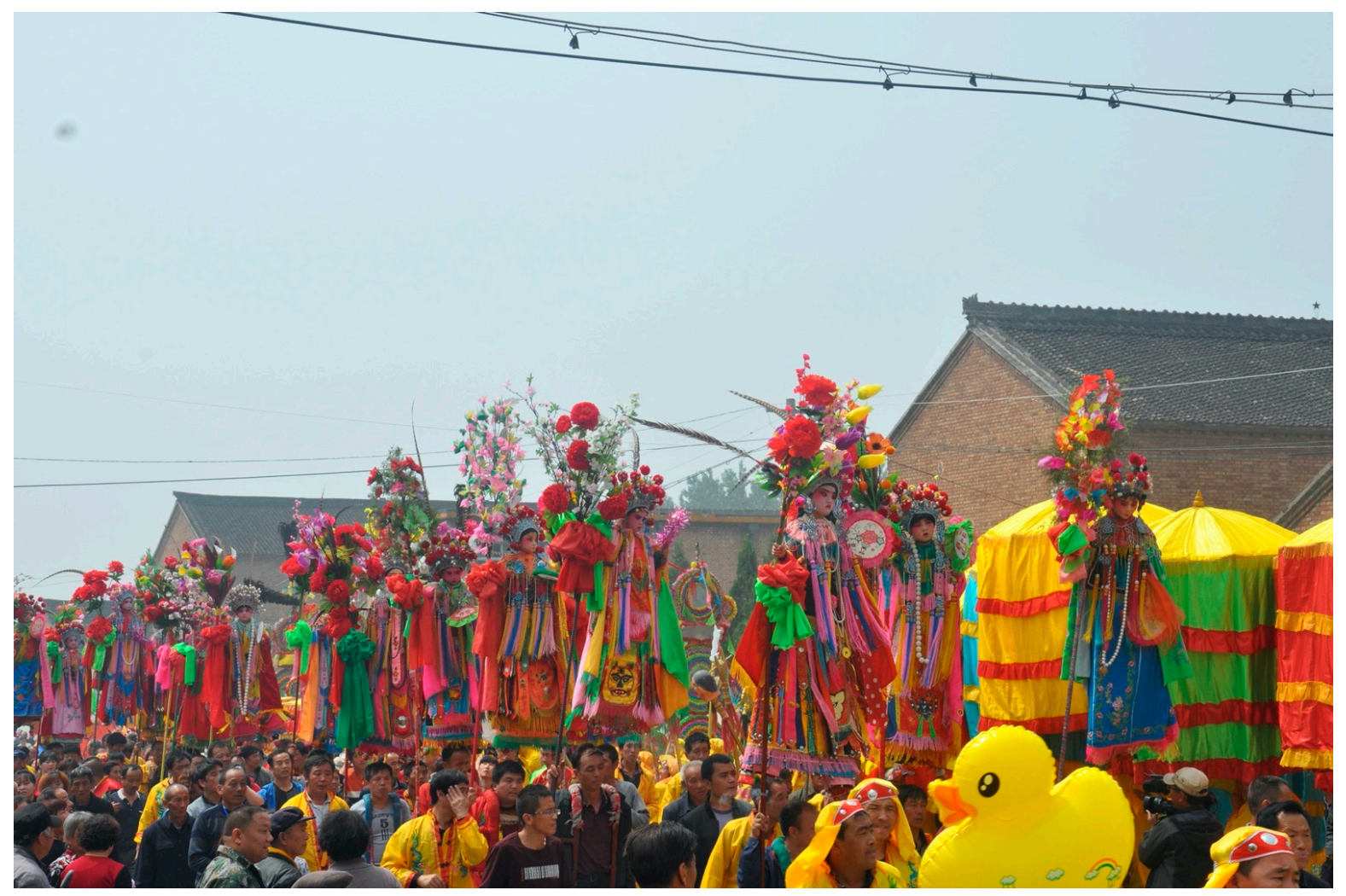

Figure 39. Crowds Follow the Procession to the Divine Arena. 
While the goddess was paraded alongside other deities in the pantheon of Jiacun, a grand show was put on with gongs, drums and pipes of colourful fans and banners; ceremonial parasols, placards and pennants; mule-drawn drum carts and flower carts; royal crosspieces (huanggang 皇䫅); tableaux (gushi 故事); ${ }^{44}$ and divine mansions, divine carriages and divine horses that were residences, conveyances and mounts for the invited gods and goddesses. There was also stilt-walking, masked parade (mianju dui 面具隊), dragon dance, lion dance, land-boat dance, rice-sprout dance (yangge 种歌), waist-drum (yaog $u$ 腰鼓) dance, etc.

Most spectacular of the street performances was the carrying of royal crosspieces (tai huanggang 抬皇梖) and the carrying of floats on poles (taige 抬閣). Also known as 'flower crosspieces' (huagang 花槙), the royal crosspiece is a pagoda-like majestic golden timber structure consisting in its lower part of a colourfully embellished heavy square wooden box with a long crosspiece placed across it; in its middle is a latticework embellished with brightly coloured ribbons and embroidered balls and wreaths with an oversized mirror fixed at the centre and in its upper part is an antenna-like top decorated with a feather duster (Figure 40). The crosspiece is made of flexible wood to allow easy swaying when carried along, hence the alternative name of the royal crosspiece as the 'swaying crosspiece' (huanggang 晃䫅).

The carrying of a float on poles, also known as 'carrying cosmetics on poles' (kangzhang 扛妝) and 'walking stories' (zou gushi 走故事) in Shangdang, is a popular form of shehuo performance, in which a young child, costumed as a famous figure from popular plays, stood on a small platform carried along by a man on two vertical iron poles (Figures 41 and 42).

The procession moved slowly down the avenue from the Pavilion of Guanyin at the crossroads to the Divine Arena at the southern edge of the village. Covering an area of approximately five thousand square metres, the Divine Arena was a public square that featured some recreation and sporting facilities including basketball courts and playgrounds for children. Following the procession all the way, huge crowds of people swarmed into the square (Figure 43). Some of those who lived around the square kindly left their houses open to let in people-whether known or unknown - for a view of the Assembling of the Deities from their balconies, windows and rooftops (Figure 44).

Under the direction of Du Tonghai, the Chief Master of Ceremonials, the divine images, mansions, carriages and horses were lined up in orderly rows. In front of a temporary altar set up at the centre of the Divine Arena stood two sedan chairs, one for the Primordial Sovereign and the other for the Jade Emperor, with the four Divine Carriages for the Dragon Kings of the Four Seas neatly arrayed behind them (Figure 45). The ritual of 'Assembling All the Deities' started off with three shots of ritual muskets. The Chief Master of Ceremonials walked up to the two golden chairs and knelt down, chanting the 'Writ of Assembling All the Deities' (Yuanshen wen 圆神文), which was followed by qupo 曲破 ${ }^{45}$ performed by the Entertainers. 


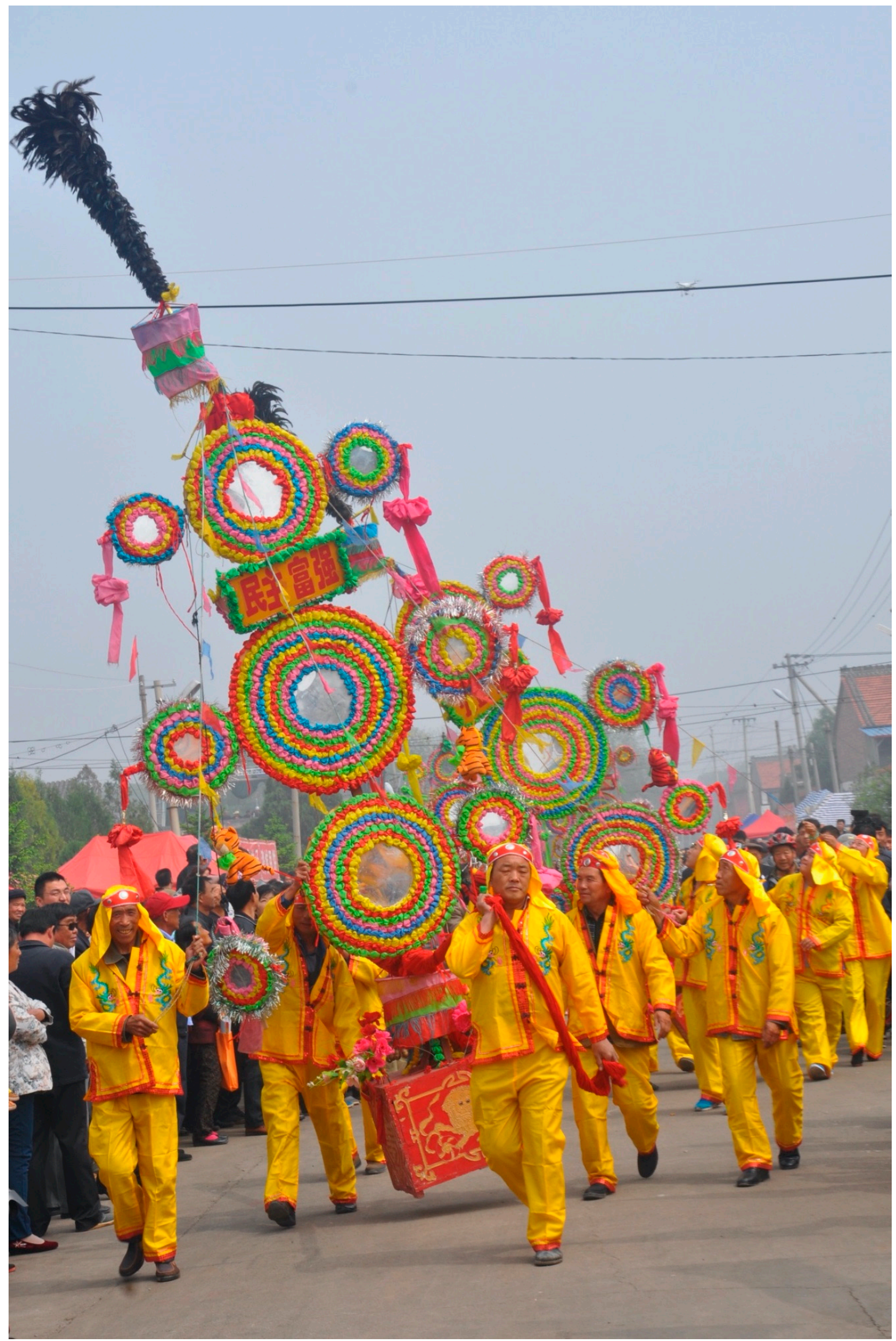

Figure 40. Carrying the Royal Crosspiece in Procession. 


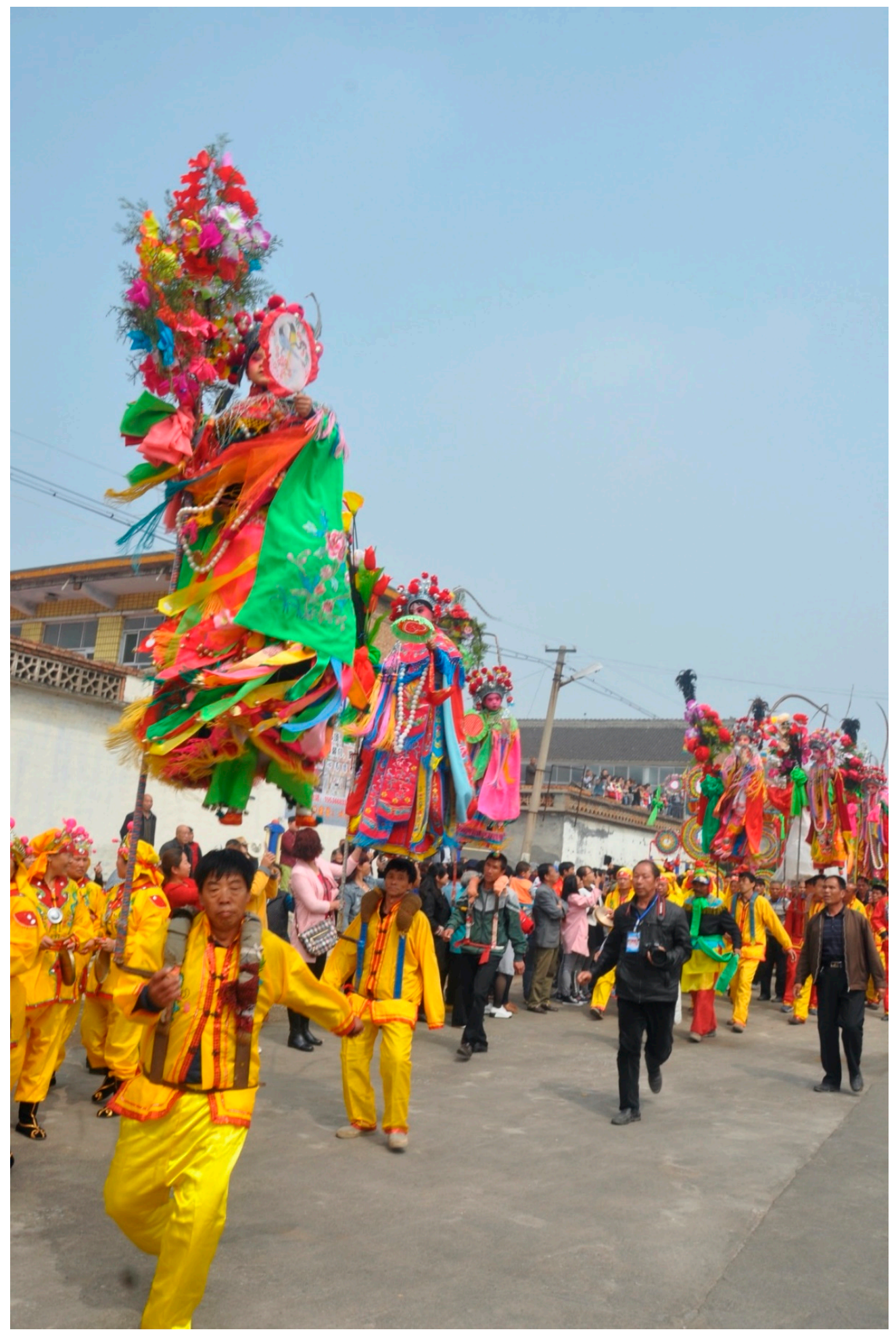

Figure 41. Walking Stories in Procession. 


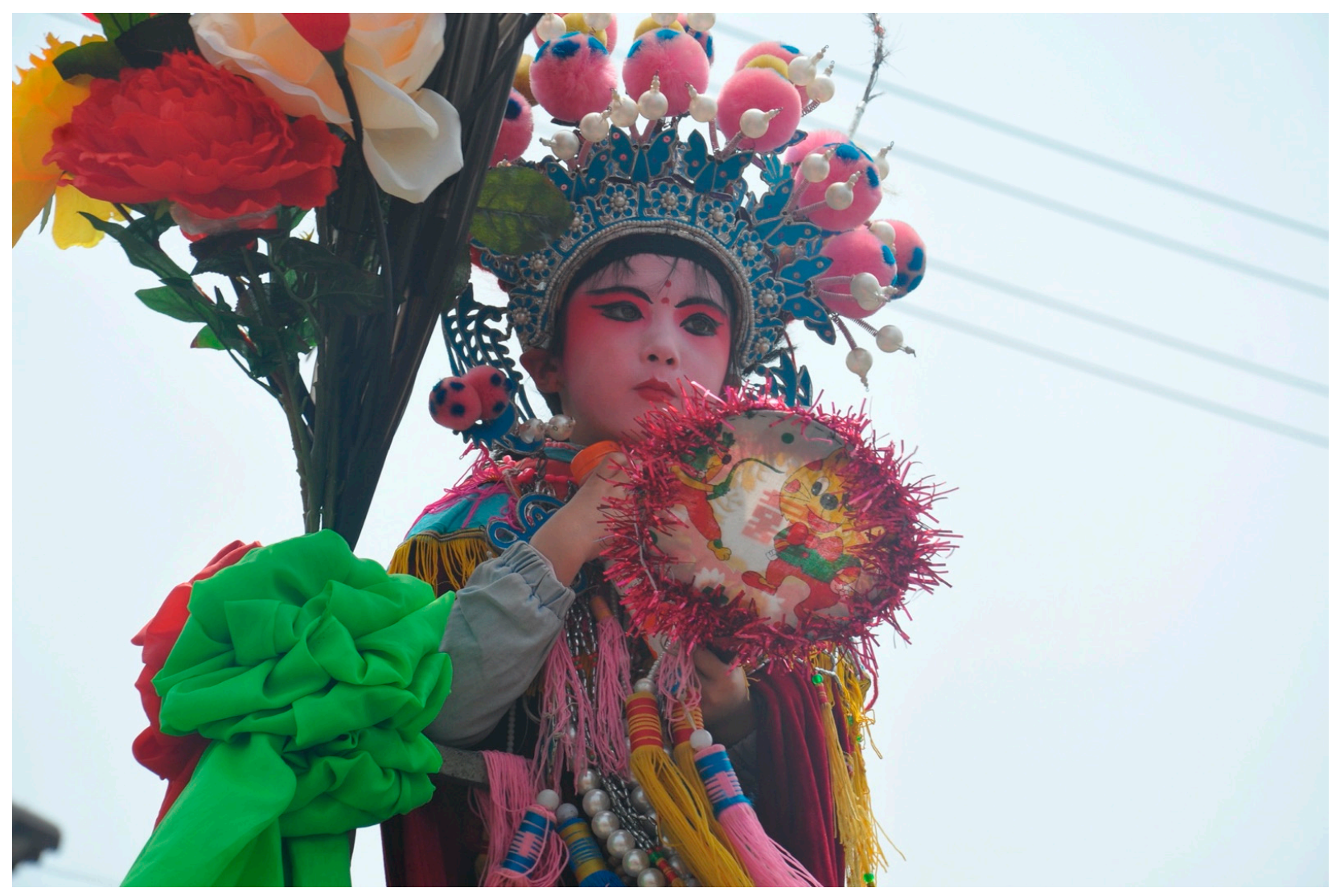

Figure 42. A Girl Dressed Up as Xiqu Character in Walking Stories.

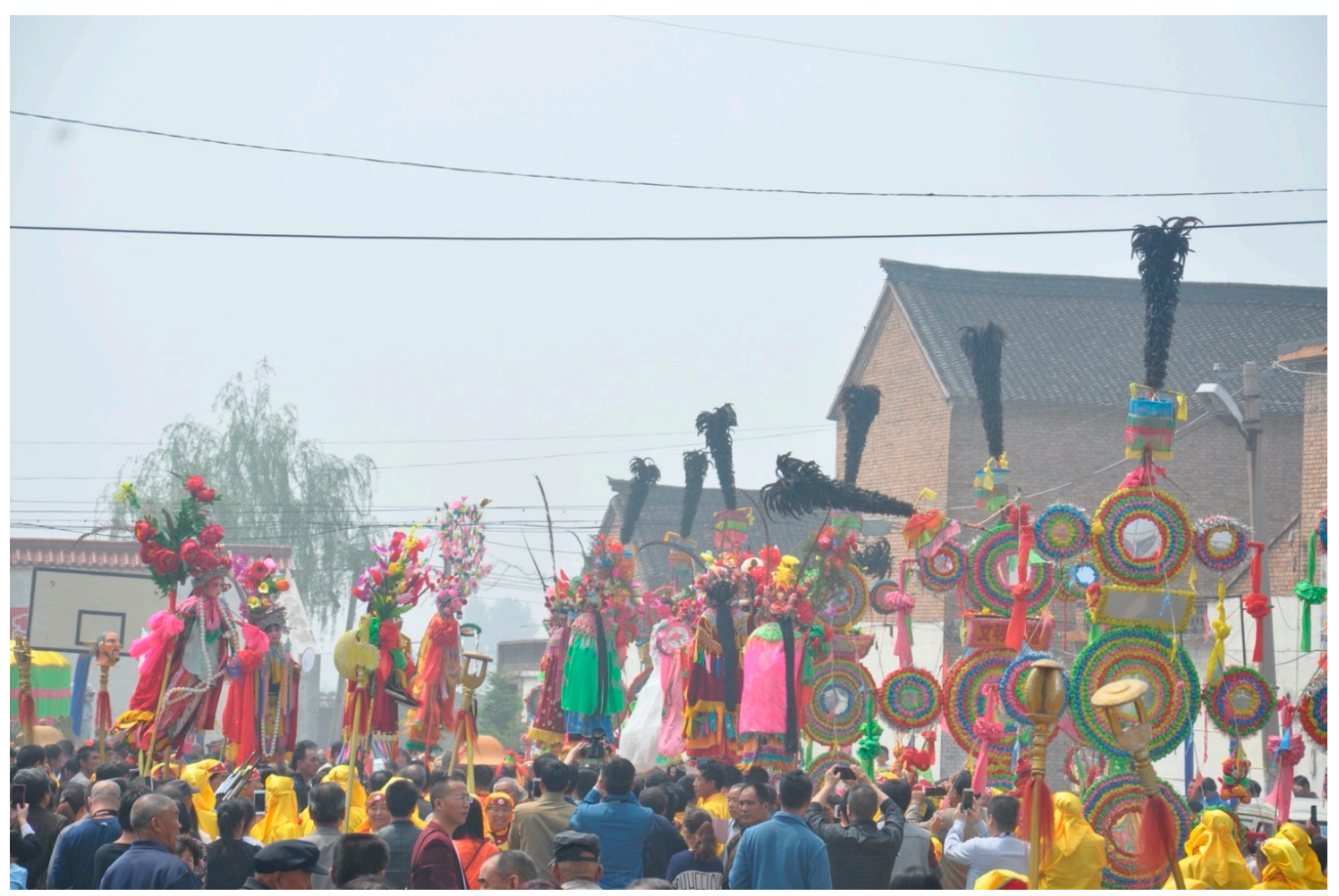

Figure 43. Crowded Divine Arena. 


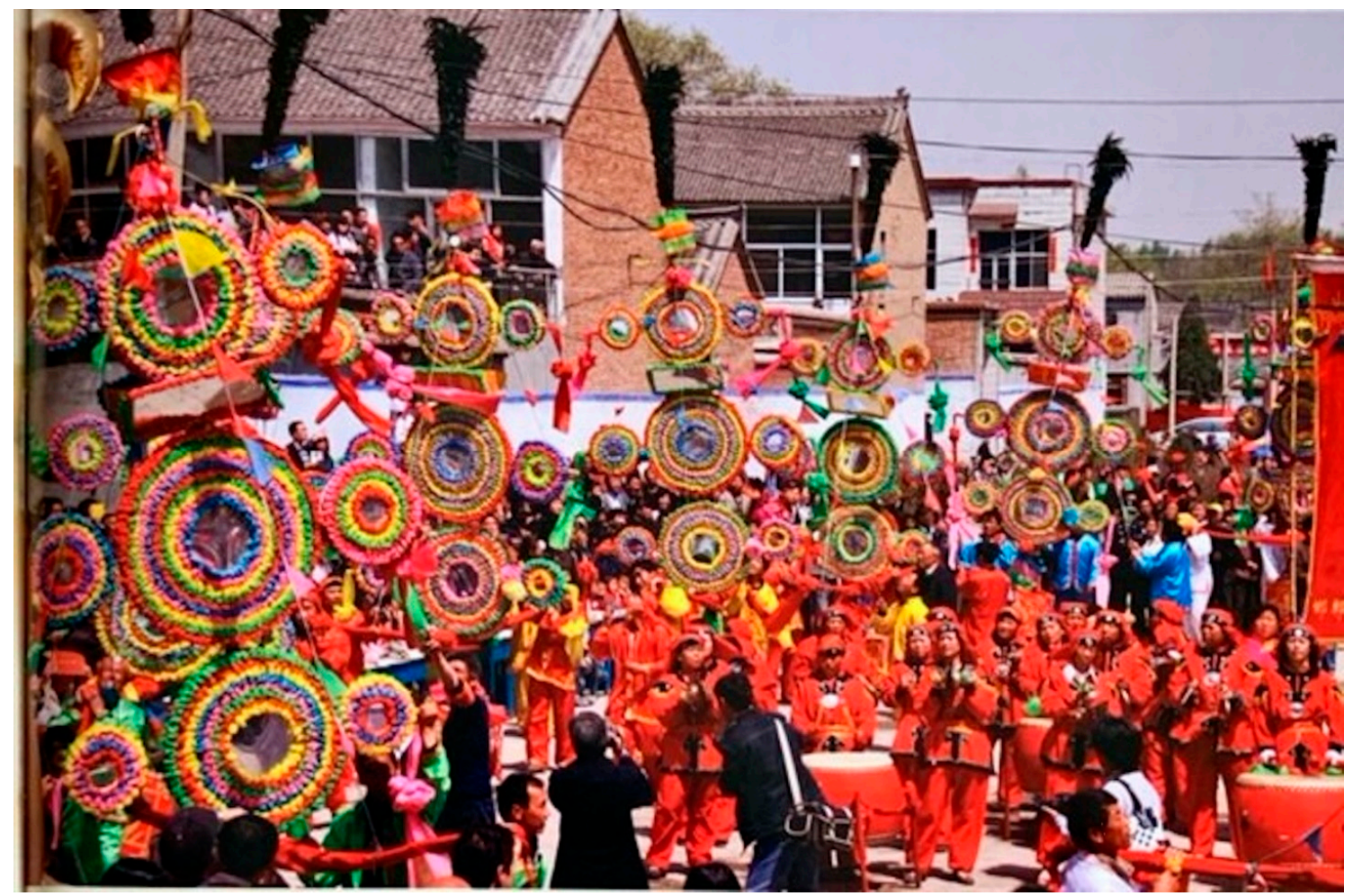

Figure 44. Watching Parade from Balconies.

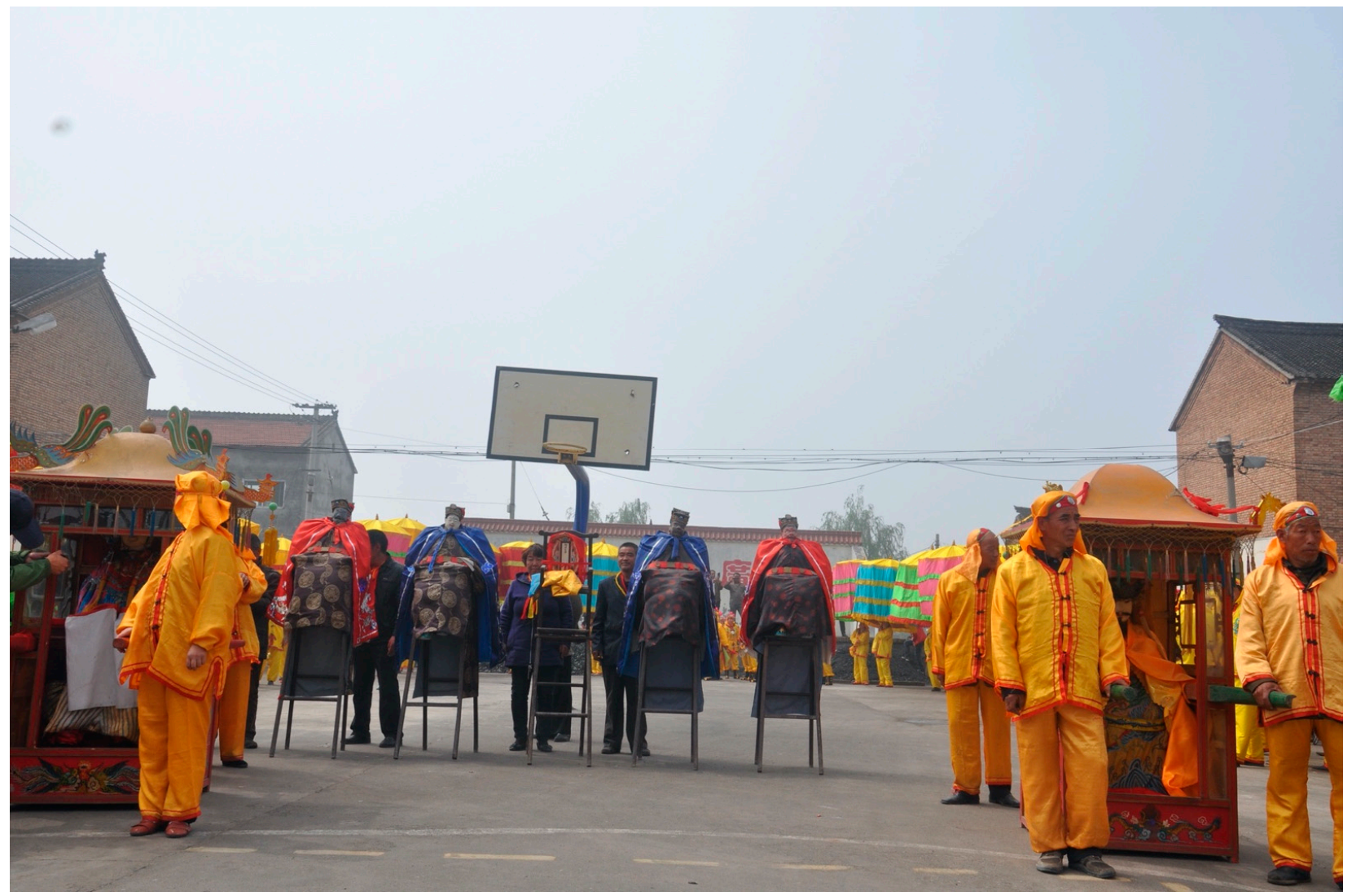

Figure 45. Assembling the Deities in the Divine Arena. 
Next came the ritual of 'Dismounting the Horses', which started with the Chief Community Head reciting the 'Writ of [Requesting the Deities to] Dismount Horses' (Xiama wen 下馬文). While he was reciting the text, divine images, carriages, mansions and horses were carried, doing a route around the altar called 'Circling the Arena' (yuanchang 圆 場). The carriers of divine images, carriages and spirit tablets would stop to bow to the Primordial Sovereign and the Jade Emperor seated in their sedan chairs, which was understood by all present as a sign of the god or goddess they carried dismounting from their horse to pay homage to the two paramount deities of Jiacun.

What followed was Crossing Five Passes and Decapitating Six Generals performed by the Entertainers in the local style of group skit (duixi). This play is about Lord Guan escorting Lady Gan and Lady Mi in search of their husband Liu Bei 劉備—a famous Three-Kingdom story that finds expression in almost all genres of traditional Chinese performance literature and performing arts. Like Emperor Guan (Guandi 關帝), Lord Guan (Guangong 關公) was a posthumous title conferred on Guan Yu 關羽 (?-AD 220). A native of Hedong 河東 in present-day southern Shanxi, Guan Yu was a powerful military general under Liu Bei (AD 161-223) the founder of the Kingdom of Shu 蜀 during the Three Kingdoms Period (220-280). He was deified after death and has since been widely worshipped as a god of war, a god of wealth, a rain-maker and a divine protector against demons, devils, diseases and bandits. ${ }^{46}$ The Lord Guan play (Guangong $x i$ 關公戲) consists of a series of highlight scenes enacting Lord Guan 'Hanging Up the Seal and Packing Up the Silver' (Guayin fengjin 掛印封金), 'Bidding Farewell to Cao Cao' (Guangong ci Cao 關公辭曹), 'Crossing Through Five Passes and Decapitating Six Generals', 'Travelling One Thousand Li Alone on Horseback' (Qianli zou danji 千里走單騎), 'Searching for [Liu Bei, His Sworn] Elder Brother for One Thousand Li (Qianli xunxiong 千里尋兄), 'Meeting [Zhang Fei 張飛, His Sworn Younger Brother] at Old City' (Gucheng hui 古城會) and 'Decapitating Cai Yang' (Zhan Cai Yang 斬蔡陽). Best known for its martial arts combat scenes, Crossing Five Passes and Decapitating Six Generals ranks among the most popular plays to stage and makes up the central core of Three-Kingdom plays (Sanguo xi 三國戲) in xiqu.

This play is listed in the Lijie chuanbu in the category of main group skit (zheng duixi), and as such, it is meant for stage performance after offering the seventh cup (Du 2011b, pp. 250, 253, 257). Clearly, its performance in the Divine Arena after the ritual of 'Circling the Arena' was not held as specified in the liturgical manual. It was not performed on stage in the temple, nor was there any area designated for its performance in the public square. Actors simply performed on the level ground, moving from one place to another as the story unfolded, thus turning the whole square into a huge open-air theatre. Spectators followed them, closely watching. Among them were some young children play-fighting at their heels, setting off a ripple of laughter and applause from time to time across the square. Lord Guan figured prominently as the central character in the play. Riding his Red-Hare Horse (Chutuma 赤兔馬) and wielding his Azure-Dragon Sword (Qinglongdao 青龍刀) and followed by ten or more armed foot soldiers escorting Lady Gan and Lady Mi seated in their sedan chairs, Lord Guan fought all along until he arrived at Old City, where he met his long-lost sworn brother Zhang Fei, hence a grand reunion (da tuanyuan 大團圆)-a happy ending typical of xiqu.

The Shangdang group skit manifests itself as a form of verse drama known as shizan 詩 灒, albeit still at a fairly rudimentary level on the whole. Composed in alternating segments of prose and verse using plain, colloquial language, the Shangdang group skit displays some affinity with Tang transformation texts (bianwen 變文) and Song-Yuan precious scrolls (baojuan 寶卷). Although its verse section contains occasional decasyllabic lines, the predominant form is pentasyllabic and heptasyllabic, with rhyme occurring on the last syllable in even-numbered lines, as in the verse section of transformation texts and precious scrolls. This is also the case with the sung parts of the beat-based form (banqiang $t i$ 板腔體) of xiqu, such as Jingju 京劇 or Beijing Opera and Clapper Opera (bangzi 梆子), including Shangdang Clapper Opera (Shangdang bangzi 上黨梆子). 
The Shangdang group skit specialises in historical drama and martial drama, particularly Three-Kingdom plays. Its performance is not confined to a fixed stage or space, which is a distinctive feature of folk temple theatre. Actors may play on the stage or on the street and may even play while riding horses, brandishing weapons or carrying sedan chairs along the street if need be. They perform primarily through speech and action, and singing is secondary and occasional. They speak in prose, but when it comes to the verse part, they intone (nian 念) or recite and chant (yinsong 吟誦). Intonation and recitation are thus the dominant mode of delivery. No string or wind instruments are played but percussion instruments such as drums, gongs and cymbals. When actors finish reciting one verse line, there will be two beats of gongs and drums altogether; when they finish reciting four verse lines, they will perform an action to the rhythmic beat of gongs and drums. Speech in prose is usually delivered without any instrumental accompaniment.

The Shangdang group skit arguably retains features and functions of a Song dynasty court group skit and group dance (duiwu 隊舞). Derived from Tang dynasty court group dance and dance skit (wuxi 舞戲) (Jiaofang ji 1.11-12; Gongci 1.11b; Yuefu zalu 1.42, 1.45), the Song court group skit was a major form of the royal command performance alongside group dance and sketch comedy (zaju 雜劇) presented to accompany the ritual of offering cups (Dongjing menhua lu 9.832-835; Wenxian tongkao 146.12a-12b, 14b-15a). The Song court group dance skit featured a court music officer called 'Adjutant' (canjun 曑軍), ${ }^{47}$ who is also referred to in Song dynasty sources as Master Bamboo Staff (zhuganzi) because he held a bamboo staff or bamboo-staff whisk (zhugan fuzi 竹竿拂子) when directing court performances (Maofeng zhenyin manlu 48.3b-10a; Dongjing Menghua lu 9.833).

The group skit and the bamboo staff as described in the Song sources appear still extant - though not in their entirety or originality - in Shangdang temple festivals. While there is no evidence of a direct link between Song court theatre and Shangdang folk temple theatre, historical records are abundant, with a considerable number of Song court musicians and entertainers breaking free of their Jurchen escorts and escaping into mountains in Hedong and Shangdang after being taken across the Yellow River at Gongxian 鞏縣 in the wake of the Humiliation of Jingkang (Jingkang zhi chi 靖康之恥)一the fall in early 1127 of Bianliang 汒梁, the capital of the Northern Song dynasty to the Jurchens, who ransacked Bianliang, capturing both Emperor Qinzong 欽宗 (r. 1126-1127) and his father, Emperor Huizong 微宗 (1100-1126), and escorting them along with hundreds of members of imperial and aristocratic families and thousands of court officials, attendants, artists, artisans and entertainers via Shanxi to Shangjing 上京 ${ }^{48}$ (Sanchao beimeng huibian 77.12b16a, 78.3b-5b; Jingkang baishi 6.201, 7.223-224; Songshi 23.436, 129.3027; Jinshi 28.691, 39.882; and Nanzheng luhui, cited in Jingkang baishi 4.173-174). Some of those who had successfully escaped the clutches of Jurchen soldiers settled down in the Shangdang area. They drew on their performance skills and first-hand knowledge of court rituals, performances and celebrations, making a living as ritualists, musicians and entertainers-hence the reason traces still remain in Shangdang temple festivals of ritual and theatrical performances from the Song and Jin eras (Yang 1997a). Thus, it would not seem to be far-fetched or fanciful to think of the Shangdang group skit as a surviving remnant of the Song court theatre.

With the grand reunition of Lord Guan and Zhang Fei at Old City, the morning session of the Initial Sai came to an end. Minutes later, all participants gathered up behind the ritual leaders and marched in procession from the Divine Arena to the Bixia Temple. Between the morning session and afternoon session, there was a two-hour lunch break. I was invited to have lunch with Du Tonghai in his home. Among his guests was Li Tiansheng, a renowned local scholar on Shangdang temple festival and temple theatre. I had a very fruitful conversation with them at the table.

\subsection{The Initial Sai: Afternoon Session}

Among the major rituals scheduled to be performed in the afternoon session were 'Receiving the Palanquins' (jiejia 接駕), 'Settling the Deities' (anshen 安神), 'Offering Three Cups' (gong sanzhan 供三盈) and 'Leading the Sheep' (lingyang 領羊), all of which were 
held in the front courtyard of the Bixia Temple. Also called 'Receiving the Deities' (jieshen 接神), the ritual of 'Receiving the Palanquins' started with the Chief Master of Ceremonials reciting the 'Writ of Receiving the Deities' (Jieshen wen 接神文). All ritual participants knelt on the floor while he was reciting the text until he finished the last word, with which ended the ritual of 'Receiving the Deities' (Figure 46). He instructed Wei Qianxiu, the Master of Ceremonials, to offer incense on behalf of the ritual community to all invited gods and goddesses (Figure 47) and an ensemble of ten musicians from the Assembly of Eight Sounds to accompany him 'bowing in worship four times and offering burning incense three times' (sanxian sibai 三獻四拜).

He then recited the 'Writ of Settling the Deities' (Anshen wen 安神文), and after that, he issued an instruction for all the deities to be carried in their sedan chairs, carriages and spirit tablets to their proper places, each according to their rank and status in the pantheon of Jiacun, headed by the Jade Emperor and the Primordial Sovereign (Figures 48 and 49).

Now that the deities were settled, it was time to 'Offer Three Cups'. The first offering was a cup of wine, the second of food and fruit and the third of tea. The ritual of 'Offering Three Cups' was performed by Tray Carriers (tingzi) and Canopy-Holders (weizi), who were all beautifully dressed women from the age of twenty to sixty as they appeared. They lined up in two lines near the entrance hall under the guidance of Master Bamboo Staff, Song Huaizhi. The Tray Carriers each held a flower in their mouth to show piety for the deities while carrying a tray with cups on it to a long offering table positioned against the wall of the main hall (Figure 50). When they reached the table, they carefully placed the offerings before spirit tablets and filed out back to the entrance hall to fetch another cup of offerings (Figure 51). Each cup was offered twice, six times in total.

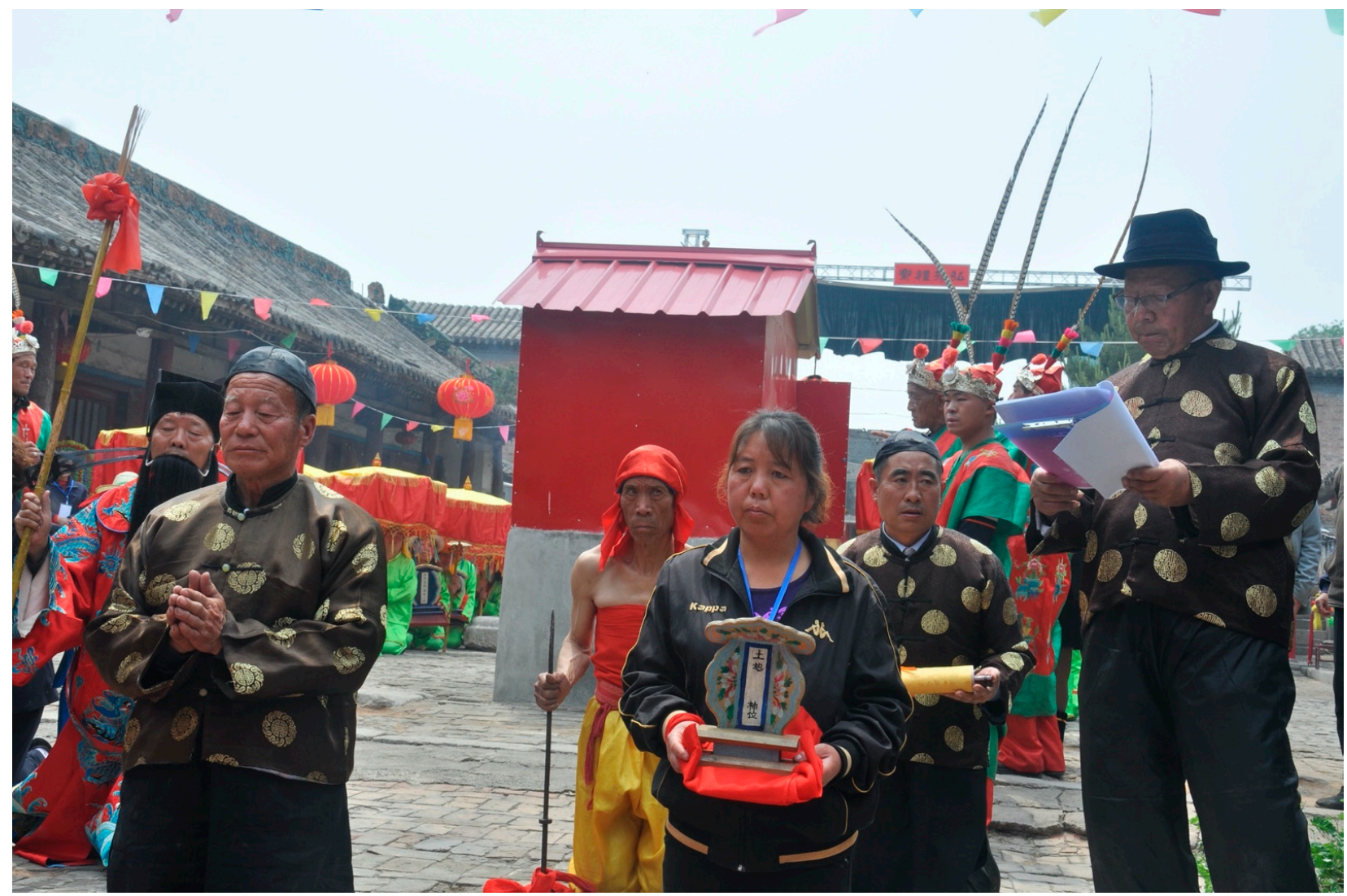

Figure 46. Du Tonghai, the Chief Master of Ceremonials, Reads the 'Writ of Receiving the Deities'. 


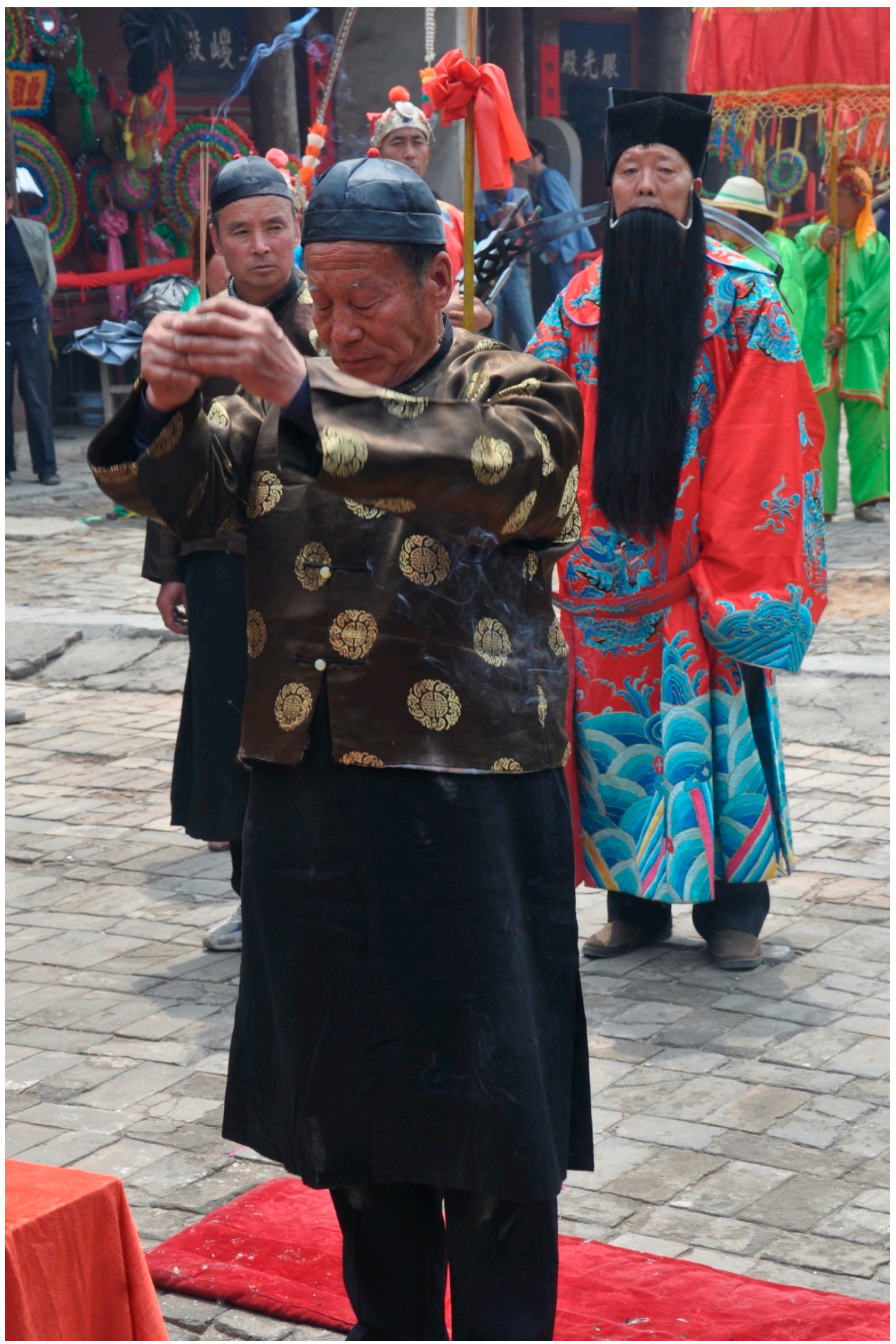

Figure 47. Wei Qianxiu, the Master of Ceremonials, Offers Incense. 


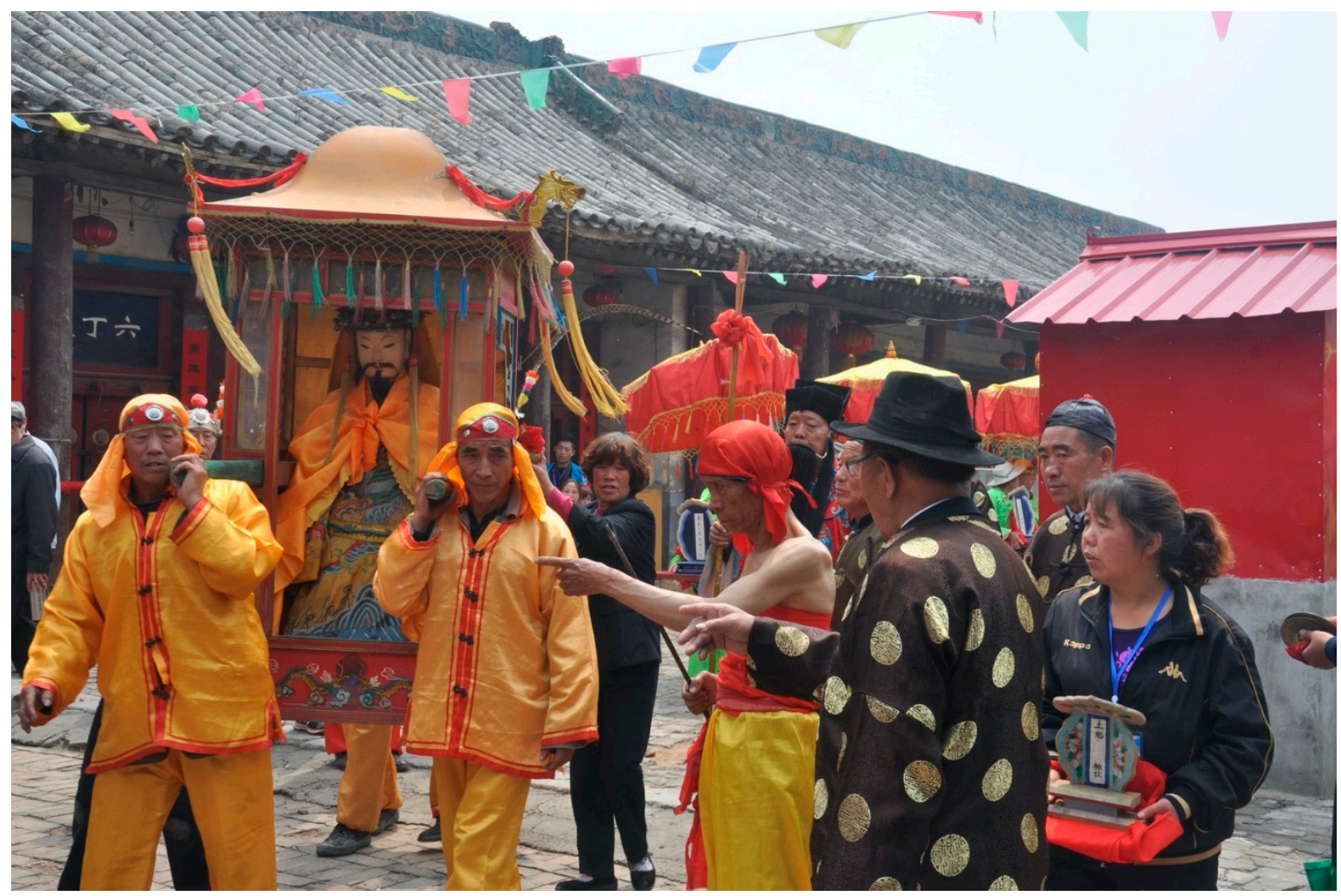

Figure 48. Jade Emperor Is Carried into Bixia Temple and Settled in Front of the Incense Pavilion.

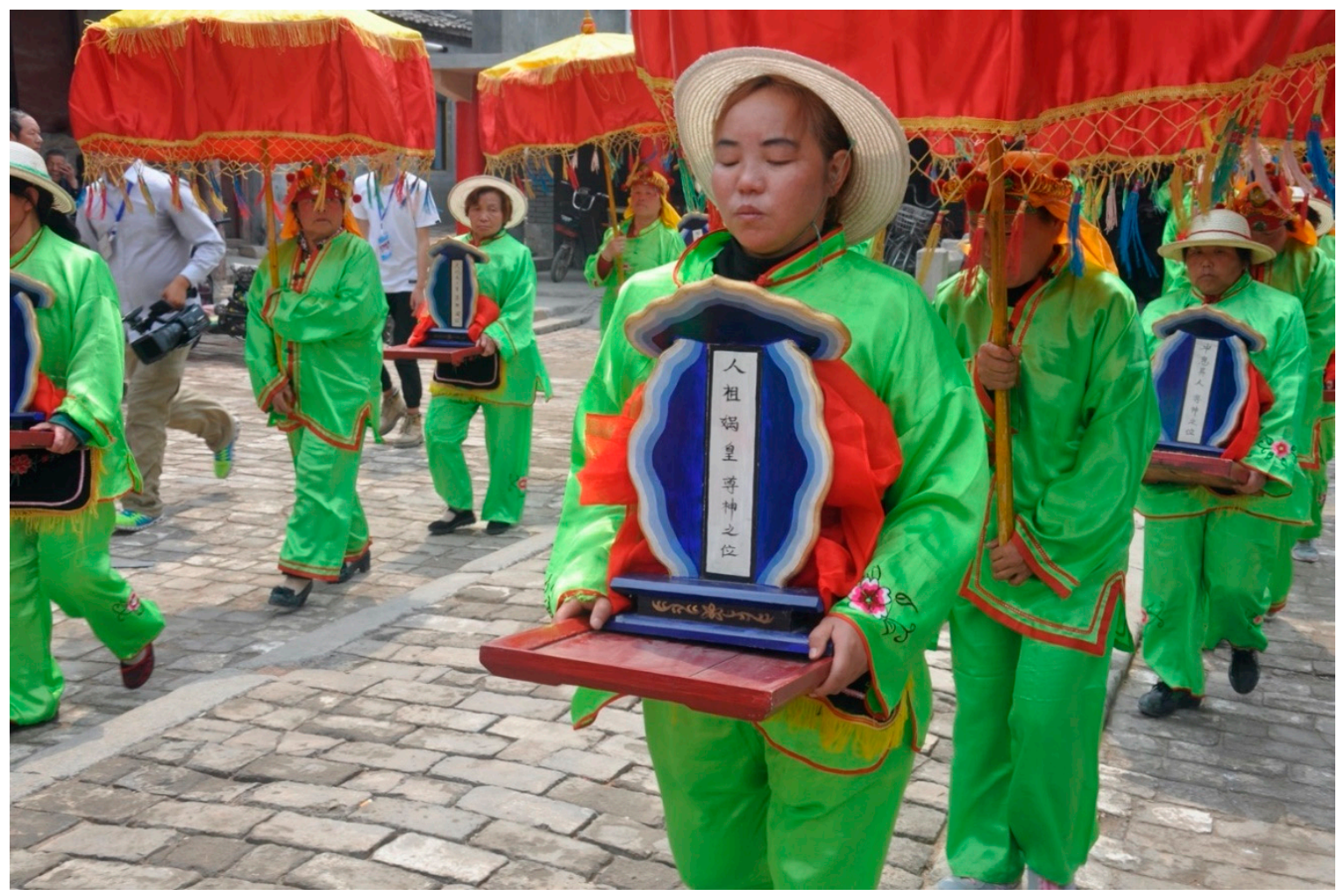

Figure 49. Spirit Tablets Are Carried and Settled in the Bixia Temple. 


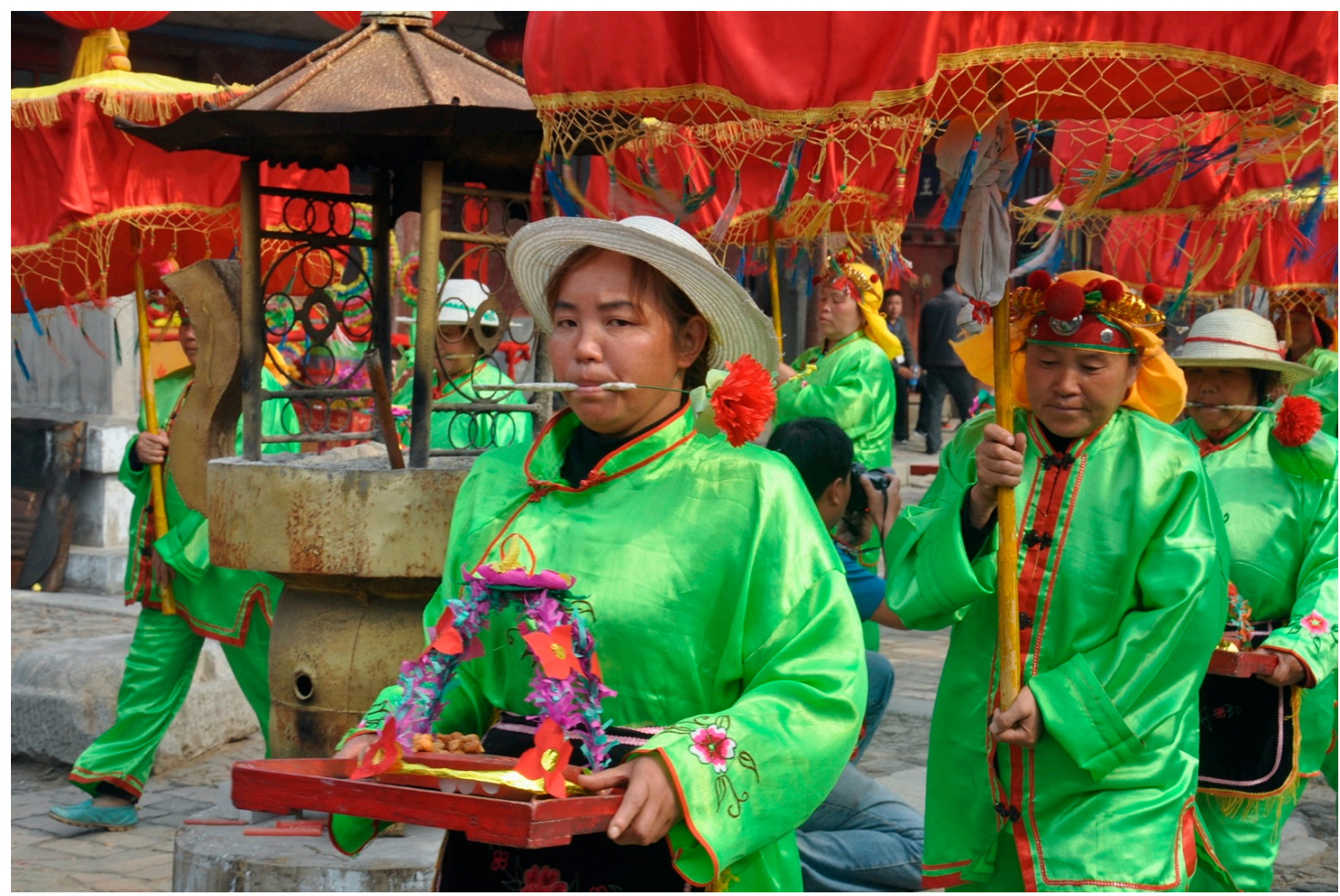

Figure 50. Tray Carriers Hold Flowers in Their Mouths While Carry Offering Trays.

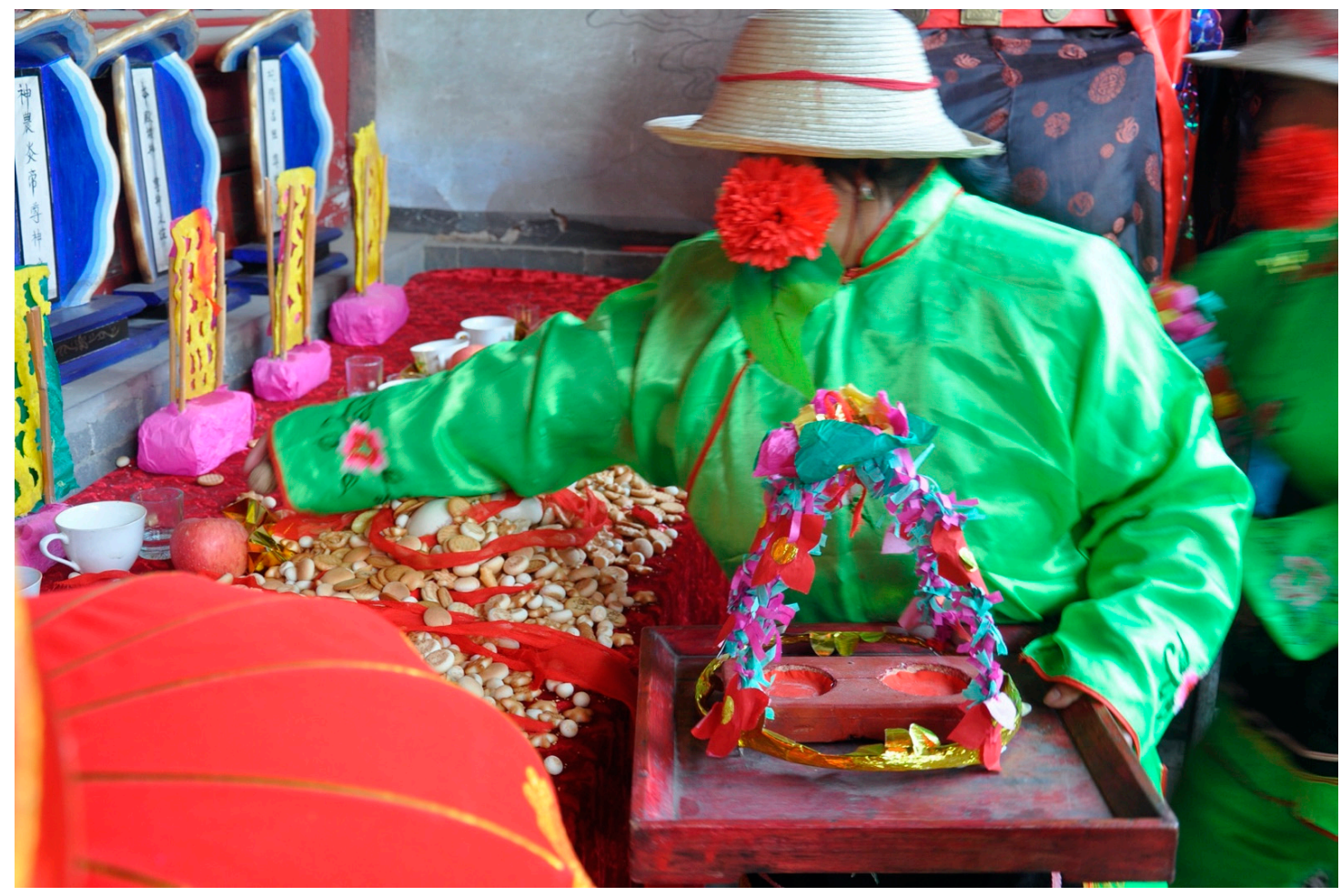

Figure 51. Tray Carriers Put Offerings before Spirit Tablets on the Offering Table.

Next came a sacrificial ritual called 'Leading the Sheep'. After a sheep was led in, Du Tonghai, the Chief Master of Ceremonials, recited the 'Writ of Leading the Sheep' (Lingyang wen 領羊文). Three cups of wine were then poured over the sheep to wash it clean by a ritual assistant, who then led the sheep out and handed it over to its owner. In the past, 
however, the ritual would involve a sheep being slaughtered on the scene as a sacrifice to the goddess (Du 2016).

Now it was time to entertain the deities with theatrical performance. People moved aside from the Incense Pavilion and gathered in front of the stage over the gateway to watch the Shangdang group skit, Decapitating Hua Xiong (Zhan Hua Xiong 斬華雄). Also known as Lord Guan Decapitates Hua Xiong While the Wine Is Still Warm (Guan Gong wenjiu zhan Huao Xiong 關公酒斬華雄), Zhan Hua Xiong is another Lord Guan play in the standard repertoire of the Shangdang group skit. In the play, Guan $\mathrm{Yu}$, who has not yet established his reputation as a formidable warrior, fights Hua Xiong, a seemingly invincible general under the warlord Dong Zhuo 董卓 (AD 132-192), and returns from the battlefield with Hua's head before a cup of warm wine cools off. Actors first played on the stage, but when it came to the chase scene, the dramatic show turned into a street performance. To escape Lord Guan's chase, Hua Xiong fled the stage, and Lord Guan intercepted and stopped him in the courtyard, forcing him to rush for the gate and run out of the temple to the main street. The drama ended with Hua Xiong running back to the temple to be caught and beheaded by Lord Guan onstage.

In the Lijie chuanbu, Decapitating Hua Xiong is listed as a 'group skit for offering cups' (gongzhan duixi) alongside another Three-Kingdom play, Fighting Lü Bu (Zhan Lü Bu 戰呂 布), for the interlude performance between the fifth and sixth cup (Han et al. 1987a, p. 87; Du 2011b, p. 257), but to my surprise I found this play presented as a main group skit (zheng duixi) immediately after the completion of the ritual of offering cups. I turned to Du Tonghai for an explanation and was told that the adjustments had been made on the advice of Li Tiansheng on the grounds that this play was perfectly suitable for both stage and street performance and that people just enjoyed the thrill of the chase (Du 2016).

Next came the stage performance of The Hall of the Earth God (Tudi tang 土地堂), a farce (yuanben) about sworn brothers gambling, cheating, drinking, quarrelling and fighting before reaching reconciliation at an Earth God Temple (Figure 52). This play is characterised by an exaggerated and ludicrous situation, physical humour, deliberate absurdity, bawdy jokes and pleasantly boisterous horseplay to entertain people and make them laugh, thus distinguishing itself from the main group skit that features historical figures and events as we have seen in Lord Guan plays. The Hall of the Earth God is one of the eight yuanben plays recorded in the Lijie chuanbu. Similar to the Shangdang group skit with its origins traceable to Song dynasty group dance and group skit, Shangdang yuanben is rooted in Song zaju and Jin yuanben (Huang 1987, pp. 146-49; Hu 1988, pp. 6-10). Hardly any texts of Jin yuanben have survived except for seven hundred-odd titles recorded by Tao Zongyi 陶 宗儀 (fl. 1348) under the 'Catalogue of Court Texts' (Yuanben minglu 院本名目) in Nancun's Notes upon Rest from the Plough (Nancun chuogeng lu 南村輟耕, 436-450). Jin yuanben had long been thought of as an early form of Chinese theatre that failed to survive beyond the Yuan dynasty until the discovery of the Lijie chuanbu. The staging of The Hall of the Earth God in Jiacun temple festivals provides valuable evidence for yuanben having survived and having continued to be performed into the modern era.

After the theatrical performance, all the male deities, including the Jade Emperor, were carried out of the Bixia gong to their own shrines and temples. This is because Bixia yuanjun is a maiden goddess, so no male deities or spirits from other temples or shrines are allowed to stay overnight in her temple. With the return of the gods to their home temples or shrines, the afternoon session of the initial sai came to an end. 


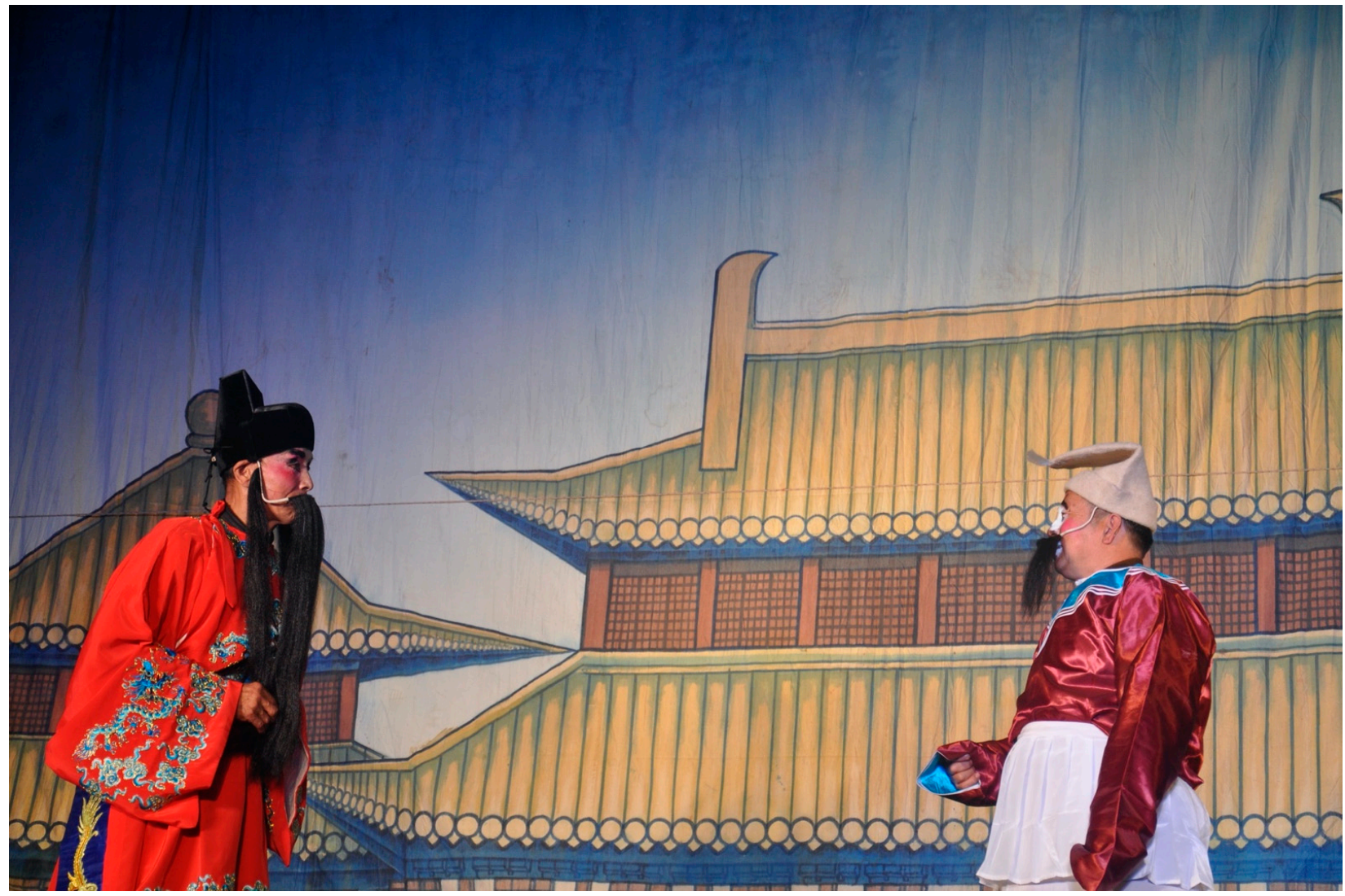

Figure 52. A Scene from The Hall of the Earth God.

\subsection{The Main Sai}

The main sai, which usually lasts the whole day in a small-sai year, was reduced to a half-day event scheduled for the morning of the fourth day of the fourth month (10 May), with the purpose of bringing down the cost and achieving maximum concentration (Du 2016).

The main sai began very early in the morning with a ritual called 'Golden Rooster Announces the Dawn' (Jinji baoxiao 金䌖報堯). At daybreak, a massive crowd of people assembled in the temple to listen to the Chief Master of Ceremonials reciting 'the Writ of Announcing the Dawn' (Baoxiao wen 報墝文), 'the Writ of Waking Up' (Cuiqin wen 催寢文), 'the Writ of Washing Up' (Guanshu wen 搵漱文) and 'the Writ of Offering Incense'. While he was reciting the writs outside in front of the Incense Pavilion, it was understood that Bixia yuanjun was washing up and dressing in her sleeping hall with the assistance of her maidservants (Figure 53).

The goddess was then carried out to receive offerings of cups, together with the Jade Emperor, who had already been carried over from his own temple. Following the ritual of offering cups, the Chief Community Head invited the other ritual leaders to walk up and kneel down before the Jade Emperor. All people present stood in awe listening to him reciting 'the Writ of Obeying Orders' (Tingming wen 聽命文).

Next came 'Offering Sacrifices to the Sun' (ji taiyang 祭太陽) and 'Offering Sacrifices to the Moon (ji taiyin 祭太陰), which started with the solemn performance by the Entertainers of 'Bells and Drums Sound Simultaneously' (Zhonggu qiming 鐘鼓齊鳴). To the bell and drum music, the Chief Community Head turned to the east and knelt down together with the other leaders of the sai festival, reciting loudly 'the Eulogy to the Sun' (Song taiyang 頌 太陽). After reciting the text, he took a cup of wine from a Wine Master, lifted it up and poured the wine in the direction of east as an offering to the sun, accompanied by diz $i$ 笛 子 flute music. This was done three times altogether. Then, he turned around to the west, 
facing the direction where the moon rises, reciting 'the Eulogy to the Moon' (Song taiyin 頌 太陰) and offering three cups of wine to the moon as he had done to the sun.

Embedded between the first and second cup was the performance of a group skit called Eight Immortals Celebrates the Birthday (Baxian qingshou 八仙慶壽), which began with the Leader of Entertainers reciting 'the Writ of Inviting the Star of Longevity' (Qingshou wen 請壽文) and ended with him reciting 'the Writ of Seeing off the Star of Longevity' (Songshou wen 送壽文). This was a short and simple masked performance in which the Eight Immortals were lined up to offer rhyming verse birthday wishes to the Star of Longevity (Figure 54).

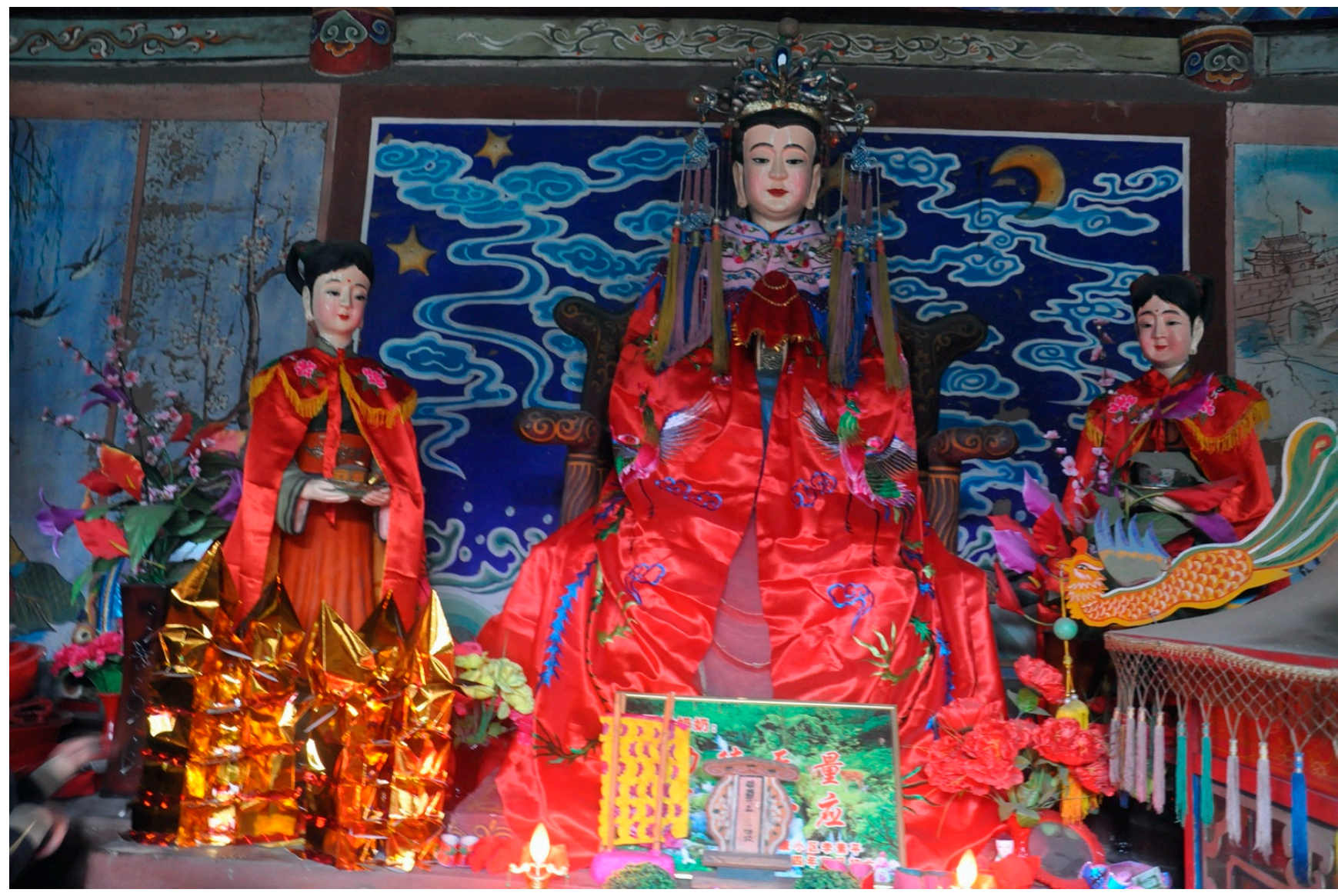

Figure 53. Bixia Yuanjun Flanked by Maidservants in Sleeping Hall.

The offering of the second cup was followed by another group skit called Dancing Jianzhai (Tiao Jianzhai 跳監齋). This muted masked performance featured Jianzhai 監齊 (Warden of Vegetarian Food), the god of the kitchen in Buddhist and Daoist temples and monasteries. The actor who played Jianzhai wore a mask with three heads and a costume with six arms. Accompanied by a group of masked minor deities, Jianzhai jumped and danced while holding a melee weapon in each hand. His exaggerated jumping dance and funny-looking costume and makeup aroused great interest from ritual participants and spectators (Figure 55). 


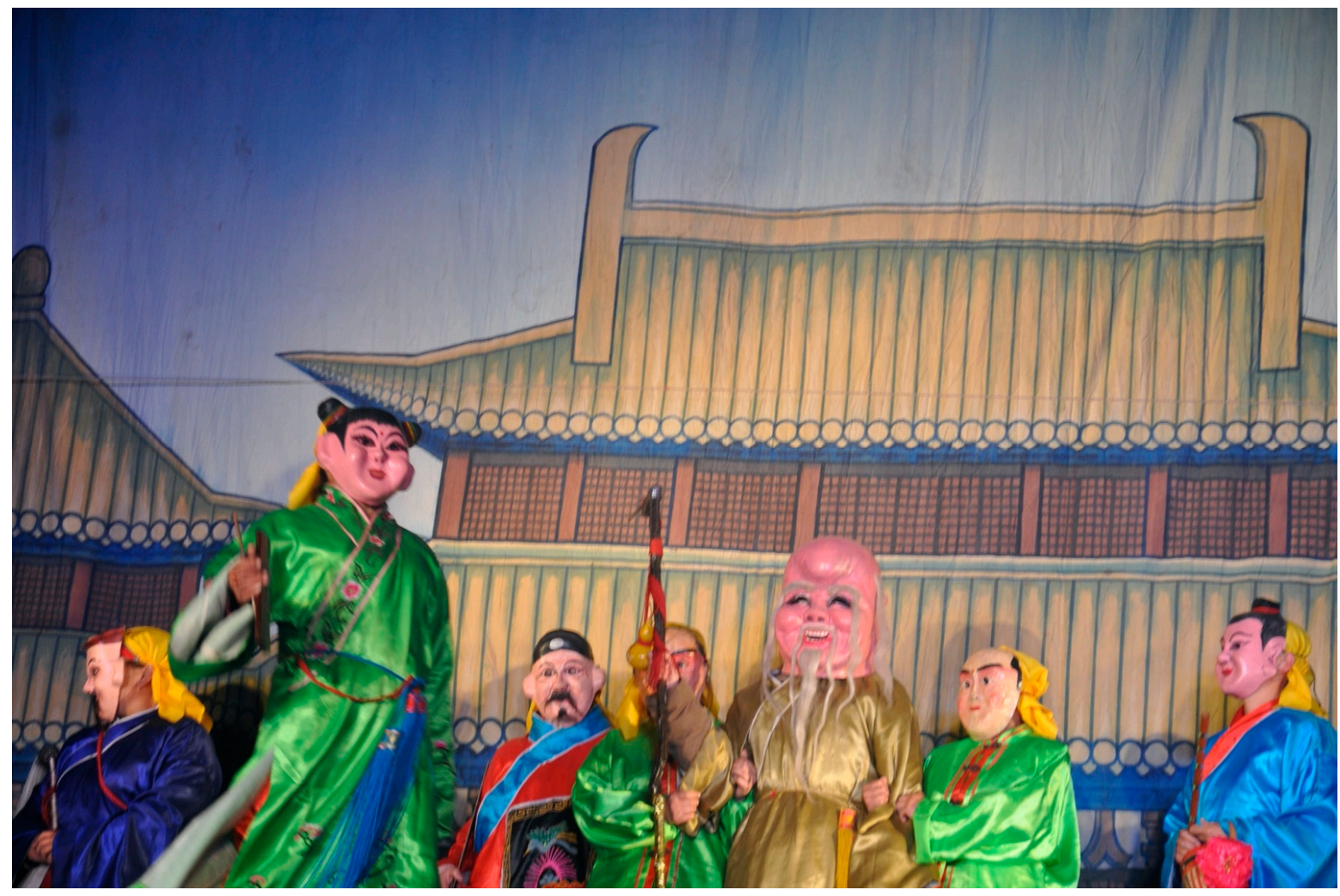

Figure 54. A Scene from Eight Immortals Celebrate the Birthday.

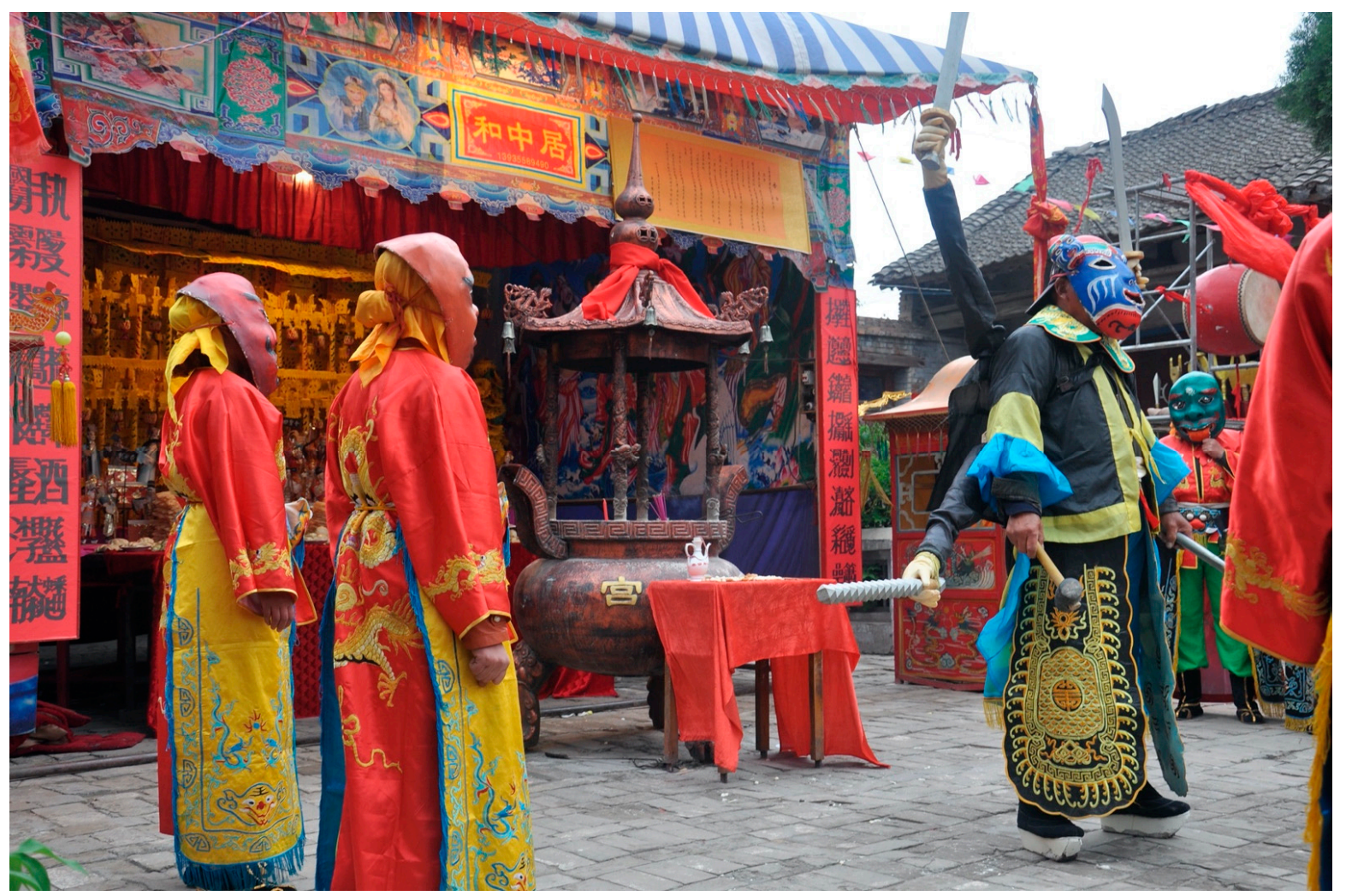

Figure 55. A Scene from Dancing Jianzhai. 
Presented after the third cup was A Monkey Extracted from Its Shell (Yuanhou tuoke 猿猴 脱殼), which is listed in the 1574 ritual manual as a group skit under the title of Yuanhou tuojia 猿猴脱甲 49 , to be enacted after the fifth cup in the mansion of 'Rooftop Represented by the Lunar Swallow' (Wei yueyan 危月燕) (Du 2011b, p. 256). However, in the Jisi wenfan, a ritual text copied by hand during the reign period of Daoguang 道光 (1820-1850), this play is designated for performance after the fifth cup in the mansion of 'Horn Represented by the Wood Dragon' (Han et al. 1991a, p. 35). ${ }^{50}$ This was a farcical mime featuring one actor performing silently through miming a monkey grooming, walking, running, drinking, eating, climbing, turning, stretching, bending, swinging and jumping until tiring himself out and lying down on a fine piece of brown felt. Then came along two carriers of food plates (tingzi), who poured through a mesh sieve a bag of flour on the head, body and limbs of the actor who impersonated the monkey before carrying him away, thus leaving the contours of a monkey on the felt. They then picked up the felt carefully from the ground and hung it beside the Incense Pavilion. In Shangdang, this play is frequently performed as a nuo-exorcism rite during a funeral service, and the felt bearing the shape of the monkey will be hung in a mourning hall as a talisman or fetish to ward off evil spirits (Du 2016).

\subsection{The Final Sai}

The final sai started after a lunch break with 'Offering Three Cups', which followed the same procedure and pattern as performed in the initial sai, with group skits presented in between. Next came a nuo-exorcism ritual called 'Rinsing Off Plagues' (chongwen 沖瘟). This ritual was fairly simple in form but quite engaging. In the beginning, a miniature 'plague boat' (wenchuan 瘟船) made of paper was brought in and placed on firewood in front of the Incense Pavilion. Then, the Chief Master of Ceremonials recited 'the Writ of Exorcising Evil Spirits' (Quxie wen 驅邪文). While he was reciting the text, a ritual attendant set fire to the paper boat under the watchful eye of the Chief Master of Ceremonials. After that, a boy and a girl, about five or six years old, were brought in by their respective fathers. With their child held firmly on the chest, they jumped over the flaming boat in the presence of a large crowd of spectators, who reacted with a hearty round of applause. The ritual of 'Rinsing Off Plagues' is an ancient form of nuo exorcism performed during the temple festival to cleanse the community of evil spirits and epidemic diseases, and this is also the case with Dancing Jianzhai and A Monkey Extracted from Its Shell, both of which are key pieces in the repertoire of local Nuo theatre (nuoxi 儺戲) (Du 2016).

The final sai then proceeded to 'Beating the Drum of the Supreme Peace' (da taipinggu 打太平鼓), which was presented in front of the Incense Pavilion by a troupe of drummers from the Assembly of Eight Sounds to pray for peace and prosperity. Following the drum music was 'Offering Sacrifices to the Wind' (jifeng 祭風), which was performed in each of the four corners of the village, starting clockwise from the eastern corner. The ritual involved erecting an altar (Figure 56), offering incense, kowtowing and reciting sacrificial texts (jiwen 祭文) (Figure 57).

Among the various ritual, musical and theatrical performances for the final sai, the most important is 'Seeing Off the Deities According to Their Wishes' (Songshen dacai 送 神打彩). ${ }^{51}$ Similar to 'Inviting the Deities' and 'Welcoming the Deities', 'Seeing Off the Deities' is a grand procession, in which the gods and goddesses are carried in their sedan chairs, divine carriages or spirit tablets back to their own temples or shrines. Shortly after returning from offering sacrifices to the North Wind, the Chief Master of Ceremonials took a bunch of burning incense sticks from an Incense Master, inserted it in the burner in front of the Incense Pavilion, knelt down and kowtowed three times together with the three other ritual leaders. He then rose to his feet to chant the 'Writ of Seeing Off the Deities' (Songshen wen 送神文), which contained a long list of the invited deities and of the divine blessings the local community had received from them (Figure 58). Following the chanting of the ritual text was 'Offering Three Cups'. A village elder was invited to say prayers of grateful thanks to the goddess and her invited deities (Figure 59). 


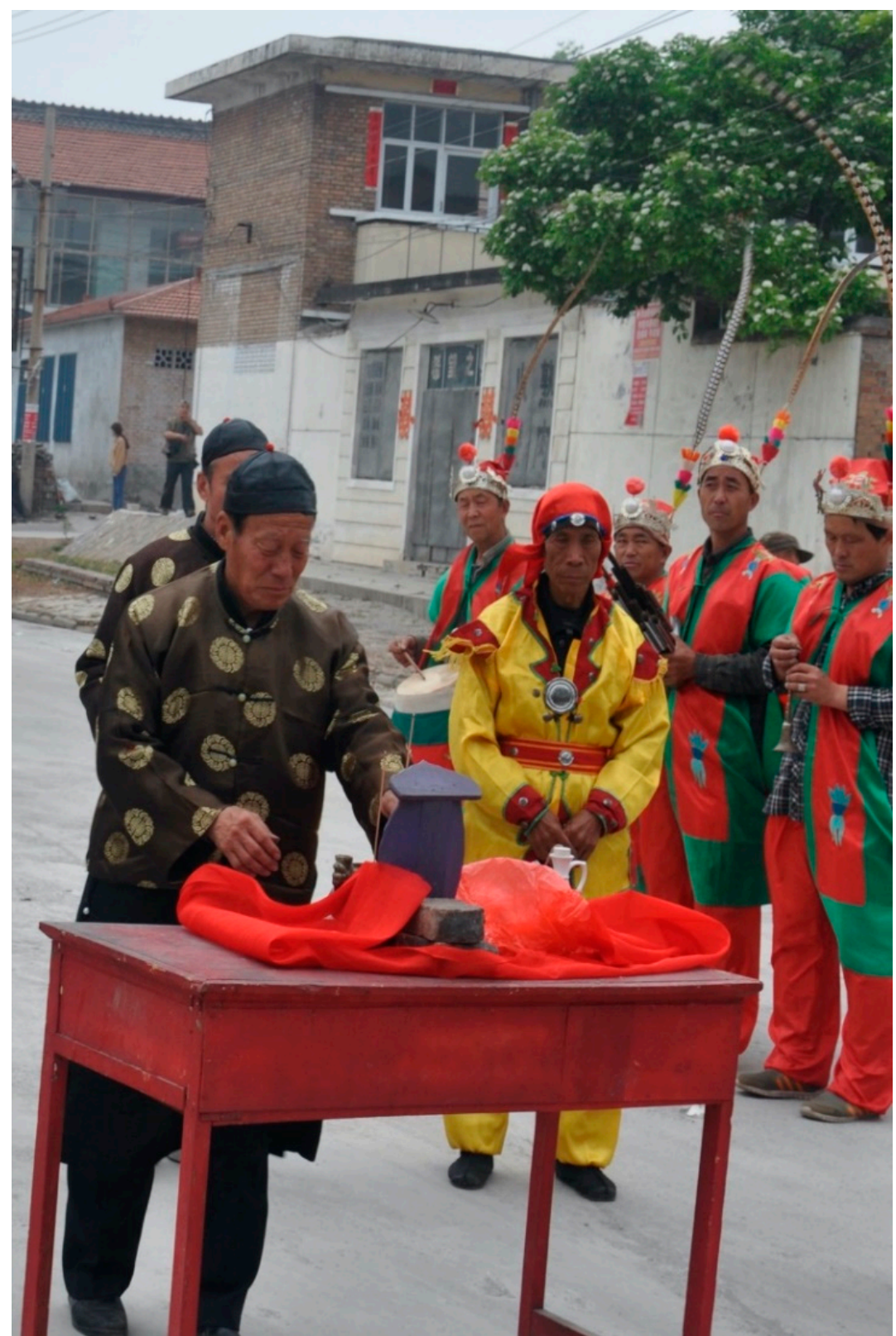

Figure 56. An Altar Is Set Up for the Ritual of Offering Sacrifices to Wind.

Wang Jinzhi then led all Entertainers from the Assembly of Eight Sounds to perform a music and dance to honour the gods and goddess, and after that, they walked up one by one to make a deep obeisance in thanksgiving for their divine grace. With the (sedan chairs, divine carriages and spirit tablets of) invited deities being carried back to their home shrines and temples, the final sai came to an end. 


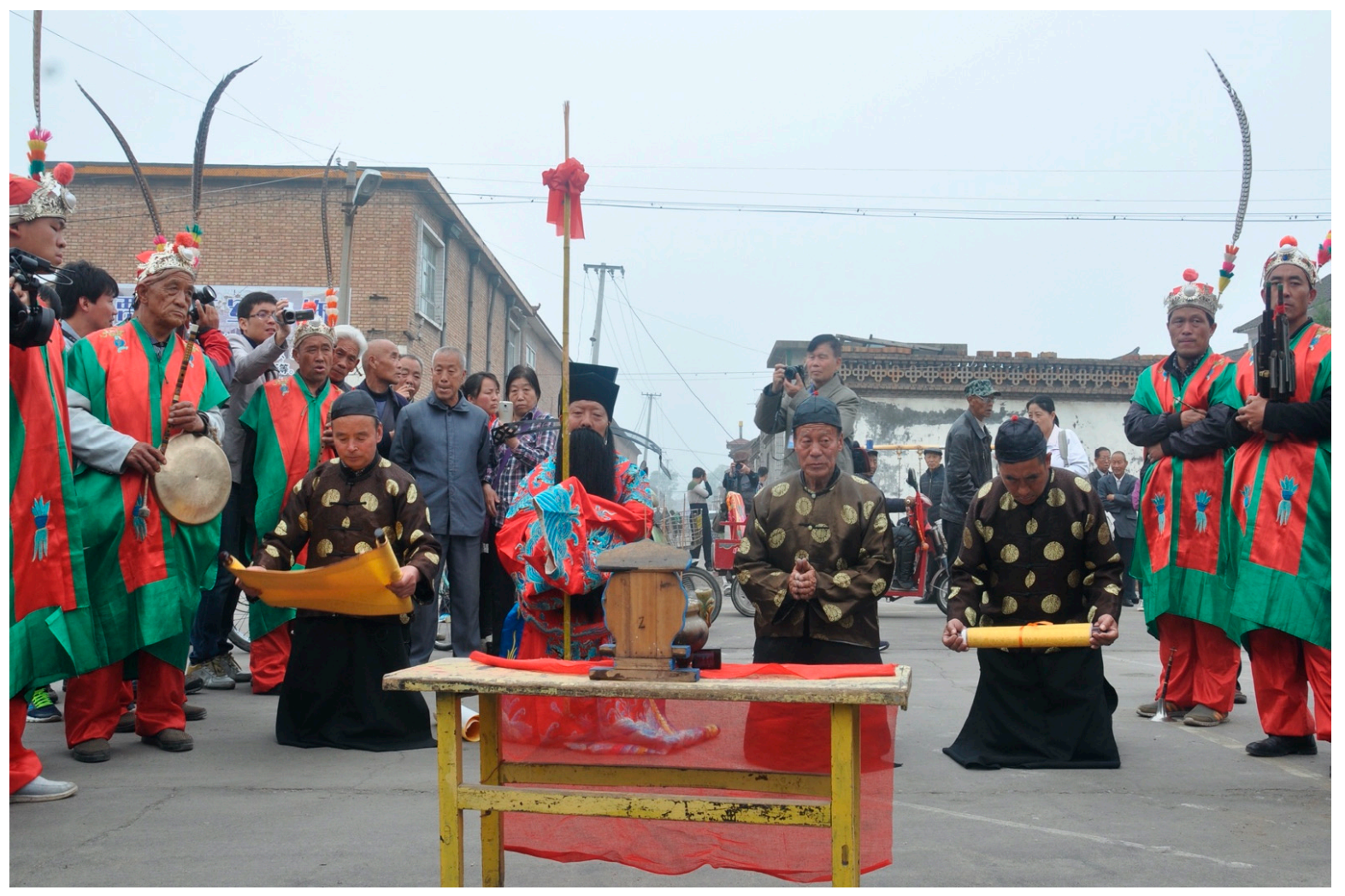

Figure 57. Offering Sacrifices to Wind.

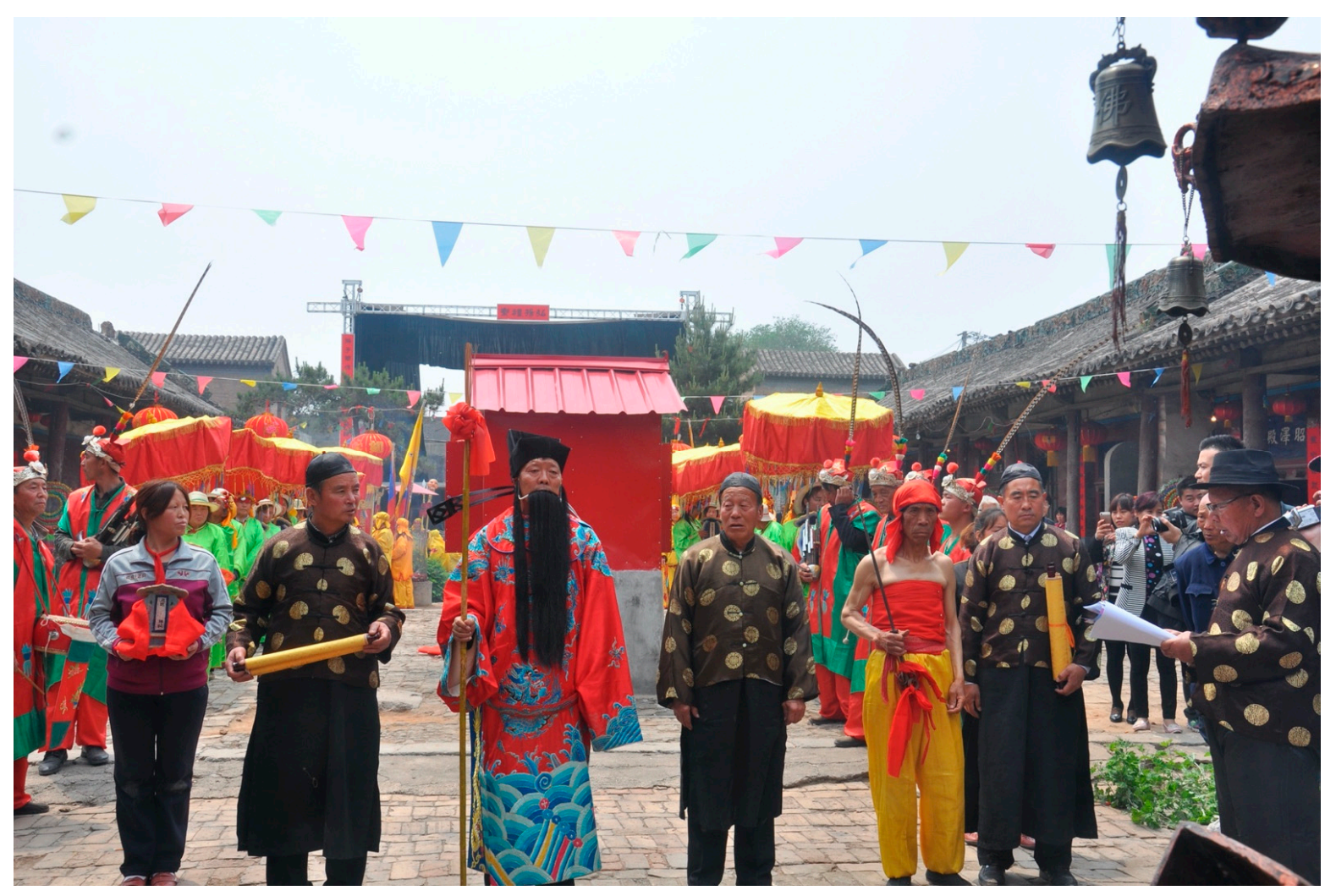

Figure 58. The Chief Master of Ceremonials Chants the 'Writ of Seeing Off Deities'. 


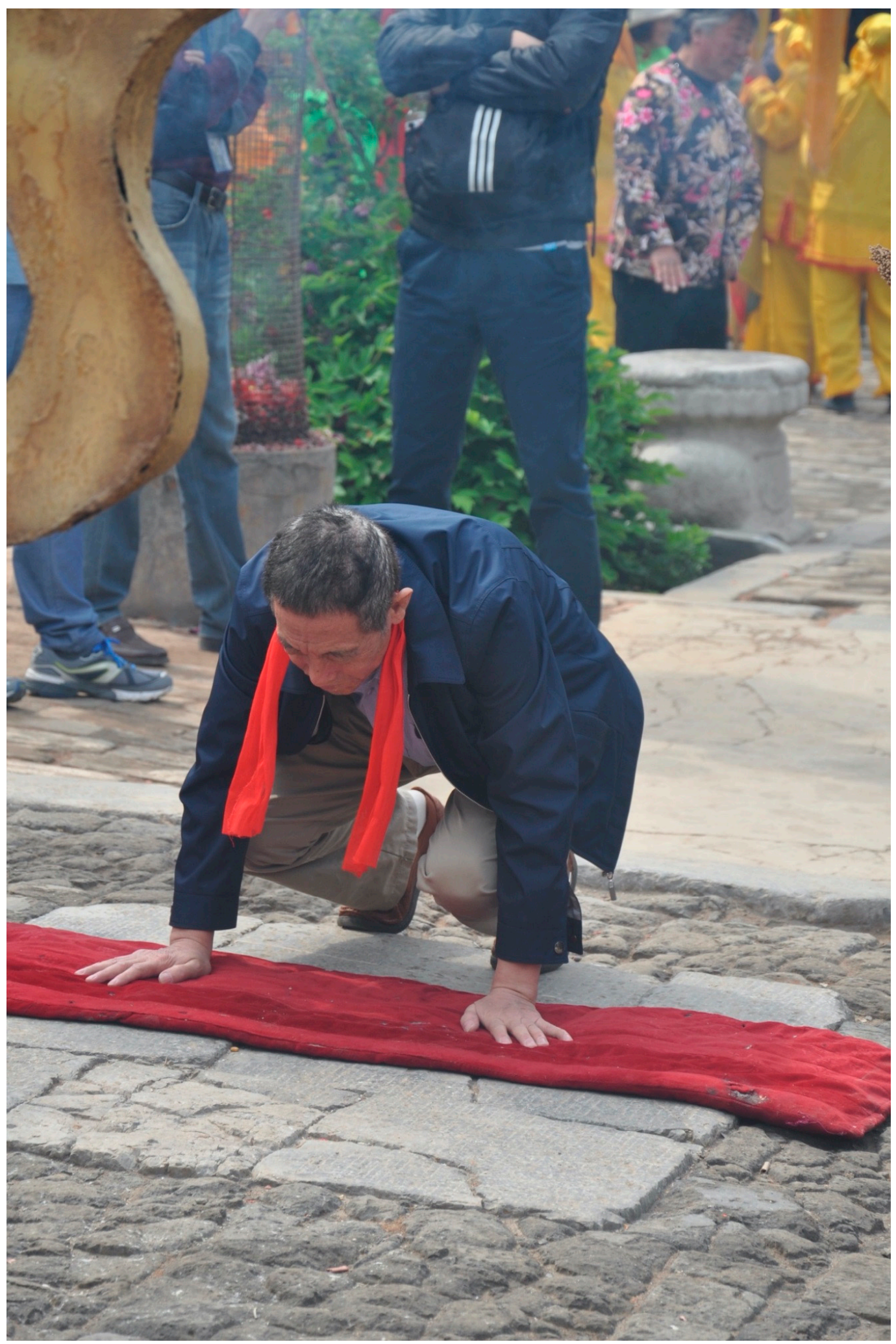

Figure 59. Village Elder Kneels Down to Kowtow.

\section{Coda to the Sai: A Special Concert}

The Double-Fourth Temple Festival continued to be celebrated on the morning of the third day (11 May) with a special concert of traditional folk and ritual music prevalent in the Shangdang region for centuries. This was an open-air concert held in the courtyard before 
the main hall of the Bixia Temple. Starting at 8:30 a.m. with the lighting of firecrackers, the concert was presented as a stand-alone instrumental performance open to all (Figure 60).

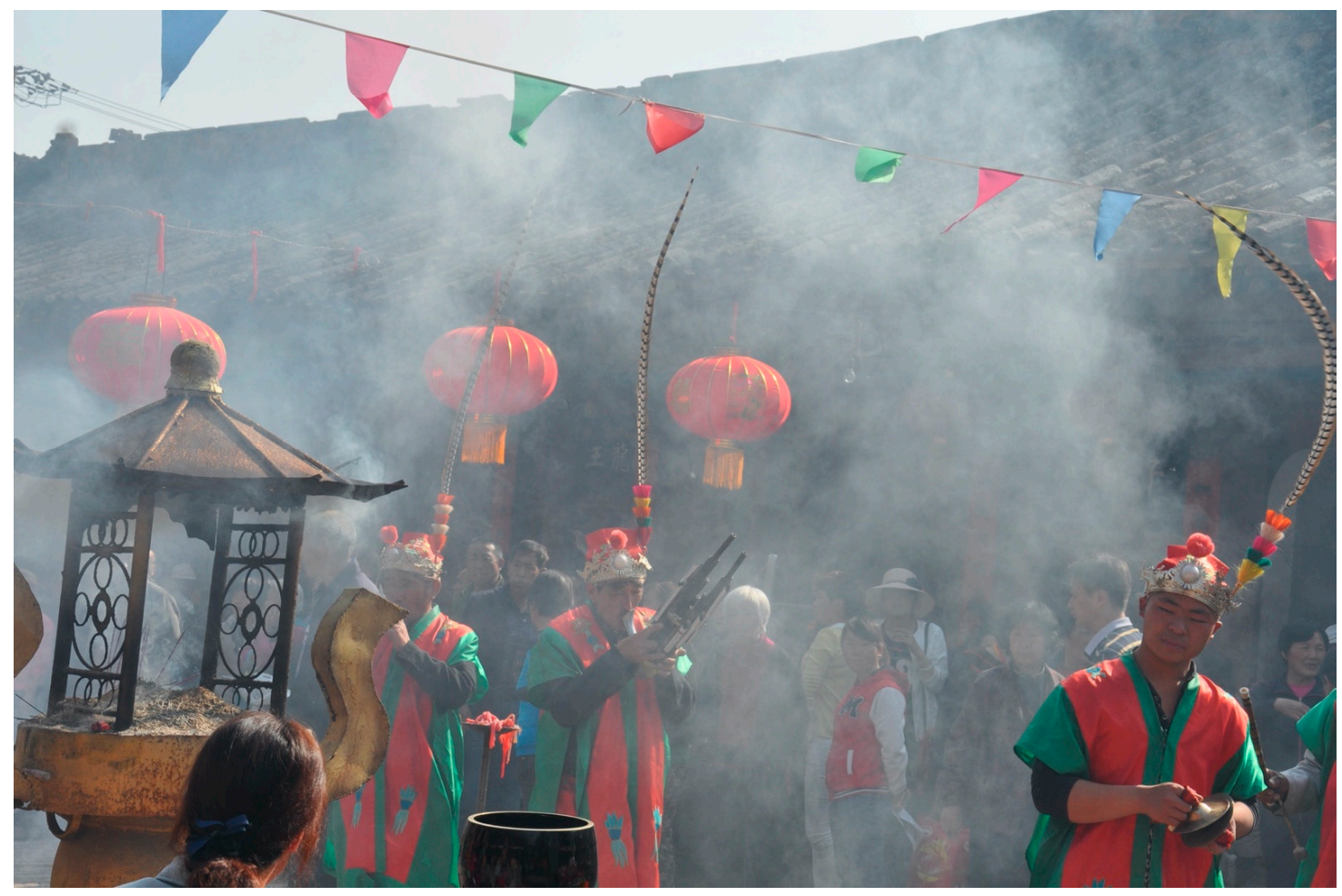

Figure 60. The Concert Opens with Firecrackers.

The musicians invited to give the concert remained from the Assembly of Eight Sounds, headed by Wang Jinzhi from Xiliu village. This small-scale concert consisted of two sessions devoted, respectively, to tune-title or named-song (qupai 曲牌) music and wind-instrument (chuizou 吹奏) music. The musical instruments come in two main categories, woodwind instruments and percussion instruments, the former including the suona, the sheng 笙 pipe, the bili 䇤策 pipe, the dizi flute and the bangzi 梆子 clapper, and the latter the drum, the luo 鑼 gong and the $b o$ 鈸 cymbal (Figure 61). Predominant among the instruments is the suona, which is widely used in a variety of rituals and festivals in northern China (Jones 2007).

The first session presented a variety of music from thirteen tune titles or melodic models, i.e., 'A Four-Clause Sentence' (Siju ju 四句句), 'Happy Dongdong' (Xi dongdong 喜咚咚), 'The Moon Over the Stern of a Boat on the Gu River' (Gushao yue 沽梢月), 'Old Sichuan Tune' (Lao Chuandiao 老川調), 'Worshipping the Drum' (Baigu 拜鼓), 'An Evergreen Goblet' (Changqing bei 長青杯), 'A Five-Flower Cup' (Wuhua zhan 五花盄), 'A Grand View of Lanterns' (Daguan deng 大觀燈), 'Joy for All Under Heaven' (Putian le 普天樂), 'Ten Thousand Years of Happiness' (Wannian huan 萬年歡), 'Enjoy Lotus Flowers' (Shang lianhua 賞蓮花), 'Five Blessings in Their Glory' (Wufu rong 五福榮) and 'A Tune on Flowers in Bloom' (Kaihua diao 開花調), which are at the core of the repertoire of the Assembly of Eight Sounds in the Shangdang region (Wang 2016a). They each consist of ten or more tunes or melodies. Some of these tune titles, such as Wannian huan and Putian le, have their origins in Tang and Song court music and Yuan and Ming operatic music, and some, such as Xi dongdong and Kaihua diao, in local folk music and mountain songs (shange 山 歌). Most of them have been incorporated into the music of the two popular forms of Shangdang theatre, Shangdang Clapper Opera (Shangdang bangzi) and Shangdang Lotus Opera (Shangdang laozi 上黨落子) (Wang 2016a). 


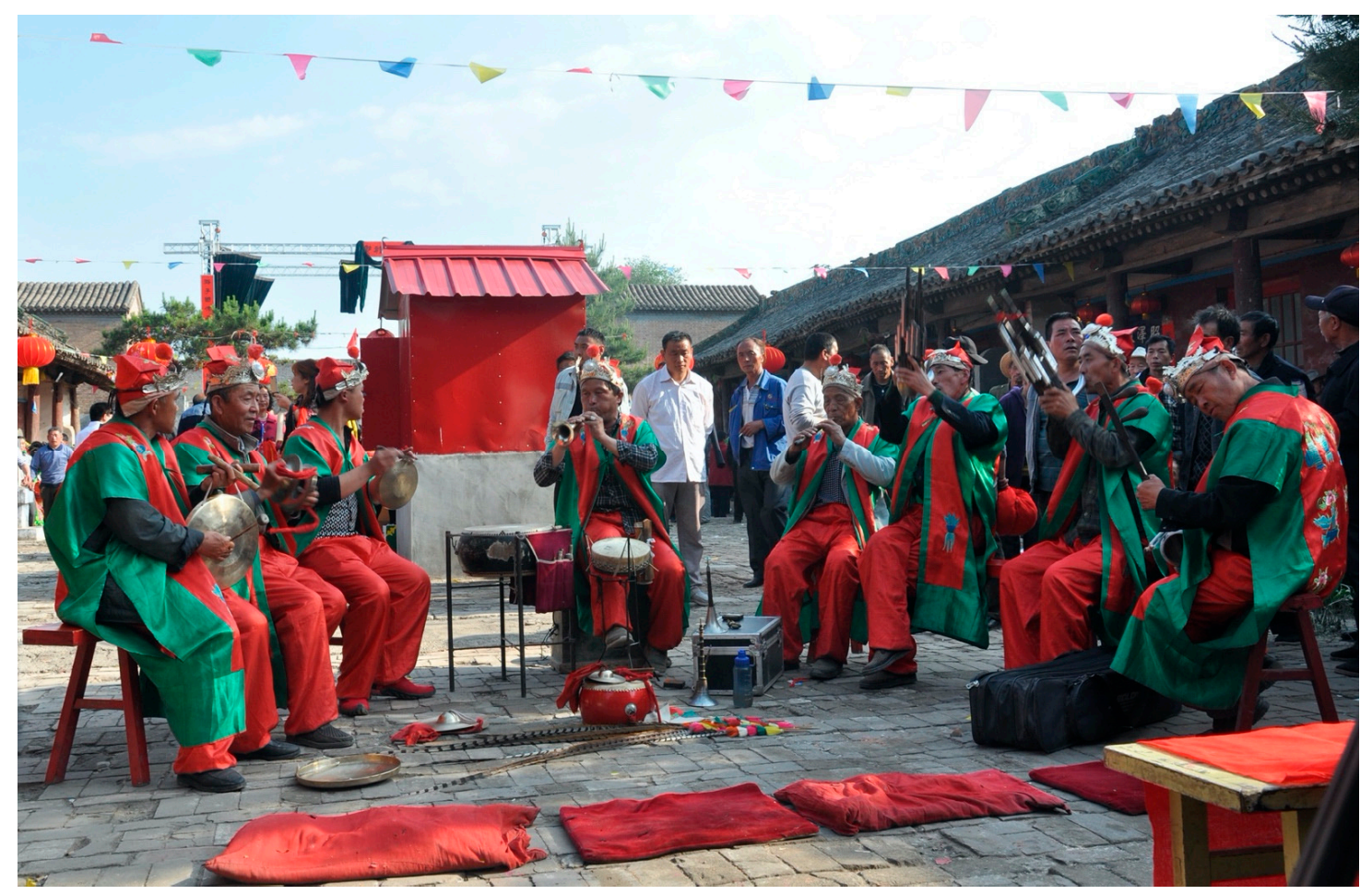

Figure 61. Eight Musicians from the Assembly of Eight Sounds.

The concert also provided a good opportunity for the musicians to demonstrate their technical skills in playing woodwind instruments. Presented in the second session were two pieces of operatic music from Shangdang Clapper Opera, The Crow Mountain (Wuya shan 鳥鴉山) and A Great Birthday Celebration (Da baishou 大拜壽), the former belonging to the style of chui 吹 and the latter to erhuang 二 in the musical system of Shangdang Clapper Opera. They both enjoy great popularity with locals, who have no difficulty seeing in their mind's eye scene change and stage performance through the changes in melody, tone, pitch, rhythm and timbre of the music (Wang 2016a). This type of musical performance is popularly known as chuixi 吹䖒because the woodwind instruments represented by the suona, when blown (chui 吹), produce sound images of theatrical performance ( $x i$ 戲) (Wang 2016a).

The concert ran from 8:30 a.m. until 12:00 p.m. at noon, with a 30-minute break between the first and second sessions. The concert attracted a great many people in the first place, and some of them came from neighbouring villages and towns. Having performed for three hours, the musicians all looked tired, but their faces lightened up instantly at a great roar of applause breaking out from the audience. The concert was over with the melody still lingering on the final note. A great wave of relief washed them over. I went up to Wang Jinzhi, asking whether I could have a picture with his troupe. 'Yes, of course, but please be quick. You know, we haven't had our lunch yet, and we have to get to Tunliu this afternoon to perform at a wedding ceremony this evening' (Wang 2016a). I noticed a small, weary, rueful smile crossing his face.

I gave a grateful bow to him. After the picture was taken, I saw him and his troupe off at the Divine Pool outside the Bixia Temple. I quickly engaged him in a conversation about Shangdang yuehu and his troupe. He spoke with a strong local accent about ten or more minutes, answering my questions, until a minibus came to pick them up. I waved goodbye to him, and then I walked back to the Bixia Temple only to find some people beginning to dismantle the structure of the Incense Pavilion and take down the paper and flower decorations from it. At the same time, I saw a female spirit medium (shenpo 神婆) performing séance in the courtyard (Figure 62) and some old village women queuing up to 
offer incense to the goddess in the sleeping hall with a shenpo singing and chanting inside (Figure 63).

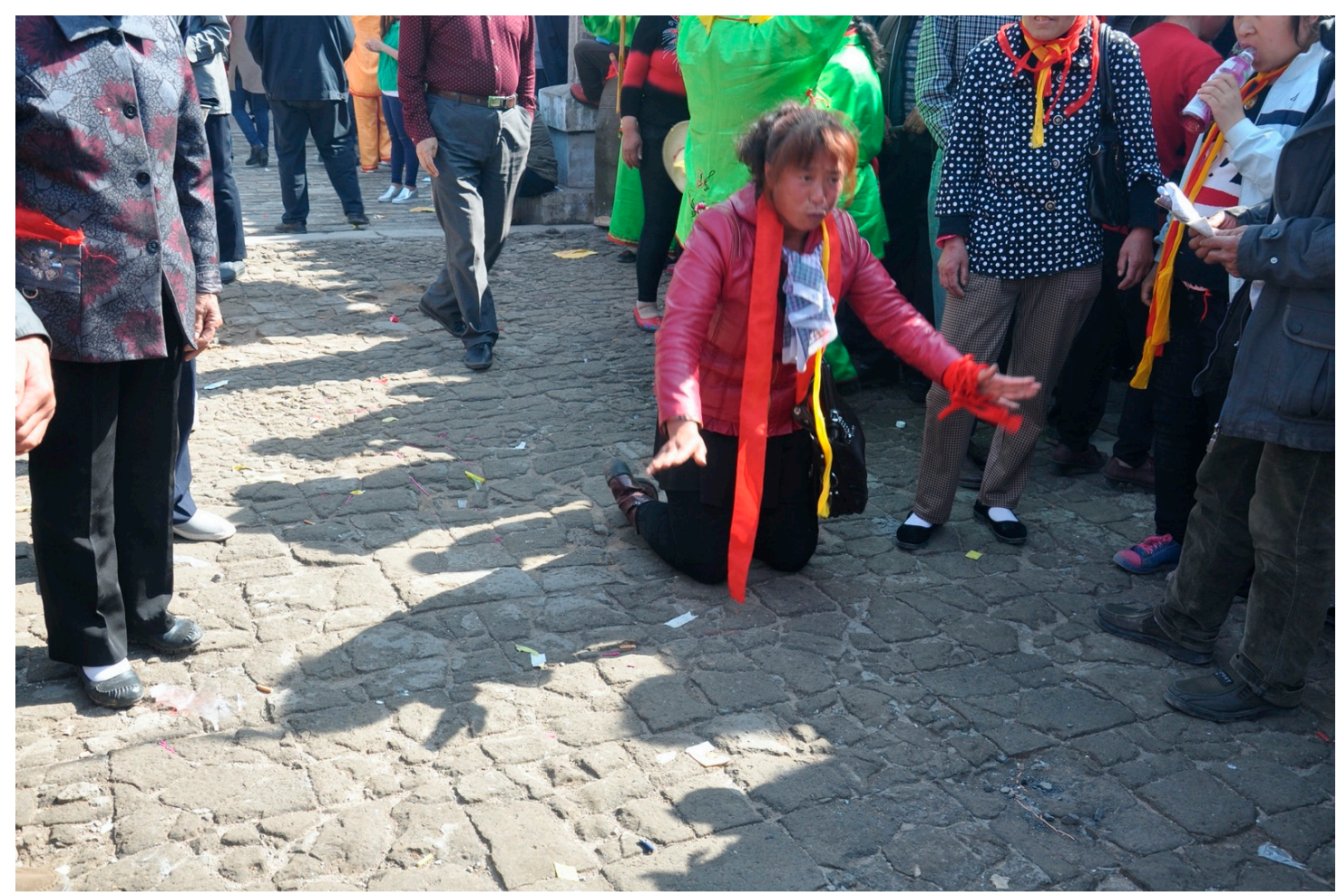

Figure 62. Female Medium Spirit Performs Séance in the Courtyard.

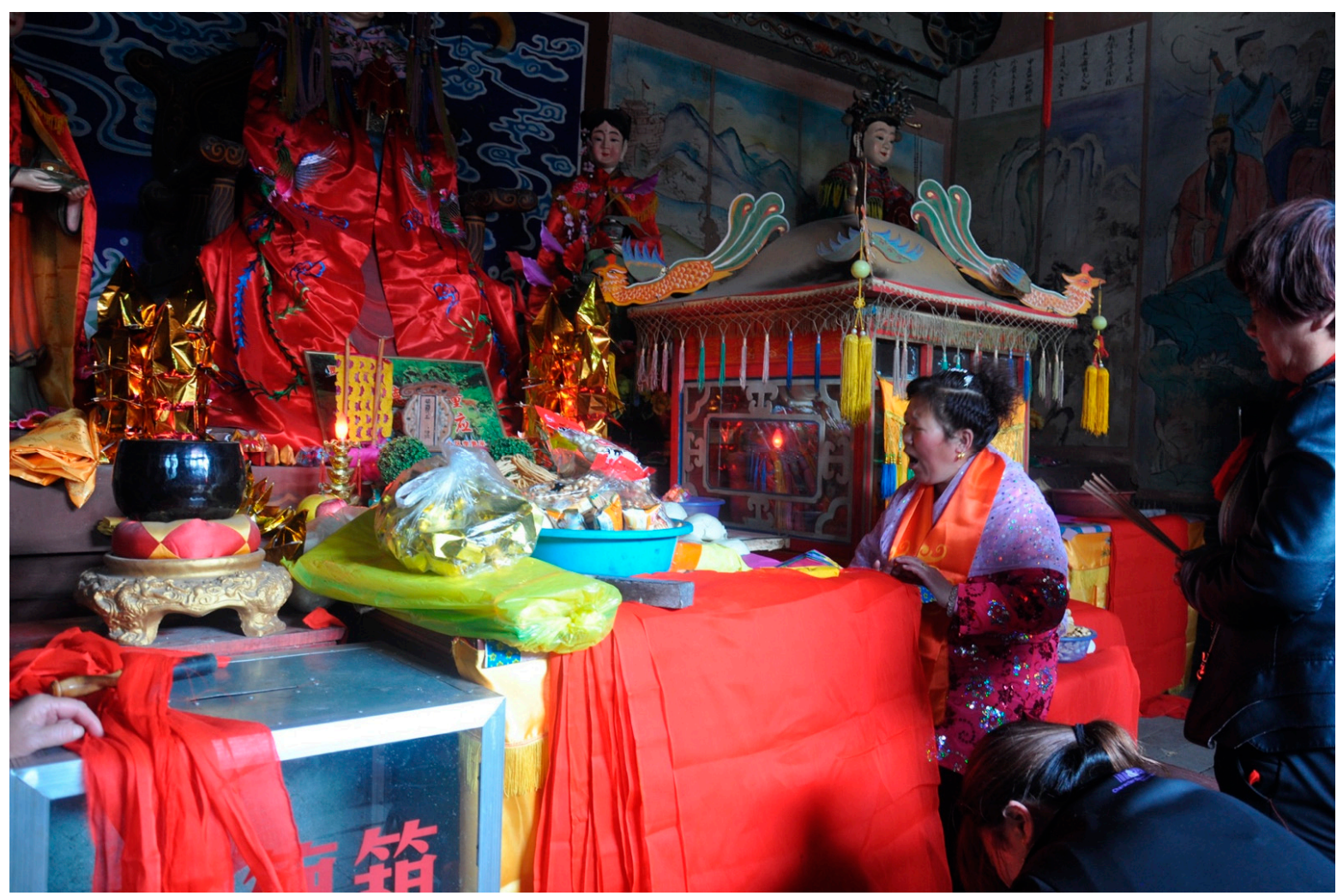

Figure 63. Female Medium Spirit Chants in Sleeping Hall. 
Now I realised that the Double-Fourth Temple Festival had eventually reached its end. After two and a half days of heightened celebrations, life was returning to normal in Jiacun, so was the functioning of the Bixia Temple.

\section{Conclusions}

This paper on Jiacun temples and temple festivals provides an eyewitness account of the sai ritual and xi performance presented in May 2016 during the Double-Fourth Temple Festival, covering a whole series of heightened activities of the 'number one folk shehuo in North China' - the standard tripartite saishe programme of welcoming, entertaining and seeing off deities in general and the dramatic shows on stage and street, grand processions of divine images and carriages, and sacrificial offerings of food, fruit and wine in every particular. Moreover, this paper also conducts a careful enquiry into the origins of saishe and the historical links of ritual and theatrical performance in Shangdang saishe with Song-Jin court ritual and variety show and an extensive survey of temples and shrines that house gods and goddesses in the Jiacun pantheon-together with a general introduction to saishe organisers and ritual specialists such as the Chief Community Head, Chief Master of Ceremonials, Masters of Ceremonials, Leader of Entertainers, Entertainers, Incense Elders, Ritual Chefs and Mapi, the spiritual medium, and their respective functions and responsibilities in the temple festival.

All this shows that Jiacun sheshuo is not simply a country funfair with loads of sideshows and roadside stalls but a deep-rooted, highly structured, sophisticated religious festival. The annual celebration in honour of the birthday of Bixia yuanjun, the principal deity of the Double-Fourth Temple Festival, which has come to represent the heart and soul of the social and spiritual life of Jiacun, presents to us a symbolic world of local religions at work in contemporary China-a world that is created through a dazzling array of deities and demigods and a series of seemingly seamlessly connected ritual and theatrical performances, demonstrating an elaborate structure and an exceptionally high level of sophistication that are on a par with and no less favourable a comparison to state and court rituals recorded in dynastic histories.

Widely known as the oldest surviving village festival in Shangdang, Jiacun shehuo retains more than any other village festival in southeastern Shanxi the form and function of court and country ritual and theatrical performances from the Song-Ming era that would have otherwise sunk into oblivion but for the rediscovery in the 1980s of the Ming-Qing liturgical texts. With an intriguing mixture of ritual performance and musical/theatrical entertainment, Jiacun village festival features a wide variety of traditional Chinese performing arts-from folk and ritual dance to dance drama, from mime to music, from farce skit to comedy sketch, from street performance to stage performance and from dramatic ritual to ritual drama to full-length historical drama. The festival allows us an opportunity to see how religious ritual is performed in association with music, dance and drama and how ritual, music, dance and drama interact and integrate with each other into a form of total theatre that involves masking; face painting; costuming; drumming; singing; speaking; chanting; dancing; miming; impersonating animals, immortals and human characters; and astounding displays of martial arts and acrobatics, for which xiqu is best known. The festival also allows us an opportunity to watch some early forms of Chinese theatre, such as duixi, zaju and yuanben, which had long been considered extinct, yet are found well preserved in the repertoire of Jiacun temple theatre.

The integration of various elements and various forms of Chinese theatre as we have seen in the festival are significant to research on Chinese theatre history, and particularly to the present study, which comes as part of the author's continuing efforts to explore the origins of Chinese theatre and examine the dynamic, interactive relationships between temple and theatre and between religious ritual and theatrical performance (e.g., Zhao 2019, 2020, 2022a, 2002b). Jiacun temple festival adds fresh evidence for the ritual origin of Chinese theatre, showcasing the pivotal role played by temple festival and temple theatre 
in the historical development of Chinese theatre from ritual to ritual drama and from ritual drama to drama.

Funding: This research was graciously funded by the One Hundred Talent Scheme of Shanxi Province (Shanxisheng bairen jihua 山西省百人計畫) 2015-2018.

Institutional Review Board Statement: Not applicable.

Informed Consent Statement: Not applicable.

Data Availability Statement: Not applicable.

Acknowledgments: I wish to express gratitude to Che Wenming, Du Tonghai, Duan Jianhong, Song Huaizhi, Song Yusheng, Wang Luwei, Wang Jinzhi and Wang Xuefeng, among others, for providing materials and assisting me in my fieldwork in Jiacun in 2016. I would also like to thank the three anonymous reviewers for their careful reading of the manuscript and offering their comments and suggestions.

Conflicts of Interest: The author declares no conflict of interest.

\section{Notes}

1 The earliest recorded reference to the biannual community ritual appears in 'Clearing Away the Grass' (Zaishan 載芝) and 'Good Ploughshares' (Liangsi 良䎤) in the section of 'Eulogies of Zhou' (Zhousong 周頌) of the Book of Songs (Shijing 詩經). These two poems are interpreted by Kong Yingda 孔穎達 (574-648) as referring, respectively, to 'spring prayer' (chunqi) and 'autumn thanksgiving' (qiubao) in his 'Introductory Note on “the Eulogies of Zhou” ' (Zhousong pu 周頌譜). For this note, see Maoshi (19.314).

2 The Mound of the Emperor of Locusts is a metonym for the Temple of the Locust Emperor (Huanghuang miao 蝗皇廟), which was built on a mound (gang 崗) northeast of Xiaotiangong 小天貢, a village about three kilometres south of Jiacun. The Eight Big Village Worship Associations was an alliance formed in the Ming dynasty (1368-1644) of village worship associations of Jiacun and eleven other villages including Xiaotiangong to worship Tang Taizong 唐太宗 (r. 628-649), who was deified and widely worshipped as a god of locusts in northern China. Tradition has it that the Emperor swallowed locusts, thus bringing to an end a locust plague that had wreaked havoc on crops in the capital area in 628 or the second year of Zhenguan 貞觀 (627-649), as recorded in the Essentials of Government during the Reign Period of Zhenguan (Zhenguan zhengyao 貞觀政要 8.2a).

3 Records of temple festivals held in Shangdang in the Song-Jin era are mostly found in epitaphs on tombstones and inscriptions on temple stone stelae. See, for example, 'Epitaph Inscribed on the Tombstone for Shi Shaozhong' (Shi Shaozhong beiwen 史 少中碑文), written by Zhao Bingwen 趙秉文 (1159-1232), a famous poet, scholar and court official of the Jin dynasty (Fushui ji 12. 3b-4a); see also Wang (2016b, pp. 39-67, esp. 45-46) for a highly informative discussion of the inscriptions on temple stone stelae dating from the Northern Song dynasty of the construction of theatre stages (wulou 舞樓, lit. 'dance tower') for the performance of musical dance (yuewu 樂舞) and variety show (zaxi 雜戲) during village temple festivals.

4 The 1997 re-enactment of the temple festival was staged and videoed as arranged by Changzhi City Bureau of Cultural Affairs for research and preservation purposes (Li 1997, cited in Wang and Wang 2007, p. 55). This is also the case with the 2006 re-enactment of the temple festival, which was held in association with the 'International Symposium on the Culture of Village Festivals and Hereditary Outcast Actor-Musicians', 11-15 August 2006. A total of sixty-three papers are included in the proceedings of the symposium (Ma and Liu 2006), but surprisingly, none of them are concerned with Jiacun temple festivals. For a detailed account of the two 'large-scale re-enactments of ancient temple festivals', see Du (2011a, pp. 112-166, 370-449).

5 The word 姜 in 姜城 is locally pronounced as kang rather than qiang as is normally pronounced.

6 Yuhuang 玉皇 or Yudi玉帝, abbreviated from the Great Jade Emperor (Yuhuang dadi 玉皇大帝), is widely worshipped as the ruler of Heaven and the Heavenly Court in Chinese popular religion and also as a supreme deity in Daoism.

$7 \quad$ All photos included in this paper were taken by the author.

8 The Palace of the Three Primordials is a temple dedicated to the Three Officers (sanguan 三官) in the Daoist pantheon一namely, the Officer of Heaven (Tianguan 天官), the Officer of Earth (Diguan 地官) and the Officer of Water (Shuiguan 水官).

9 The Three Great Bodhisattvas (sandashi 三大士) refer to Bodhisattva Avalokiteshvara (Guanyin pusa 觀音菩薩), Bodhisattva Samantabhadra (Puxian pusa 普賢菩薩) and Bodhisattva Manjushri (Wenshu pusa 文殊菩薩), respectively.

10 Here, Baiyi 白衣 is an acronym for Baiyi Guanyin 白衣觀音or White-Robed Guanyin, one of many manifestations of the bodhisattva Avalokiteshvara, which is closely associated with Child-Giving Guanyin (Songzi Guanyin 送子觀音) in Chinese Buddhism.

11 The Hall of the Cui Family, also known as the Shrine of Lord Cui (Cui fujun miao 崔府君廟), is not only a place for ancestor worship but also a Buddhist shrine called 'Ancient Hall of the Buddha' (Gu fotang 古佛堂), as recorded in the 'Stele Inscription of the Shrine of the Cui Family' (Cuixing jiamiao beiji 崔姓家廟碑記) (Du 2011b, p. 8). It must be pointed that Cui fujun, the 
ancestor of the Cui family in Jiacun, should not be confused with Cui Jue 崔玨, an early Tang dynasty official who was awarded the posthumous title of Cui fujun or Lord Cui after death and worshipped as a City God (Chenghuang 城隍) or an Infernal Judge (Panguan 判官) in Daoism and Chinese folk religion. For a hagiographical account of Cui Jue, see Sanjiao yuanliu soushen daquan (2.26b-27a).

12 The Bald-headed Grandma is the divine name (shenhao 神號) conferred on Baoshihua 寶石花, locally called Old Grandma Zhang (Zhangshi laonainai 張氏老奶奶, b. 1872), a virtuous woman who was deified after death in 1944 and worshipped as a patron god of women in Jiacun (Du 2016).

13 These small shrines are dedicated to the General of the Five Ways (Wudao jiangjun 五道將軍), who is described in Chinese ghostlore as a subdeity in the retinue of King Yama and the Lord of Mount Tai (Taishan fujun 泰山府君). For anecdotal and legendary accounts of the General of the Five Ways in pre-Tang records of the strange and supernatural (zhiguai 志怪), see Extensive Records of the Era of Supreme Peace (Taiping guangii 103.7b-8a, 103.10a-11a; 109.9b-11a; 297.5a-9b; 302.1a-5a; 304.2b; $329.3 b-5 b)$.

14 My comment on their preservation status is based on my fieldwork in Jiacun in May 2016.

15 In a fine-grained analysis of 'The Eight Immortals between Daoism and Popular Religion', Clart (2009, p. 86) correctly points out that the presence of the Eight Immortals as a group is clearly stronger in popular culture than in a Daoist context.

16 Renamed from Xuanwu in the fifth year (1012) of Dazhong xiangfu 大中祥符of the Song dynasty in order to avoid the imperial taboo on the word xuan 玄 (Yunlu manchao 9.243; Songshi 85.02097, 104.02541 and 146.03430), Zhenwu emerged as an anthropomorphic deity from a pre-Qin (221-206 BC) cult of the stellar God of North emblematised by a tortoise entwined with a snake and reached the peak of popularity in the Ming dynasty (1368-1644) when the warrior deity became one of the most widely worshipped gods in Daoism and Chinese popular religion as well (Chao 2011). Zhang Ban and Lu Ban are revered, respectively, by bamboo carpenters and wood carpenters as their respective patron gods.

18 The main entrance gate of a Buddhist/Daoist temple or monastery is conventionally referred to as shamen, which means literally 'mountain gate'.

19 The Three Sovereigns in Daoist mythology are the Sovereign of Heaven (Tianhuang 天皇), the Sovereign of Earth (Dihuang 地 皇) and the Sovereign of Humankind (Renhuang 人皇) (Baopuzi 4.37b, 4.42b-43a; Wushang biyao DZ1138: 25.3a-7b), who rule over vital force ( $q$ 氣), spirit (shen 神) and life (sheng 生), respectively (Wushang biyao DZ1138: 6.5b, cited in Steavu 2019, pp. 8-9).

20 Liuding 六丁 are a grouping of six female spirits of the ding stem (dinggan 丁干) in the system of heavenly stems and earthly branches (tiangan dizhi 天干地支), which is the yin counterpart of Liujia 六甲, a grouping of six male spirts of the yang jia-stem. The six ding days with which Liuding are associated are dingmao 丁卯, dingsi丁巳, dingwei 丁未, dingyou 丁四, dinghai 丁亥 and dingchou 丁卂丑, on which they descend from Heaven in response to prayers and summons from Daoist priests. While collectively referred to as the Divine General of the Six Yin (Liuyin shenjiang 六陰神將), the Jade Maiden of the Six Ding (Liuding yunü 六丁玉女) or the Envoy of the Six Ding (Liuding shizhe 六丁使者), they each have a name of their own named after the day of their descending to the world, hence the Jade Maiden of Dingmao 丁卯玉女, the Jade Maiden of Dingsi 丁巳玉女, the Jade Maiden of Dingwei 丁未玉女, the Jade Maiden of Dingyou 丁酉玉女, the Jade Maiden of Dinghai 丁亥玉女 and the Jade Maiden of Dingchou 丁丑玉女. For this note, see Baopuzi (3.34b-41b, 4.6a-7a), Dongshen badi miaojing jing (DZ640: 3b, 18a, 22a, 32a), Shangqing lingbao dafa (DZ1221: 2.17b-19a), Wushang biyao (DZ1138: 25.5a) and Qimen dunjia yuanji (1.15-17).

21 Sanzong refers to Hou Yi 后㹎, a god of archery who is described in the second-century philosophical work Huainanzi (18.118) as a hero who shot down nine suns on Mount Sanzong. The mountain lies about 25 kilometres northwest of the urban centre of present-day Tunliu, a county of Changzhi, which accounts for the sheer popularity of the Sanzong cult in the Shangdang region. For a brief discussion of folk beliefs in Sanzong and associated temple theatres in Shangdang, see Wang (2016b, pp. 278-88). See also Johnson (2009, pp. 235-301) for a detailed description of Sanzong temple festivals in Shangdang.

22 The shrine features a statue of the Lady of Eyesight (Yanguan niangniang 眼光娘娘). A popular goddess worshipped widely in northern China, the Lady of Eyesight is often portrayed as an acolyte or a manifestation of the Primordial Sovereign of the Morning Clouds, alongside the Lady Who Brings Children (Songzi niangniang 送子娘娘) in Daoist mythology (Peng 2006, p. 125).

23 The Horse King, also known as the Horse Marshal (Ma yuanshuai 馬元帥), the Numinous Horse Officer (Ma lingguan 馬靈官) or the Horse King Lord (Mawang ye 馬王爺), was one of the most widely worshipped deities in late imperial northern China. The god is frequently portrayed as being three-eyed in the iconography of Daoism and popular religion. For an insightful study of his cult in rural North China, see Shahar (2019).

24 See Note 20 above.

25 The shrine is dedicated to the King of Manifested Grace (Zhaoze wang 昭澤王), a noble title conferred by the Song court on a local deity surnamed Jiao 焦. Born in Changle 長樂 village, Wuxiang 武鄉 county of Shangdang Commandery in the ninth year (866) of Xiantong 咸通of the Tang dynasty (618-907), Jiao became an accomplished Daoist priest with supernatural power to summon wind and rain and suppress demons and devils and was deified and worshipped by locals as a dragon king after death. The deity was invested as Spirit Marquis (Linghou 靈侯) during the Tang dynasty and then as the Duke of Manifested Sagacity (Xiansheng gong 顯聖公) during the Five Dynasties (907-960), as recorded in the inscription—a rubbing of which was witnessed by the author of this paper in 2016 — on a stone stele erected in the eighth year (1869) of Tongzhi 同治 during the Qing dynasty 
(1644-1911) in the Travelling Palace on the Dragon Cave Mountain (Longdongshan xinggong 龍洞山行宮), a grotto shrine in Hanbei 韓北 township, Wuxiang county, where it is popularly known as the Cave of Dragon Jiao (Jiaolong dong 焦龍洞).

The word zisun 子孫 should not be understood literally as 'sons and grandsons' here. Rather, it is used to refer to small, private, hereditary (Daoist) monasteries, temples or shrines that have passed on to sons and grandsons as opposed to big, public monasteries, temples or shrines known as conglin 叢林 (lit. 'forests') or shifang conglin 十方叢林 (lit. 'forests of the ten directions'). Also called the Five Envoys of Epidemics (Wuwen shizhe 五瘟使者), they are Zhang Boyuan張元伯, the spring plague spirit; Liu Yuanda 劉元達, the summer plague spirit; Zhao Gongming 趙公明, the autumn plague spirit; Zhong Shigui 鍾士貴, the winter plague spirit; and Shi Wenye 史文業, the mid-year plague spirit and also the chief deity of the Five Plague Spirits. For this note, see Sanjiao yuanliu soushen daquan (4.42a).

28 The earliest performance of the fengshan rites recorded with a definite date were conducted by Ying Zheng 嬴政, the First Emperor of Qin (r. 247-210 BC) in 219 BC or the third year after he completed the conquest of all Chinese lands and founded the first unified empire of China. This record appears in the Records of the Grand Historian (Shiji 28. 1361-1365) by Sima Qian 司馬遷 (b. 149 BC), who also makes a mention of ancient (legendary) sage kings and rulers of the Shang (c. 1600-1046 BC) and Zhou (1045-256 BC) dynasties performing the rituals, although he does not provide any further detail except give Guan Zhong 管仲 (d. 645 BC), an eminent stateman of Qi 齊, as the source of information. On the state ceremonies of feng and shan in early China, see Chavannes (1910, pp. 158-353) and Lewis (1998).

The other four sacred mountains are: Mount Heng (Hengshan 衡山), or the Southern Peak in Hunan; Mount Hua (Huashan 華 山), or the Western Peak in Shaanxi; Mount Heng (Hengshan 恆山), or the Northern Peak in Shanxi: and Mount Song (Songshan 嵩山), or the Central Peak in Henan. On the five sacred mountains worshipped in the Daoist tradition and the development of their cult in late imperial China, see Reiter (2019) and Landt (1994).

30 On the Ten Kings of Hell in medieval Chinese Buddhism, see Teiser (1994). See also Sørensen (2017) for an informed description of the netherworld in medieval Daoist and Buddhist imagination.

31 In Chinese popular religion and literature, the Child-Giving Lady (Songzi niangniang 送子娘娘) refers to a grouping of three immortal sisters-namely, the Lady of the Cloud Firmament (Yunxiao niangniang 雲霄娘娘), the Lady of Emerald Firmament (Bixiao niangniang 碧霄娘娘) and the Lady of the Jade Firmament (Qiongxiao 瓊霄娘娘). In a sixteenth-century vernacular novel titled The Investiture of Gods (Fengshen yanyi 封神演義), for example, they are described as disciples of an accomplished warrior goddess called the Tortoise Spirt and Holy Mother (Guiling shengmu 龜靈聖母), who are invested by the Jade Emperor as 'the Lady of Childbirth' (Zhusheng niangniang 注生娘娘) in charge of human baby delivery and nursery after ascending to immortality.

32 The Daoist scriptures referred to throughout this study are all taken from the 1923-1926 Baiyunguan 白雲觀 version of the Zhengtong daozang 正統道藏 (Daoist Canon of the Zhengtong Reign Period), reprinted in 1977 by the Taibei-based Yiwen yinshuguan. Here, DZ stands for the Zhengtong daozang; the number following DZ is the sequential number of the text in the Schipper (1975) index to Zhengtong daozang; the first number after the colon is the juan number of the cited text; the number after the period is the page number in that juan, followed by ' $a$ ' and ' $b$ ' that refers to the recto and verso sides of the page, respectively. This precious scripture is dedicated to Jiutian yingyuan leisheng puhua tianzun 九天應元雷聲普化天尊, the most revered God of Thunder (Leishen 雷神) in the pantheon of the Divine-Firmament (Shenxiao 神霄) and Pure-Tenuity (Qingwei 清微) schools of Daoism.

34 For a brief introduction to 'The Twenty-Eight Lunar Mansions of China', see Kelley (1991).

35 Meng Yuanlao (fl. 1100-1150) offers a fairly detailed description of the ritual of offering cups performed in imperial banqueting in the Song dynasty in his Dream of Splendour of the Eastern Capital (Dongjing menghua lu 9.831-835). For an annotated English translation of Meng's record, see Idema and West (1982, pp. 48-56).

36 In the Formulary of the Correct Sounds of Supreme Harmony (Taihe zhengyin pu 1.90), the early Ming prince Zhu Quan 朱權 (1378-1448), a theatre enthusiast and a playwright himself, interprets yuan as 'guild' (hangyuan 行院) and yuanben as abbreviated from the longer phrase hangyuan zhi ben 行院之本, meaning 'scripts from the guild [of actors]', which is further interpreted by Wang [1915] (Wang [1915] 2007, p. 56) and Hu (1988, pp. 4-5; 2008, pp. 11-13) as texts from the guild of courtesans, entertainers, prostitutes, minstrels and beggars who made a living in entertainment quarters (wasi 瓦肆) in Song and Jin capital cities.

Attached to the 1574 Jiacun ritual text is a list of characters and spectacles (juese paichang dan 角色排) (Du 2011b, pp. 275-83: Han et al. 1987a, pp. 106-17). Included in it are twenty-five music and dance dramas, which are labelled as 'ya duixi' in the modern punctuated edition of the text by Han et al. (1987a, p. 106), who note that Cao Zhanbiao, from whom the text was collected, refers to these pieces as 'muted performance in processions' (yaba dui 啞巴隊, lit. 'muted group').

38 For a well-documented study of Mabi in folk beliefs and practices, particularly in rural North China, see Yao (2015). See also Zhang and Pu (1993, pp. 220-22) and Johnson (2009, pp. 51-53) for their descriptions of the liturgical role and performance of Mabi in Shanxi temple festivals.

39 Note the pun in the saying on the polysemous word sai 賽, which may mean 'competition' and 'offering sacrifices in gratitude to deities' as well. 
The Chinese word wangba is used here to refer to yuehu, a hereditary caste of actors and musicians who lived on playing ritual music, dance and drama in ceremonies and festivals. For book-length studies of yuehu in Shanxi, see Xiang (2001) and Qiao et al. (2002).

41 For a detailed description of the flowery display of offerings in Shangdang sai festivals, see Zhang (1993, pp. 239-41, cited in Johnson 1994, pp. 683-94).

42 All the writs (wen 文) referred to in this study are from the Collection of Prayer Textgs (Jiwenbu 祭文簿) compiled over a period from the late Qing to the early Republican era and included in the Huanghuanggang (Du 2011b, pp. 425-498).

43 The divine carriage is a wooden frame holding the clay statue of a dragon king attired in full dress regalia and carried by a man on shoulders.

44 Here, I follow Overmyer (2009, p. 97) in translating gushi as 'tableau', which is 'a scene from an opera represented on a small tray that is usually carried on frames fitted to the backs of men in a ritual procession'.

45 Qupo is an ancient form of musical entertainment. Its name is derived from the grand melody (daqu 大曲) prevalent during the Tang and Song dynasties. The third part of daqu is called po 破, which is sung and danced in accelerating tempo to music. For a brief discussion of the relationship between daqu and qupo and their performance in the Song dynasty, see Yang (1997b, pp. 146-52).

46 For an in-depth study of the religious and cultural history of the Guan Yu cult, see ter ter Haar (2017).

47 This court music officer, who was affiliated with the Section of Adjutants (canjun se 參軍色) of the Imperial Bureau of Court Entertainment (Jiaofang si 教坊司) of the Song dynasty, should not be confused with the role type (jiaose 腳色) of Adjutant (canjun) in Tang dynasty Adjutant plays (canjun xi 參軍戲). See Dolby (1988, pp. 13-15) for a brief discussion of the role type of canjun in Tang Adjutant plays.

48 Shangjing was located in modern Acheng 阿城, now a district of Harbin 哈爾濱, the capital of Heilongjiang province in Northeast China.

49 The Chinese words $k e$ 殼 and jia 甲, both meaning 'shell', are synonymous and interchangeable with each other.

50 For a discussion of the historical value of this ritual text, see Han et al. (1991b).

51 The Chinese word dacai 打彩 is commonly used to refer to audiences throwing (da 打) coins or other valuable things (cai 彩 or caitou 彩) to the stage as a reward or encouragement to an actor for their excellent performance, but here, this word is used to mean 'as the god wishes' (rushen suoyuan 如神所愿), according to the Chief Community Head (Du 2016).

\section{References}

\section{Primary Sources}

Baihu tong 白虎通. Ban Gu 班固 (AD 32-92). In Yingyin wenyuange Siku quanshu 景印文淵閣四庫全書 (Photographic Reproduction of the Wenyuan Pavilion Version of the Complete Books in the Four Treasures, hereafter SKQS). 1782. Rpt. in 1501 vols. Taibei: Shangwu Yinshuguan, 1983-1986.

Baopuzi neipian 抱朴子内篇. Ca. 330. Ge Hong 葛洪 (283-343). SKQS.

Chunqiu zuozhuan zhengyi 春秋左傳正義. Du Yu 杜預 (AD 222-284) comm. Kong Yingda 孔穎達 (574-648) sub-comm. In Ruan Yuan 阮 元 (1764-1849), ed. 1815. Shisanjing zhushu十三經注疏 (The Thirteen [Confucian] Classics with Commentaries and Sub-commentaries, hereafter SSJZS). Rpt. in 2 vols. Beijing: Zhonghua Shuju, 1980.

Daci haosheng jiutian weifang shengmu yuanjun lingying baoqian 大慈好生九天衛房聖母元君靈應寶籤. DZ 1300.

Dongjing menghua lu 東京夢華錄. ca. 1147. Meng Yuanlao 孟元老 (fl. 1100-1150). Yi Yongwen 伊永文 annot. $2^{\text {nd }}$ ed. in 2 vols. Beijing: Zhonghua Shuju, 2007.

Dongshen badi miaojing jing 洞神八帝妙精經. $6^{\text {th }}$ century AD78. DZ 640.

Foshuo Dizang pusa faxin yinyuan shiwang jing 佛説地藏菩薩發心因緣十王經. 2021. CBETA. Available online: https:/ / tripitaka.cbeta. $\mathrm{org} / \mathrm{en} /$ X01n0020 (accessed on 18 June 2021).

Fushui ji 滏水集. Zhao Bingwen 趙秉文 (1159-1232). SKQS.

Gaiyu congkao 陔餘叢考. Zhao Yi 趙翼 (1727-1814). SKQS.

Gongci 宮詞. Wang Jian 王建 (765-830). In Mao Jin 毛晉 (1599-1659) ed. Sanjia gongci 三家宮詞. SKQS.

Hanshu 漢書. Ban Gu 班固 (AD 32-92). Beijing: Zhonghua Shuju, 1997.

Huainanzi 淮南子. 1935. Liu An 劉安 (179-122 BC). In Zhuzi jicheng 諸子集成. Vol. 7. Rpt. in 8 vols. Beijing: Zhonghua Shuju, 2006.

Huanghuanggang Badashe Chaoben 蝗皇崗八大社抄本. Anonymous (fl. late Qing). A Person from the Li 李 Household (fl. 1928), hand-copy. Rpt. in Du Tonghai 杜同海, ed. 2011b. Shangdang saishe (xiace) 上黨賽社（下冊），425-98. Changsha: Hunan Ditu Chubanshe.

Jiaofang ji 教坊記. 714. Cui Lingqin 崔令欽 (fl. 713-741). In Zhongguo gudian xiqu lunzhu jicheng yi 中國古典戲曲論著集成 (一) (hereafter ZGXLJ), 1-30. Beijing: Zongguo Xiju Chubanshe, 1982.

Jingkang baishi jianzheng 靖康稗史箋証. Qu'an 确庵 (fl. 1164) and Nai'an 耐庵 (fl. ca. 1279), eds. Cui Wenyin 崔文印, annot. and collat. Beijing: Zhonghua Shuju, 1988.

Jiu Tangshu 舊唐書. Liu Xu 劉昫 (887-947) et al. Beijing: Zhonghua Shuju, 1997.

Jiutian yingyuan leisheng puhua tianzun yushu baojing 九天應元雷聲普化天尊玉樞寶經. DZ 16. 
Liji zhengyi 禮記正義. Zheng Xuan 鄭玄 (AD 127-200) comm. Kong Yingda (574-648) sub-comm. SSJZS.

Lingbao lingjiao jidu jinshu 靈寶領教濟度金書. Ning Quanzhen 甯全真 (1101-1181) comp. Lin Lingzhen 林靈真 (1239-1302) ed. DZ 466. Lunheng 論衡. Wang Chong 王充 (AD 27-ca. 97). SKQS.

Lüshi chunqiu 呂氏春秋. Lü Buwei 呂不韋 (d. 235 BC). Gao You 高誘 (fl. 205-212) comm. SKQS.

Maofeng zhenyin manlu 鄮真隱漫錄. Shi Hao 史浩 (1106-1194). SKQS.

Maoshi Zhengyi 毛詩正義. Mao Heng 毛亭 (fl. 206 BC) ed. Zheng Xuan comm. Kong Yingda sub-comm. SSJZS.

Nancun chuogeng lu jilu 《南村輟耕》 輯錄. Tao Zongyi 陶宗儀 (fl. 1348). In Yu Weimin 俞為民 and Sun Rongrong 孫蓉蓉, eds. 2006. Lidai quhua huibian: Tang Song Yuan bian 歷代曲話彙編 : 唐宋元編, 428-458. Hefei: Huangshan Shushe.

Nanzheng luhui 南征錄匯. Li Tianmin 李天民 (fl. ca. 1127). In Jingkang baishi jianzhu, 4.125-175.

Qimen dunjia 奇門遁甲元機. 1883. Yue Ke 岳珂 (1183-1243). In Tuibu zhuren 退補主人, ed. 1883. Qingyin shanfang congshu 清隱山房叢 書.

Rizhi lu 日知錄. Gu Yanwu 顧炎武 (1613-1682). SKQS.

Sanchoa beimeng huibian三朝北盟編. Xu Mengshen 徐夢莘 (1126-1207). SKQS.

Sanjiao yuanliu soushen daquan 三教源流搜神大全. 1935. Anonymous (fl. mid-14th century). Xiyuan 師園 (aka Ye Dehui 葉德輝, 1864-1927) ed. Changsha: Gushu Kanxingshe.

Shangqing Lingbao dafa 上清靈寶大法. Ning Quanzhen 甯全真 (1101-1181) and Wang Qizhen 王契真 (fl. 1180). DZ 1221.

Shiji 史記. Sima Qian 司馬遷 (b. 145 BC). Beijing: Zhonghua Shuju, 1997.

Shiji suoyin 史記索隱. Sima Zhen 司馬貞 (697-732). SKQS.

Shuowen jiezi 説文解字. Xu Shen 許慎 (fl. 1st century). Xu Xuan 徐鉉 (917-992) ed. SKQS.

Songshi 宋史. Toqto'a (Tuotuo 脱脱, 1314-1356) et al. Beijing: Zhonghua Shuju, 1997.

Taiping guangji 太平廣記. Li Fang 李昉 (925-996) et al., eds. SKQS.

Wenxian tongkao 文獻通考. Ma Duanlin 馬端臨 (1253-1323). SKQS.

Wushang biyao 無上祕要. Anonymous (fl. 571). DZ 1138.

Xihu laoren fansheng $l u$ 西湖老人繁盛錄. 1917. Anonymous (fl. ca. 1250). In Sun Yuxiu 孫每㐬修, ed. 1916-1921. Hanfenlou miji 涵芬樓秘笈 Ser. 3, 4-49. Rpt. ed. Taibei: Shangwu Yinshugan, 1967.

Yilin huikao 藝林匯考. Shen Zinan 沈自南 (jinshi 進士 1655). SKQS.

Yingshen saishe lijie chuanbu sishi qu gongdiao 迎神賽社禮節傳簿四十曲宮調. 1574. Cao Guozai 曹國宰 (fl. mid- to late Ming). hand-copy. Rpt. in Zhonghua Xiqu 中華戲曲 3: 1-50.

Yuanjun ji 元君記. Han Xizuo 韓錫胙 (1716-1776). In Ma Mingchu 馬銘初, ed. 1989. Taishan lidai wenshi cuibian 泰山代文史粹編, 376. Jinan: Shandong Youyi Shushe.

Yuefu zalu 樂府雜錄. Duan Anjie 段安節 (fl. 894). ZGXLJ.

Yunlu manchao 雲麓漫抄. Zhao Yanwei 趙彦衛 (jinshi 1163). In Wang Yunwu 王雲武, ed. 1935-1937. Congshu jichceng chubian 叢書集 成初編, Vol. 0297. Shanghai: Shangwu Yinshuguan.

Zhengtong daozang 正統道藏. ca. 1445. Rpt. in 61 vols. Taibei: Yiwen Yinshuguan, 1977.

Zhenguan zhengyao 貞觀政要. Wu Jing 吳競 (670-749). SKQS.

Zhou yuexing tu 周樂星圖. 1574. Cao Guozai (fl. mid- to late Ming), hand-copy. Rpt. in Du Tonghai, ed. 2011b. Shangdang saishe (xiace), 236-83. Changsha: Hunan Ditu Chubanshe.

\section{Secondary Sources}

Bruckermann, Charlotte. 2015. Trading on Tradition: Tourism, Ritual, and Capitalism in a Chinese Village. Modern China 42: 1-37. [CrossRef]

Chao, Fulin 晁福林. 1995. Shilun chunqiu shiqi de sheshen yu sheji 試論春秋時期的社神與社祭. Qilu Xuekan 齊魯學刊 2: 66-72.

Chao, Shin-yi. 2011. Daoist Ritual, State Religion, and Popular Practice: Zhenwu Worship from Song to Ming (960-1644). New York: Routledge.

Chavannes, Édouard. 1910. Le T'ai Chan: Essai de Monographie d'un Culte Chinois; Appendice le Dieu du sol Dans la Chine Antique. Paris: Earnest Leroux. Rpt., Taibei: Chengwen Chubanshe, 1970.

Clart, Philip. 2009. The Immortals between Daoism and Popular Religion: Evidence from a New Spirit-Written Scripture. In Foundations of Daoist Ritual: A Berlin Symposium. Edited by Florian C. Reiter. Wiesbaden: Harrassowitz Verlag, pp. 84-106.

Dolby, William. 1988. Early Chinese Plays and Theatre. In Chinese Theatre: From Its Origins to the Present Day. Edited by Colin Mackerras. Honolulu: University of Hawaii Press, pp. 7-31.

Dou, Kai 䆩楷. 1987. Shi lun “Ya duixi”試論「颔隊戲」. Zhonghua Xiqu 3: 168-78.

Du, Tonghai 杜同海, ed. 2011a. Shangdang Saishe (Shangce) 上黨賽社 (上冊). Changsha: Hunan Ditu Chubanshe.

Du, Tonghai, ed. 2011b. Shangdang Saishe (Xiace). Changsha: Hunan Ditu Chubanshe.

Du, Tonghai. 2016. Interview with Xiaohuan Zhao. Personal interview. Jiacun Village, Lucheng County, Changzhi City, Shanxi Province. May 8-10.

Fanzhou, Canghai 泛舟滄海. 2021. Bixia yuanju yu Jiutian shengmu yinhe huntong (yi)? 碧霞元君與九天聖母因何混同（一）. Zhongyuan Xinwenwang Changzhi Xinwen 中原新聞網長治新聞, June 30.

Feng, Junjie 馮俊杰, ed. 2000. Taihang Shenmiao ji Saishe Yanju Yanjiu 太行神廟及賽社演劇研究. Taibei: Minsu Quyi Congshu. 
Goossaert, Vincent. 2011. Dongyue dadi 東嶽大帝 (Great Emperor of the Eastern Peak). In The Routledge Encyclopedia of Taoism. Edited by Fabrizio Pregadio. Abingdon and New York: Routledge, vol. 1, A-L, pp. 377-80.

Guo, Cunting 郭存亭. 2020. Jiacun saishe: Guojia feiyi wenhua de “huo huashi” 賈村賽社：國家非遺文化的「活化石」. Wenhua Chanye 文化業 16: 51-56.

Gyss, Caroline. 2011. Bixia yuanju 碧霞元君 (Original Practices of the Jade Mist). In The Routledge Encyclopedia of Taoism. Edited by Fabrizio Pregadio. Abingdon and New York: Routledge, vol. 1, A-L, pp. 235-36.

Han, Sheng 韓聲, Shoutian Li 栗守田, Shuangxi Yuan 原雙喜, and Zhitan Chang 常之坦. 1987a. Yingshen saishe lijie chuanbu sishi qu gongdiao zhu shi 《迎神賽社禮節傳簿四十曲宮調》注釋. Zhonghua Xiqu 3: 51-117.

Han, Sheng, Shoutian Li, Shuangxi Yuan, and Zhitan Chang. 1987b. Yingshen saishe lijie chuanbu sishi qu gongdiao chutan 《迎神賽社禮 節傳簿四十曲宮調》初探. Zhonghua Xiqu 3: 118-36.

Han, Sheng, Shoutian Li, and Shuangxi Yuan. 1991a. Yingshen saishe jisi wenfan ji gongzhan qumu zhushi 《迎神賽社祭祀文範及供蓋曲 目》註釋. Zhonghua Xiqu 11: 1-62.

Han, Sheng, Shoutian Li, and Shuangxi Yuan. 1991b. Yingshen saishe jisi wenfan ji gongzhan qumu de shiliao jiazhi 《迎神賽社祭祀文範 及供葢曲目》的史料價值. Zhonghua Xiqu 11: 63-71.

Han, Sheng, Shoutian Li, and Shuangxi Yuan, eds. 1999. Shangdang Nuo Wenhua Yu Jisi Xiju 上黨儺文化與祭祀戲劇. Beijing: Zhongguo Xiju Chubanshe.

Han, Shuwei 韓樹偉. 1992. Shangdang duixi yu sai he nuo 上黨隊戲與賽和儺. Zhonghua Xiqu 12: 311-25.

$\mathrm{Hu}$, Ji 胡忌. 1988. “Yuanben” zhi gainian jiqi yanchu fengmao「院本」之概念及其演出風貌. Zhonghua Xiqu 8: 1-28.

$\mathrm{Hu}$, Ji. 2008. Song Jin Zaju Kao 宋金雜劇考. Rev. ed. Beijing: Zhonghua Shuju.

Huang, Zhusan 黃竹三. 1987. Woguo xiqu shiliao de zhongda faxian一Shanxi Lucheng Mingdai Lijie chuanbu kaoshu 我國戲曲史料的 重大發現—山西潞城明代《禮節傳簿》考述. Zhonghua Xiqu 3: 137-52.

Huang, Zhusan 黃竹三. 1998. Tan duixi 談隊戲. Minsu Quyi 民俗曲藝 115: 247-66.

Idema, Wilt, and Stephen West. 1982. Chinese Theater, 1100-1450: A Source Book. Wiesbaden: Franz Steiner.

Ji, Xiaoyan 季晓燕. 1998. Zhongguo gudai wunuo huohuashi-Nanfeng xiangnuo 中國古代巫儺活化石一南豐鄉儺. Wenshi Zhishi 文 史知識 1: 39-42.

Johnson, David. 1994. Temple Festivals in Southeastern Shanxi: The Sai of Nan-she Village and Big West Gate. Minsu Quyi 92: 641-734.

Johnson, David. 2009. Spectacle and Sacrifice: The Ritual Foundations of Village Life in North China. Cambridge: Harvard University Press.

Jones, Stephen. 2007. Ritual and Music of North China: Shawm Bands in Shanxi. Aldershot and Burlington: Ashgate.

Kelley, David B. 1991. The Twenty-Eight Lunar Mansions of China. Hamamatsu ika Daigaku Kiyō. Ippan Kyōiku 松科大紀要一般教育 5: 29-44.

Kleeman, Terry F. 1998. Sources for Religious Practice in Zitong: The Local Side of a National Cult. Cahiers D'Extrême-Asie 10: 341-55. [CrossRef]

Landt, Franke A. 1994. Die fünf Heiligen Berge Chinas: Ihre Bedeutung und Bewertung in der Ch'ing Dynastie. Berlin: Verlag Dr. Köster.

Lewis, Mark Edward. 1998. The Feng and Shan Sacrifices of Emperor Wu of the Han. In State and Court Ritual in China. Edited by Joseph P. McDermott. New York: Cambridge University Press, pp. 50-80.

Li, Junling 李俊領. 2018. Tianye diaocha suojian Huabei Bixia yuanjun xinyang de jige wenti 田野調查所見華北碧霞元君信仰的幾個問 題. Minsu Yanjiu 民俗研究 5: 60-66.

Li, Tiansheng 李天生. 1993a. Tang yuexing tu jiaozhu 《唐樂星圖》校注. Zhonghua Xiqu 13: 1-130.

Li, Tiansheng. 1993b. Saishe shikuang caifang jilu 賽社實況采訪記錄. Zhonghua Xiqu 13: 121-23.

Li, Tiansheng. 1993c. Nanshe Cao Manjin [aka Cao Zhan'ao] caifang ji 南舍曹滿金〔即曹占鰲〕采訪記. Zhonghua Xiqu 13: 124-25.

Li, Tiansheng. 1997. Hongyang chuantong wenhua wajue wenhua yichan一Woshi jiji yanjiu zhengli saishe wenhua 弘揚傳統文化挖掘 文化遺産——我市積極研究整理賽社文化. Changzhi ribao (Zhoumo Ban) 長治日報 (周末版), April 26.

Li, Tiansheng. 2016. Interview with Xiaohuan Zhao. Personal interview. Jiacun Village, Lucheng District, Changzhi City, Shanxi Province. May 8-9.

Mackerras, Colin. 2011. Tourism and Musical Performing Arts in China in the First Decade of the Twenty-first Century: A Personal View. CHINOPERL 30: 155-82. [CrossRef]

Ma, Guojun 馬國鈞, and Zhen Liu 劉禎, eds. 2006. Saishe Yu Yuehu Lunji 賽社與樂戶論集. Beijing: Zhongguo Xiju Chubanshe.

Okamoto, Saburō 岡本三郎. 1943. Taizan fukun no yurai ni tsuite 泰山府君由. Toyogaku Kenkyut 東洋學研究 1: 63-98.

Overmyer, Daniel L. 2009. Local Religion in North China in the Twentieth Century: The Structure and Organization of Community Rituals and Beliefs. Leiden: Brill.

Peng, Mulan 彭慕蘭 (aka Kenneth Pomeranz). 2006. Taishan nüshen xinyang zhong de quanli xingbie yu duoyuan wenhua 泰山 女神信仰中的權利、性別與多元文化'. In Zhongguo Dazhong Zongjiao 中國大衆宗教. Edited by Wei Sidi 韋思諦 (aka Stephen C. Averill). Nanjing: Jiangsu Renmin Chubanshe, pp. 115-24.

Pomeranz, Kenneth. 2007. Orthopraxy, Orthodoxy, and the Goddess(es) of Taishan. Modern China 33: 22-46. [CrossRef]

Qiao, Jian 喬健, Guanwen Liu 劉貫文, and Tiansheng Li. 2002. Yuehu: Tianye Diaocha Yu Lishi Zhuizong 樂戶：田野調查與歷史追蹤. Nanchang: Jiangxi Renmin Chubanshe.

Qu, Liuyi 曲六乙. 2006. Qianyan 前言. In Saishe Yu Yuehu Lunji 賽社與樂戶論集. Edited by Guojun Ma and Zhen Liu 劉禎. Beijing: Zhongguo Xiju Chubanshe. 
Reiter, Florian C. 2019. The Mountains in Daoist Religious Culture. Zeitschrift der Deutschen Morgenländischen Gesellschaft 169: 183-204. [CrossRef]

Schipper, Kristofer Marinus. 1975. Concordance du Tao-Tsang: Titres des Ouvrages. Paris: École Française d'Extrême-Orient.

Shahar, Meir. 2019. The Chinese Cult of the Horse King, Divine Protector of Equines. In Animals and Human Society in Asia: Historical, Cultural and Ethical Perspectives. Edited by Rotem Kowner, Guy Bar-Oz, Michal Biran, Meir Shahar and Gideon Shelach-Lavi. Cham: Springer International Publishing, pp. 335-90.

Song, Huaizhi 宋懷支. 2016a. Interview with Xiaohuan Zhao. Personal interview. Jiacun Village, Lucheng County, Changzhi City, Shanxi Province. May 9-10.

Song Yusheng 宋玉生. 2016b. Interview with Xiaohuan Zhao. Personal interview. Jiacun Village, Lucheng District, Changzhi City, Shanxi Province. May 9-10.

Sørensen, Henrik H. 2017. The Meeting of Daoist and Buddhist Spatial Imagination: The Construction of the Netherworld in Medieval China. In Locating Religions. Edited by Reinhold Glei and Nikolas Jaspert. Leiden: Brill, pp. 234-92.

Steavu, Dominic. 2019. The Writ of the Three Sovereigns: From Local Lore to Institutional Daoism. Hong Kong: The Chinese University of Hong Kong Press.

Tanaka, Issei 田仲一成. 1998. Chügoku Engekishi 中演劇史. Tokyo: Tokyo Daigaku Shuppankai.

Teiser, Stephen F. 1994. The Scripture on the Ten Kings and the Making of Purgatory in Medieval Chinese Buddhism. Honolulu: University of Hawaii Press.

ter Haar, Barend J. 2017. Guan Yu: The Religious Afterlife of a Failed Hero. Oxford: Oxford University Press.

Tian, Chengjun 田承軍. 2004. Bixia yuanjun yu bixia yuanjun miao 碧霞元君與碧霞元君廟. Shixue Yuekan 史學月刊 4: 80-87.

Wang, Guowei 王國維. 2007. Song Yuan xiqu shi 宋元戲曲史. Nanjing: Fenghuang. First published 1915.

Wang, Jinzhi 王進枝. 2016a. Interview with Xiaohuan Zhao. Personal interview. Jiacun Village, Lucheng County, Changzhi City, Shanxi Province. May 10-11.

Wang, Kui 王馗. 2006. Jujiao ‘Huabei diyi minjian shehuo' 聚焦「華北第一民間社火」.Zhongguo Wenhua Bao (Wenhua Yichan Zhuankan) 中國文化報（文化遺專刊），August 31 .

Wang, Luwei 王潞偉. 2016b. Shangdang Shenmiao Juchang 上黨神廟劇場研究. Beijing: Zhongguo Xiju Chubanshe.

Wang, Xuefeng 王學鋒. 2007. Jiacun Saishe Jiqi Xiju Huodong Yanjiu 賈村賽社及其戲劇活動研究. Ph.D. thesis, Chinese National Academy of Arts, Beijing, China.

Wang, Xuefeng. 2011. Dangdai Jiacun saishe huodong zhong de jisi xiju xingtai bianhua 當代賈村賽社活動中的祭祀戲劇型態變化. Jieri Yanjiu 節日研究 2: 78-92.

Wang, Xuefeng. 2012. Minjian Xinyang de Shehui Hudong: Shanxi Jiacun Saishe Jiqi Xiju Huodong 民間信仰的社會互動：山西賈村賽社及 其戲劇活動. Taibei: Xuesheng Shuju.

Wang, Xuefeng, and Kui Wang. 2007. Jisi xiju yu xinbian-Jindongnan Jiacun dangdai yingshen saishe yu xiju huodong ceji 祭祀、戲 劇與新變——互東南賈村迎神賽社與戲劇活動側記. Zhongguo Wenhua Huabao 中華文化畫報 4: 26-33.

Wang, Zhaoqian 王兆乾, and Guangqun Lü 呂光群. 2007. Zhongguo Nuowenhua 中國儺文化. Shantou: Shantou Daxue Chubanshe.

Xiang, Yang 項陽. 2001. Shanxi Yuehu Yanjiu 山西樂戶研究. Beijing: Wenwu Chubanshe.

Yang, Mengheng 楊孟衡. 1992. You “nuo" ru "sai" shuo 由「儺」入「賽」. Zhonghua Xiqu 12: 180-92.

Yang, Mengheng. 1997a. Shanxi saishe yuehu yinyangshi chuhu zhuanji 山西賽社樂戶陰陽師廚戶傳記. Minsu Quyi 107-108: 161-289.

Yang, Mengheng. 2000. Shangdang Gusai Xiejuan Shisi Zhong Jianzhu 《上黨古賽寫卷十四種》箋注. Taibei: Minsu Quyi Congshu.

Yang, Mengheng. 2006. Shangdang gusai yidian kao 上黨古賽儀典考. Minsu Quyi 151: 97-143.

Yang, Yinliu 楊蔭瀏. 1997b. Zhongguo Gudai Yinyue Shigao (Shangce) 中國古代音樂史稿 (上冊). Taibei: Dahong Tushu.

Yao, Chunmin 姚春敏. 2015. Minjian sheji zhong de “Mabi” chutan 民間社祭中的「馬裨」初探. Liaocheng Daxue Xuebao 聊城大學學報 2: 1-9.

Yao, Chunmin. 2019. Baipai yu richang: Fei wuzhi wenhua yichan shiyu xia de minjian saishe yishi tanwei-Yi Shanxi Shangdang Lucheng Jiacun Saishe yu Tangwangling shizhuansai weili 擺拍與日常 : 非物質文化遺産視閾下的民間賽社儀式探微——以山西 潞城賈村賽社與唐王嶺十轉賽為例. Zhongguo Wenhua Chanye Pinglun 中國文化産業評論 27: 446-60.

Ye, Tao 葉濤. 2007. Lun Bixia yuanjun xinyang de qiyuan 論碧霞元君信仰的起源. Minsu Yanjiu 3: 194-201.

Ye, Tao. 2009. Bixia yuanjun xinyang yu Huabei xiangcun shehui-Ming Qing shiqi Taishan xiangshe kaolun 碧霞元君信仰與華北鄉村 社會——明清時期泰山香社考論. Wenshizhe 文史哲 2: 24-37.

Yü, Ying-Shih. 1987. O Soul, Come Back! A Study in the Changing Conceptions of the Soul and Afterlife in Pre-Buddhist China. Harvard Journal of Asiatic Studies 47: 363-95. [CrossRef]

Zhang, Junhua 章軍華. 2014. Zhongguo Nuoxi Shi 中國儺戲史. Shanghai: Shanghai Daxue Chubanshe.

Zhang, Zhennan 張振南. 1993. Yueju yu sai 樂劇與賽. Zhonghua Xiqu 13: 230-59.

Zhang, Zhennan, and Haiyan Pu 暴海燕. 1993. Shangdang minjian de yingshen saishe 上黨民間的迎神賽社. Minsu Quyi 81: 209-30.

Zhang, Zhizhong 張之中. 1987. Duixi, yuanben yu zaju de xingqi 隊戲, 院本與雜劇的興起. Zhonghua Xiqu 3: $153-67$.

Zhao, Guoling 趙國藺. 1988. Saixi yuanliu qiantan ji qita 賽戲源流淺探及其他. Zhonghua Xiqu 6: 183-91.

Zhao, Shiyu 趙世瑜. 1999. Ming Qing Huabei de she yu shehuo-Guanyu diyuan zuzhi yishi biaoyan yiji erzhe de guanxi 明清華北的 社與社火——關於地緣組織、儀式表演以及二者的關係. Zhonguoshi Yanjiu 中國史研究 3: 134-42.

Zhao, Xiaohuan. 2019. Nuo Altar Theatre on a Liminal/Liminoid Continuum: Reflections on the Shamanic Origins of Chinese Theatre. TDR/The Drama Review 63: 57-77. [CrossRef] 
Zhao, Xiaohuan. 2020. Of Shrine and Stage: A Study of Huizhou Temple Theatre in Late Imperial China. In The Methuen Drama Handbook to Theatre History and Historiography. Edited by Claire Cochrane and Jo Robinson. London: Bloomsbury Methuen Drama, pp. 161-72.

Zhao, Xiaohuan. 2022a. Chinese Theatre: An Illustrated History through Nuoxi and Mulianxi, Volume One: From Exorcism to Entertainment. London and New York: Routledge.

Zhao, Xiaohuan. 2002b. Chinese Theatre: An Illustrated History through Nuoxi and Mulianxi, Volume Two: From Storytelling to Story-Acting. London and New York: Routledge.

Zhou, Huabin 周華斌. 2016. 'Shehuo' bian一Jianlun Zhongyuan chuantong shehuo de fasheng「社火」辨——兼論中原傳統社火的發 生. Zhonghua Xiqu 1: 1-13.

Zhu, Hengfu 朱恆夫. 2018. Shehuo yu saixi de xingcheng fazhan ji yishu xingtai 社火與賽戲的形成、發展及藝術形態. Xiqu Yu Suwenxue Yanjiu 戲曲與俗文學研究 2: 24-47. 